\title{
THE HORSES
}

ANTYQUITY, MIDULE AGES, AND KENAISSANCE, From the Earlieft Monuments down to the XVIth Century.

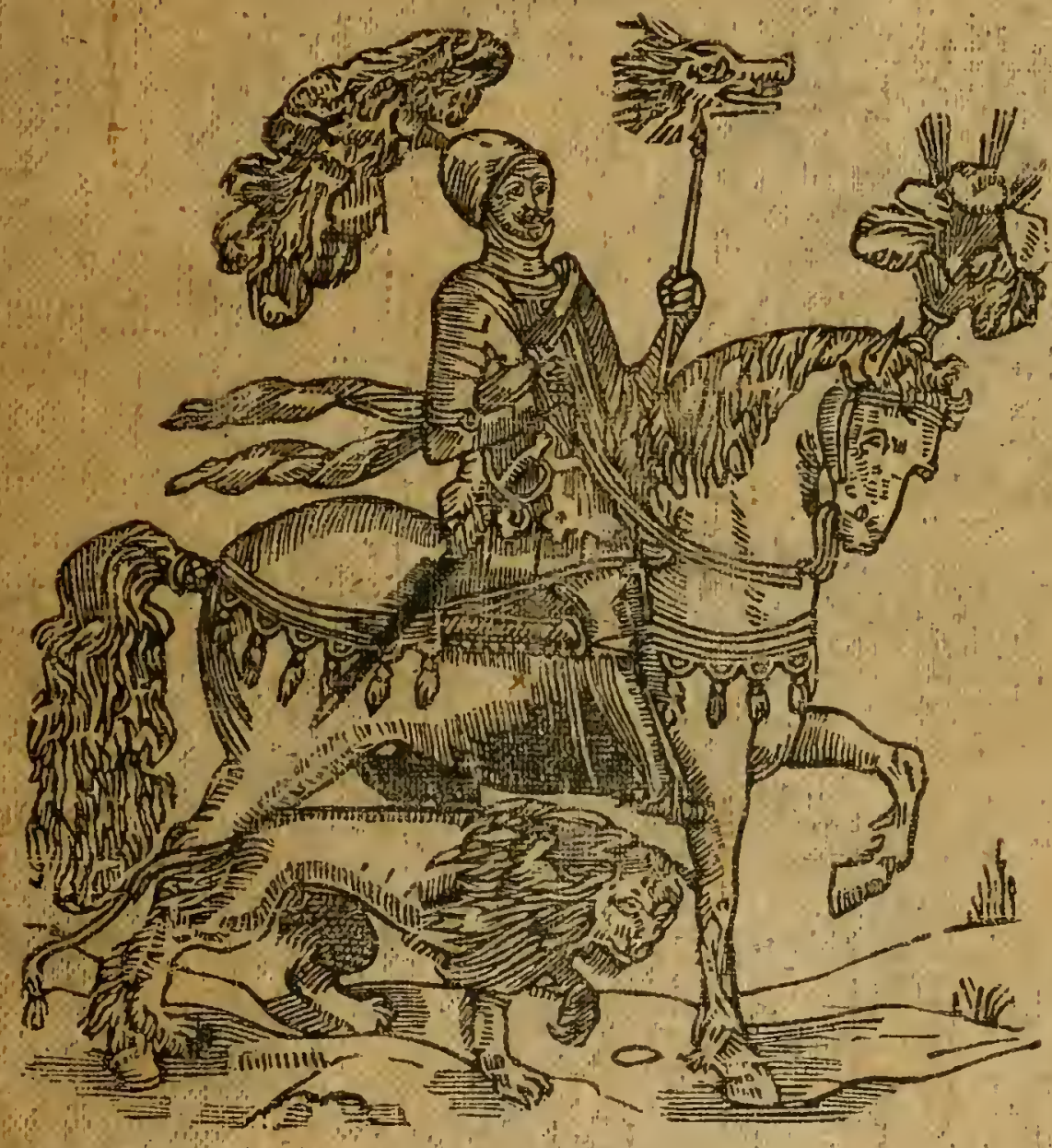

PH. CHARIES IBERJEAU, Autgor of Tar "qARIETSES or Dogs."

LONDON:

DULAU \& COO 37 SOHO SQUARE. 

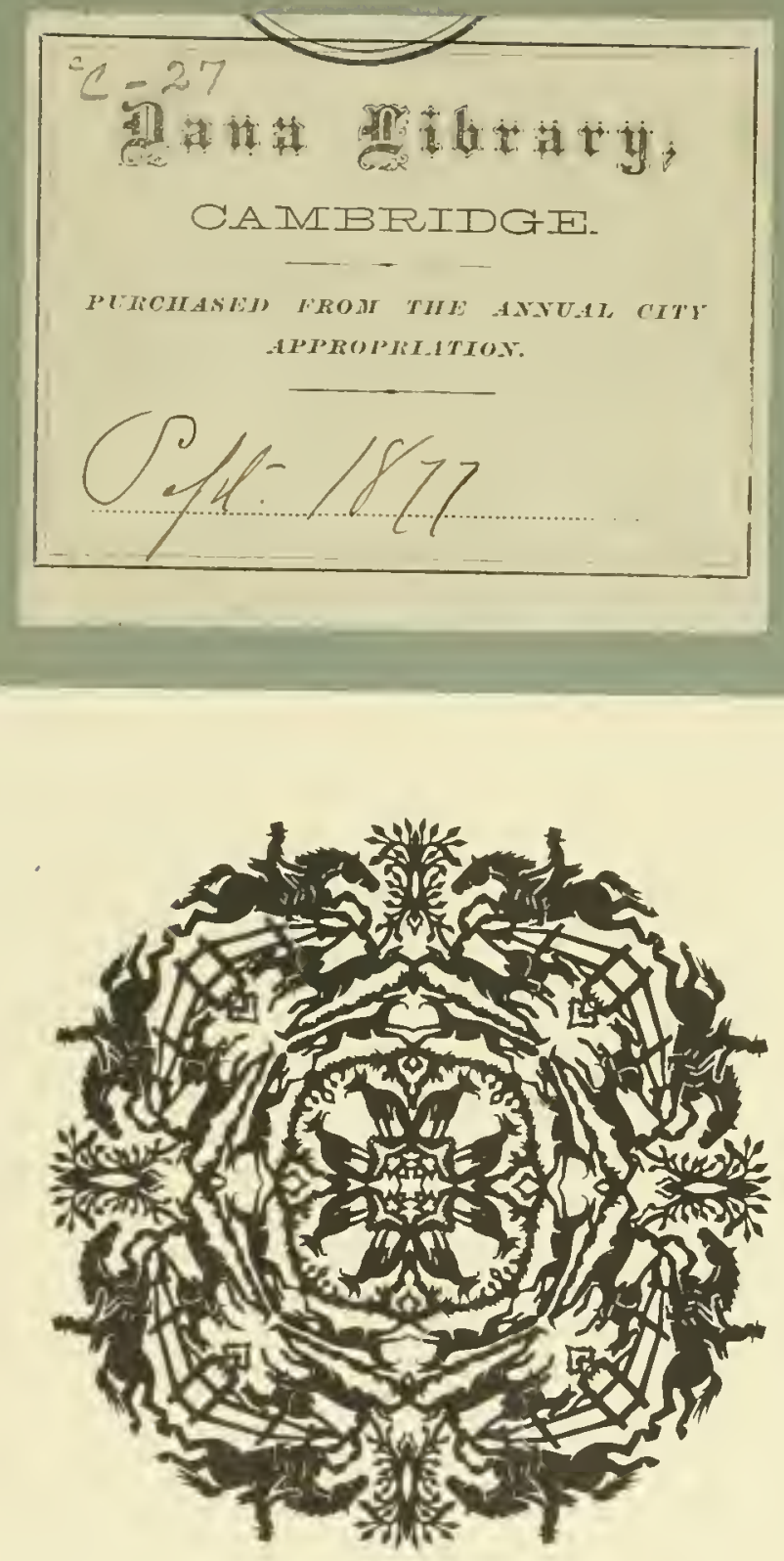

JOHN A.SEAVERNS 


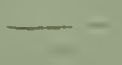

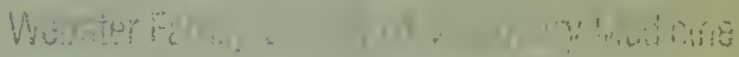

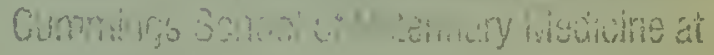
Tuts : nivesu 



\section{THE HORSES}

OF

\section{ANTIQUITY, MIDDLE AGES, AND RENAISSANCE,}

From the Earlieft Monuments down to the XVIth Century.

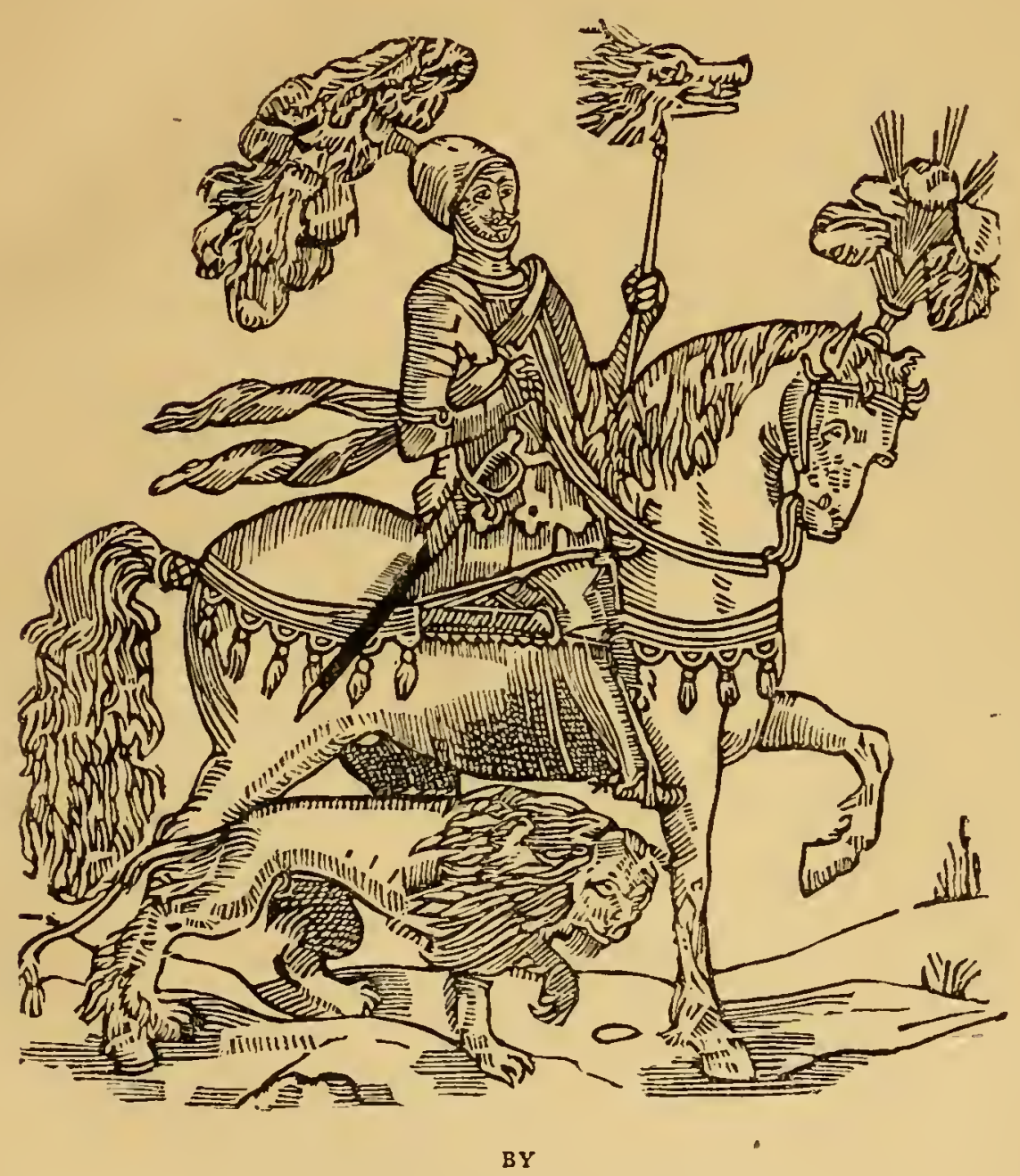

Ph. CHARLES BERJEAU, AUTHOR OF THE "VARIETIES OF DOGS."

\section{LONDON :}

DULAU \& CO. 37 SOHO SQUARE. 1864. 


\section{Golerm B7 \\ 5285 \\ B! \\ 1641}

LUNDON :

Printed by Strangeways \& Walden, 28 Cafte Street, Leicefter Square. 


\title{
CHARLES GEORGE PHILLIPS, ESQ.
}

\author{
This 2 book is Dedicated,
}



I.

Egyptian Horfe, Beit Oualley, Nubia. From the Sculptures at the Entrance of the Small Temple of Beit Oualley, near Ralabiche, Nubia.
Cheval égyptien, Beit Oualley, Nubie. Pris des fculptures à l'entrée du petit temple de Beit Oualley, près de Ralabfchc, Nubie.

II.

Egyptian Frefco-Painting, Thebes. From the Tomb of a Scribe of the Royal Wardrobe and Granaries, Weftern Hill of Thebes. Britifh Mufeum.

Chevaux égyptiens. Peinture fur frefque de Thèbes. Tombe d'un fcribe de la garde robe et des greniers royaux. Colline occidentale de Thèbes. Mufée britannique.

III.

Affyrian Bas-relief, Nimroud, 7th century, B.c. From the North-Weft Palace Nimroud. Erected by ATharakbal or Sardanapalus the Great (1ft). Britifh Mufeum.
Chevaux affyriens. Bas-relief de Nimrod, 7ème fiècle, A.c. Du palais nord-oueft de Nimrod. Elevé par Afharakbal ou Sardanapale le grand (ter). Murée britannique.

IV., V.

Affyrian Bas-relief, Afhurbanipal. Monuments of Sardanapalus III. 7 th century, B.c. Britifh Mufeum.
Chevaux affyriens. Bas-reliefs d'A Ahurbanipal. Monuments de Sardanapale III. 7ème fiècle, A.c. Mufée britannique.

VI.

Perfian Bas-relief of Perfepolis. From the Palace of the Forty Pillars (Chekel Minar).

Chevaux perfans. Bas-relief de Perfepolis. Du palais des 40 colonnes (Chekel Minar).

VII.

Perfian Bas-relief of Nakfhi Rouftam. From Sir J. Chevaux perfans. Bas-relief de Nakhi Rouftam. Ker Porter's Travels.

Voyages de Sir J. Ker Porter.

VIII.

Lycian Frieze of a Tomb. From the Acropolis. 6th century, B.c.

Cheval lycien. Frife d'un tombeau de l'Acropolis. 6ème fiècle, A.c. 
IX.

Lycian Frieze of a Tomb. From the Acropolis. Cheval lycien. Frife d'un tombean de l'Acropolis. 6th century, в.c. Gème fiècle, A.c.

X., XI.

Greek Frieze of the Parthenon. 5th century, B.c. Chevaux grecs. De la frife du Parthenon. jème fiècle, Britifh Mufeum. A.c. Mufée britannique.

XII.

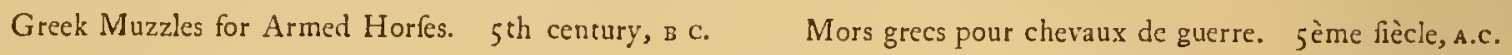
XIII., XIV., XV.

Etrufcan Painted Vafe. 4th century, в.c. Chevaux étrufques. Vafe peint du tème fiècle, A c.

XVI.

Greek Painted Vafe. 3 rd century, в.c.

Cheval grec. Vafe peint du zème fiècle, A.c.

XVII.

Sarmatian. From Trajan's column. Ift century, B.c.

Chevaux farmates. De la colonne trajane. ter fiècle, A.c.

XVIII.

Roman. From Trajan's Column. Ift century, B.c. Cheval romain. De la colonne trajane. I Ier fiècle, A.c.

XIX.

Roman Statue of Marcus Aurelius. 2nd century. Cheval romain. Statue de Marc Aurèle. zème fiècle.

$\mathrm{XX}$.

Byzantine Column of Theodofius. 5th century. Cheval byzantin. De la colonne de Theodofe. 5 c̀me fiècle.

XXI., XXII.

Norman. From the Bayeux Tapeftry. gth century. Chevaux normands. De la tapifferie de Bayeux. gème fiècle.

XXIII.

Spanith MS. of the 11 th century.

Cheval efpagnol. MS. du I ı̀me fiècle.

XXIV,

French. From the Abbey of St. Denis. 12th Chevaux francais. Vitraux de l'abbaye de St.-Denis. century. I zème fiècle. 
$\mathrm{XXV}$.

French. 1. Stained Glass, Cathedral of Chartres. 12 th century. 2 and 3 . French MS. 1 3 th century.
1. Chevalier francais. Verrière de la cathédrale de Chartres. 2 et 3 . Chaffeurs tirés d'un MS. francais du I j̇ème fiècle.

XXVI.

French MS. of the Apocalypfe. I $3^{\text {th }}$ century.

Cheval francais. MS. de l'A pocalypfe. I zème fiècle.

XXVII.

Englifh MS. 13th century.

Chevaux anglais. MS. du I ż̀̀me fiècle.

\section{XXVIII.}

Italian Frefco-painting. Campo Santo di Pila. 14th Chevaux italiens des frefques du Campo Santo de Pife. century. 1 4 ème fiècle.

\section{XXIX.}

Italian Frefco-Painting of the Campo Santo di Pifa. Cheval italien. Pcinture à frefque du Campo Santo I $4^{\text {th }}$ century. de Pife. 14 tème fiècle.

\section{$\mathrm{XXX}$.}

French. 1. Lancelot du lac, MS. 2. Roman de Chevaux français. 1. MS. de Lancelot du lac. 2. MS. Triftan MS. 1 $4^{\text {th }}$ century. du Roman de Triftan.

XXXI.

Englifh. Arthur of Little Eritain, MS. 14th century. Chevaux anglais. Arthur de la Petite Bretagne. MS. du I 4 ème fiècle.

XXXII.

French. Heures d'Anne de Bretagne, MS. 1 $5^{\text {th }}$ Cheval français. Heures d'Anne de Bretagne. MS. century. St. Martin dividing his Cloak with a Beggar. du 15 ème fiècle. St. Martin partageant_fon manteau avec un mendiant.

XXXIII.

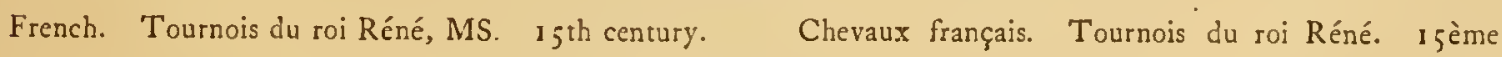
fiècle.

XXXIV.

1, 3. French MSS. 2. Seal of Charles le Téméraire. 15 th century.

1, 3. MSS. français, 2. Sccau de Charles le Téméraire. 15 ème fiècle.

XXXV.

Early Italian Mafters. I 5 th century. Maitres italiens du I 5 ème fic̀cle. 
XXXVI.

Horfe and Attendant. From the Roll of a Tourna-

Cheval et fon palefrenier. Tiré de la defcription ment, preferved in the College of Arms. This tourna- confervée au "Collége des Armoiries," d'un tournoi qui ment was reprefented in Weftminfter, the $13^{\text {th }}$ of eut lieu à Weftminfter le 13 fevrier, 1510-11.

February, $1510-11$.

XXXVII., XXXVIII.

German. From Lucas Cranach. I472-1553. Chevaux allemands, de Lucas Cranach. 1472-1553.

XXXIX.

German. Albert Dürer. 1505 .

Allemand. D’après Albert Dürer. 1505.

XL., XLI.

German. From Albert Dürer. 1471-1528.

Chevaux allemands. D'après Albert Dürer. 14711528.

XLII., XLIII., XLIV., XLV., XLVI.

German. H. Burgkmair. 1473-1529.

Chevaux allemands. D'après H. Burgkmair. 14731529.

XLVII., XLVIII., XLIX.

German. Hans Schauefein. 1490-1540.

Che vaux allemands. D'après Hans Schauefcin. 14901540.

L.

Englifh. From the Romance of Guy, Earl of Warwick. 16th century.

Anglais. Du roman de Guy, comte de Warwick. 16 ème fiècle.

LI., LII.

German. Hans Weigel. 16th century.

Allemand. D'après Hans Wcigel. I Gème fiècle.

LIII.

German Saddle and Stirrups. 16th century.

Allemand. Selle et étriers du i Gème fièclc.

LIV.

Dutch. Lucas van Leyden. 1516.

Hollandais. Lucas van Leyden. 1516.

LV.

German. Joft Amman. 1539-1591. From a print in the Britifh Mufeum.

Chevaux allemands, par Joft Amman. Gravure du Cabinet des Eftampes au Mufée britannique.

LVI.

Roman horfes. J. Stradanus. 16 th century. fiècle.

Chevaux romains, d'après Vam dcr Straat. I Gème 


\section{LVII.}

French. Francis I. From a painting by Janet. Cheval de François 1er. Peinture de Janet. 1515$15^{15-1560 .}$ 1560.

\section{LVIII.}

Theffalonian horfe. J. Van der Straat. 16th century. Cheval theffalonien, d'après Van der Straat. 16ème fiècle.

\section{LIX.}

Italian. Drawing by Leonardo da Vinci, in the Print Room of the Britifh Mufeum.

Têtes de chevaux italiens. Deffin de Léonard de Vinci, au Cabinet des Eftampes du Mufée britannique.

\section{LX.}

German horfes by Martin Zeifinger. From an etching in the Britilh Mufeum. 1501 .

Chevaux allemands, d'après une gravure du Mufée britannique, par Martin Zeiffinger. 1501.

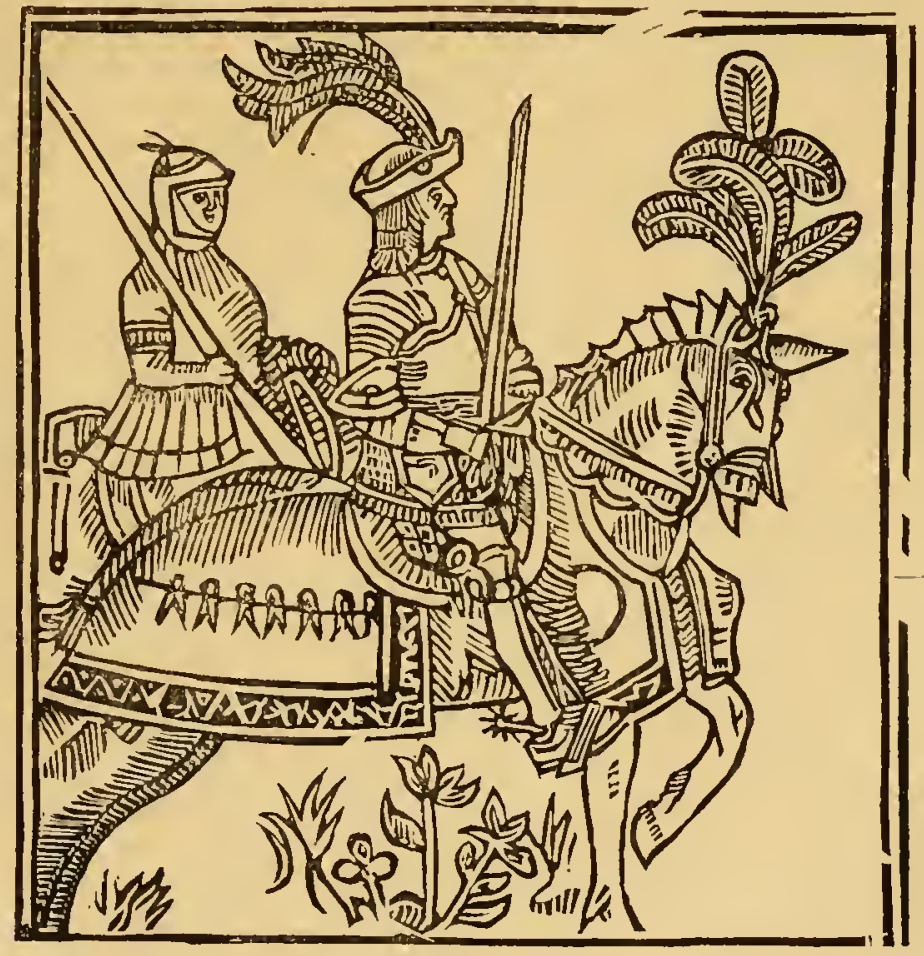





\section{HORSES.}

THE Horfe, like man, is indigenous to the high table-lands of Afia. From his original name, פרש, Paras, are derived the names of nations known only as horfemen, fuch as Perfians, Parthians, Parfis, and, perhaps, Prufians; and the onomatopœia "Prsfh" is ufed in every part of Europe ftill occupied by the Slavonic race to ftop the horfe in his movements. The flaming infcription feen at Belfhazzar's feaft announced to the doomed monarch the approach of his enemies, the Perfians, whofe name Hebrew copyifts miftook for Phares, when it was פישים, Parafim. The Germanic name of the horfe, Pferd, Perd, Paerd, may eafily be. traced to the original Paras, and the Slavonic onomatopeia Prsft. The Ethiopian Fars, the Arabian Feres, the Saxon Hors, have, as near as poffible, the fame etymology.

Through variations of habits, of climates, of temperature, the primary form of the horfe has been greatly modified, and a fimilar change, imperceptible but fure, is ftill proceeding from the fame caufes. The Egyptian horfe of the Delta in ancient times is more like a Dutch horfe of our days than his Afyrian contemporary. The reafon of this refemblance is, that the Egyptian horfe of the Delta treading, like the Netherlandifh horfe, on elaftic ground, in rich paftures, acquired a greater mufcular development, at the expenfe of the nervous fyftem, and became more fit to draw a heavy chariot with meafured ftep than to carry a horfeman, with the rapidity of an arrow, upon ftony or uneven ground. Such is probably the reafon why, in ancient pictures and monuments, an Egyptian warrior is never reprefented on horfeback, but always appears in a light war-chariot, drawn by feveral horfes. Of the Egyptian horfes of modern times, Bruce fays " that the figure they would make in point of fwiftnefs is very doubtful, their form being entirely different from that of the Arabian; but beautiful and fymmetrical parts, great fize and ftrength, the moft agile, nervous, and elaftic movements, great endurance of fatigue, docility of temper, and, beyond any other animal, feeming attachment to man," render, perhaps, the Dongola, or Nubian horfe, in no way inferior to the Arabian. They have, according to Youatt, " a flender, yet finely fet on neck, a noble creft, the withers elevated, a beautiful action, and an admirable bearing." The kingdom of Dongola, or Modern Nubia, produces a 
breed different from any other of either Africa or Afia. They are ufually of a black colour, but there are fome bright bays and forrels.

"The Egyptian horfe," fays Burckhardt, "is ugly, coarfe in fhape, and looking more like a cart-horfe than a racer. Thin legs and knees, and hort and thick necks, are common defeets among them. The head is fometimes fine, but I never faw good legs in an Egyptian horfe. They are not able to bear any great fatigue; but when well fed their action is occafionally more brilliant than that of the Arabian. Their impetuofity, however, renders them peculiarly defirable for heavy cavalry, and it is upon this quality alone that their celebrity has ever been founded."

Of courfe this defcription applies to the horfe of Lower Egypt, while that of Bruce refers to the Dongola, or Nubian horfe, which may be confidered as reprefented by the fculpture at the entrance of the fmall temple of Beit-Oualley (Plate I). The horfes reprefented in the frefco-painting from the tomb of a Scribe (Plate 2) are likewife Nubian horfes.

The Affyrian horfes, from a bas-relief of the north-weft palace Nimroud (Plate 3), belong evidently to another variety. The fhortnefs of their fore-legs, if not a fancy of the artift, would incline them to rear up; but we muft fuppofe the Affyrian fculptor was not here over particular about proportions in the animals which he reprefented.

This fpecimen of the Affyrian way of harneffing horfes thows, like the two preceding Egyptian ones, that thefe ancient people brought the furcingle clofe to the fore-legs of the horfe, thus inconveniently interfering with the free movements of the fore-part of the animal. The plunging of the thaft was alfo confiderably increafed by this arrangement, and it muft have rendered the aim of the warriors in the chariot very unfeady, and fcarcely therefore very dangerous to the enemy.

The horfes on the monuments of Sardanapalus III. (Plates 4, 5) are remarkable for their trappings no lefs than for the elegance of bearing of the noble creatures which they reprefent. Others, taken from an ancient bas-relief in the Palace of Forty Pillars (Chekel Minar), Perfepolis (Plate 6), are of a much heavier Thape, but well proportioned. "The two remaining perfons of the group," fays Sir Robert Ker Porter in his Travels, "are in charge of a chariot, which is drawn by a pair of magnificent horfes. . The horfes are without trappings, but the details of the bit, and the manner of reining them, are executed with the niceft care. . . The pole of the car is feen paffing between the horfes, projecting from the centre of the carriage, which is in a cylindrical fhape, elevated rather above the line of the animals' heads." In the bas-reliefs of Nakrhi-Rouftan (Plate 7), "the part of the bridle of the left horfe which covers the animal's head," fays the fame traveller, " is thickly ftudded with round, plain knobs, and large circular plates adorn the Atraps round the cheft and buttock. A muzzle paffes from between the noftrils to the 
place where we attach a curb chain. . . Two large, acorn-topped taffels, fufpended by chains, hang from the back of the horfe. The tail is carefully arranged in a regular pointing form, and tied at the top with ribands."

In Plates 8 and 9 we come more to the Weft, and to the $17^{\text {th }}$ century B.c., according to the hiftorical march of civilization. On the frieze of a tomb in the Necropolis of Lycia, one of the north-weft provinces of Afia Minor, inhabited by Greeks and an aboriginal race, called Solyni, or Thermifx, we find the fpecimen, or rather a precurfor, of Greek art, in the form of a very tall and beautiful, but rather malive horfe, led by a groom, which is thown in Plate 8 . In the following Plate two men are fitting in a chariot, drawn by two horfes. The reins, which were formerly in the hands of the younger man, are wanting, for they were molt probably in gold, or gilded bronze, which attracted the cupidity of barbarian devaftators.

The fplendid horfes of Phidias, from the frieze of the Parthenon (Plate Io), fhow to what fupreme excellence art had been brought five centuries before our era under the unclouded $\mathrm{ky}$ of Greece. The horfes of Phidias are of the pure Arabian race, although, compared with the prefent type, their head is more fquare and larger. When the horfeman is on foot his breaft is at a level with the head of the horfe; when on horfeback, his feet are lower than its knee. Here the neck of the Greek horfe is Atrong and mufcular; his fhoulders are well fet; the breaft deep; the joints ftrong, dry, and admirably perpendicular; the back is fhort, and the tail carried with a peculiar elegance. The mane is generally cut brum-wife, while the tail is long, and floats freely in the breeze. The horfeman wants neither faddle nor ftirrups; and under his directions the horfe is either racing or cantering in a gentle gallop. But no matter what motion the artist may have chofen to depict, his marble horfes are almoft really living. Their admirable proportions and fine bearing, no doubt, caufed them to find favour in the eyes, and mercy at the hands, of the Muffulman devaftators, whofe fanaticifm fo fadly mutilated the heads of the horfemen, more particularly perhaps becaufe the reprefentation of men is prohibited by the Alcoran. The bas-relief of Caftor and Pollux (Plate I I) reprefents animals and horfemen in no way inferior to thofe of the Parthenon. The two Greek muzzles for armed horfes (Plate 12) will particularly interelt the antiquarian.

From Greek we pars now to Etrufcan art, much inferior of courfe, and bearing an almoft perfect analogy with Egyptian. The team of four horfes (Plate 13) to a very fmall chariot, intended for one man, is more a fancy of the artift than a true reprefentation of contemporary life. The crown worn by the driver indicates, probably, that fuch a four-in-hand was referved only to kings or chieftains of the Etrufcans. The build of the horfes is remarkable for its length and refemblance to a modern Mecklenburgh coachhorfe. In Plate I 4 we find a fine fpecimen of horfe-racing, as practifed four hundred 
years before our era. The jockey, entirely naked, without faddle or ftirrup, is urging his horfe with a three rigid-thonged whip. He feems to have left the bridle floating on the neck of the horfe, which he is patting with his left hand, as a compenfation for the feverer entreaties conveyed by the whip. In Plate I 5 we have a curious example of the way in which Etrufcans harneffed their horfes to a car. The nuovements of the animals are as little as poffible impeded by trappings, the collar, confifting of a leather thong, tapering on the thoulder-blades, and broader on the breaft, is the only means by which the horfe is connected with the pole. The bit has a very peculiar form, acting very likely on the interior corners of the moutl, by the preffure of the four-pointed corners of a metallic plate, painted black. On the Greek painted vafe of the third century B.c. (Plate I6), with a man fanding, and a horfe ridden by a child, all painted white on a black ground, reappears the fhort form of the Arabian horfe. The young horfeman is entirely naked, and has in his right hand a double-thonged whip. The ftature of the man ftanding thows the thort proportion of the Greek horfe compared with the Etrufcan one.

We come now to the firft fpecimen known of Sarmatian or Coffack horfes, reprefented on Trajan's Column (Plate 17). The extraordinary appearance of the mail-clad horfes and riders is explained by Paufanias in his "Defcriptio Græcix," where, fpeaking of a temple dedicated to Efculapius, he fays, "We fee there, among other things, a Sarmatian cuirafs, or coat of arms. Thofe who fee it fay at once that barbarians are no lefs clever in the arts than the Greeks themfelves. Sarmatians have no iron, as no mines of this mineral are to be found in their country; and, as they have no trade with neighbouring nations, they can have none brought from abroad. Inftead of iron, they have plates of bone at the end of their pikes. With cornet-tree wood they manufacture bows and arrows, whofe points are made with bones, and throw chains upon their enemies, to frike them down. The way in which they make their cuiraffes is this: Each of thefe barbarians has a great quantity of horfes, for their land is not feparated into parts, fo as to be fubfervient to the ufe of private perfons, nor does it bear anything, except ruftic wood, as the inhabitants are nothing more than nomades. Thefe horfes they not only ufe for the purpofes of war, but they facrifice them to their country gods, and even ufe them for food. But, collecting the hoofs of thefe animals, and purifying and dividing them, they polin them fo as to refemble the fcales of a dragon. He, indeed, who has not feen a dragon may compare this compofition from hoofs to a pine-nut while yet green. This fcale-like compofition they perforate, and few it together with the nerves of horfes and oxen, and afterwards ufe them for coats of mail, which are not inferior to thofe of the Greeks, either for elegance or Atrength, as they will futtain a blow given either remotely or near at hand." *

- "The Defcription of Greece by Paufanias" (tranflated by T. Taylor). London, 1824. 8vo. Vol. i. pp. 54, 55. 
Thus the extraordinary horfes and horfemen reprefented on Trajan's Column with what feems to be a coat of mail, are covered with fcales made from horfe's hoofs. The mane and the truffed tail of the horfe are even covered with this fingular protection againt the arrows of the enemy. It is not eafy to underftand how fuch could keep on the legs of the horfe while galloping as they are reprefented; but very likely the artift did not fee by himfelf the barbarian horfemen, and not a little exaggerated the dimenfions and the form of the horn cuiraffes of men and horfes.

Another barbarian horfeman (Plate 18) appears on Trajan's Column riding at full gallop on a horfe provided with a fringed cloth (the horfeman's cloak, perhaps), inftead of a faddle, and without ftirrups. The bridle is wanting, as in the Greek monuments, but becaufe the bronze which formed it has been removed. The coftume of the horfeman is very curious, and molt likely that of a Gaul fighting againft the Romans. A loofe garment, with the neeves tucked up above the elbow, covers the upper part of the body of the rider, and falls a little below the waif; a pair of narrow breeches reaches to conceal only the upper part of the calf, the lower part of which is bare; the fandals are faftened to the ankle with leather fraps. Some rudiment of faddle muft be concealed under the loofe fchabraque, unlefs the two ftraps which are round the breaft of the horfe, and pafs under the tail, are intended to faften the fchabraque itfelf. The few Gallic coins which have come down to us often reprefent horfes, but fo badly defigned that it is difficult to get from them any idea of the true conformation of the Gallic horfe. Some of them, neverthelefs, thow fine fpecimens of the majeftic Armorican horfes, of which the Roman artift has given here but a poor idea.

The Roman horfe in all his majefty is exhibited (Plate 19) in the Ptatue of Marcus Aurelius, the work of an artift of the fecond century. The model which he prefents has been more than once copied by Italian and French fculptors of modern times.

The Byzantine horfe appears on the column of Theodofius (Plate 20), built in the fifth century. The horfe and rider prefent a fine fpecimen of art before its degradation during the middle ages. But the head is fo peculiarly fmall that it feems out of proportion with the reft of the body. Such a horfe, if true to nature, mut have been very docile, and more fit to be a lady's palfrey than a warrior's charger. It is not very eafy to underftand how the bit remained in the mouth of the horfe, as there are no faftenings of the bridle round the head.

From the reprefentation of this noble creature we come fuddenly down to the awful caricatures of Norman art, as conveyed to us by the rough defigns of the Bayeux tapeftry, executed in the ninth century, fuch drawings can neither be commended as models of elegance, nor as truthful reprefentations of the horfes and horfemen of William the Conqueror. But we are unwilling to let llip the opportunity of drawing the attention of the 
antiquarian on fo curious a monument, illuftrative as it is at leaft of fome peculiarities of coftume worthy to be remembered. The fcales with which the horfemen feem to be covered are not made of horn taken from the horfes' hoofs, as ufed by the Sarmatians, but fimply intended as reprefentations of the merhes of an ordinary coat of mail. The fpurs (Plate 2I) with a fingle arrow-headed point are remarkable, and their ufe muft have been very painful to the horfe. In Plate 22 we have the fame horfes, but with fhort legs, long bodies, and of immenfe fize, if we compare them with the diminutive, bearded groom who leads them by the leafh. The Spanifh horfe and warriors (Plate 23), from a MS. of the eleventh century, are not better drawn, but, curiounly enough, their coftume is very much the fame as that of the Norman warriors of the Bayeux tapeftry. The helmet and the arrow-headed fpurs are very like, but the faddle is more Oriental, and the hanging taffels thow the particular requifites of a more meridional country. The horfe, the dapple grey of whofe $\mathrm{kin}$ is indicated by fuch quaint hieroglyphics, belongs evidently to the Arabian breed.

The vanquifhed Parthians are fhown (Plate 24), as painted on the verrière of the Abbey of St. Denis, the burial-place of the French kings, and drawn by a French artift in the twelfth century. On the left-hand fide of the drawing is a curious figure of a difmounted horfeman, making, it would feem, a gefture familiar to ftreet urchins. The mane of a Parthian horfe is cut bruihwife, as the Greek horfes of the Parthenon.

In Plate 25 we have, from a ftained glass window in the Cathedral of Chartres, executed during the twelfth century, the reprefentation of a Knight Templar in full armour, holding in his hand a ftandard bearing a crofs. The fpur of the horfeman is tapering in a fingle point; his helmet, of a fingle piece, conceals entirely the face, but a crofs cut in the fteel allows him at once to breathe and to fee his way. The compofition is fpirited, and evidently the work of a clever artift.

The hunters in Plate 25 are taken from a MS. of the "Livre du Roi Modus," preferved in the National Library in Paris. The two horfemen (No. 2) are boar-hunters, and the lady and gentleman (No. 3) are hawking. Imitations of both drawings, but by an inferior artift, are to be found in another MS., from which Mr. Elzear Blaze reproduced "Le Livre du Roy Modus, et de la Royne Racio," Paris, 1839, gr. in-8vo, as the earlieft French book on hunting. Grace de la Vingne, who wrote his "Roumant des deduiz," at Heldeford, in England, in 1359, is pofterior to the "Roy Modus." Gafton Phœbus wrote his book only in 1387; and, again, Hardoin de Fontaine Guerin his in I 394 . Therefore thefe illuftrations of hunting are among the earlieft known from the Middle Ages. The horfeman (No. I of the fame plate) with the ftandard of the Crufaders, and the loofe garment fprinkled with croffes over his coat of mail, is Thibaut VI., Earl of Blois.

A French MS. of the Apocalypfe, written in the $13^{\text {th }}$ century (Plate 26), fupplies us with a very fine drawing of a horfe and horfeman, the latter receiving a crown from 
heaven. The breaft thong of the horfe is ornamented with precious ftones; the bridle is partly formed by a metallic chain. The horfeman has a bow and arrow in his left hand, and to his faddle is faftened a richly-ornamented quiver.

The drawing from an Englifh MS. of the fame century (Plate 27) is by no means fo good as the preceding one; but it is, neverthelefs, a curious illuftration of coftume. The horfes are covered, as in a tournament. The deep faddles, with backs like an armchair, would feem very inconvenient to a modern horfeman. The knight whofe horfe bears a Saint Andrew's crofs on his cloth has fent his lance through the fhield and body of his' adverfary, whofe horfe-cloth is covered with Loraine croffes. Both are rather fparingly clad for fo ferious an encounter, and bear their shields fufpended from the neck.

The horfemen in Plate 28 are taken from the Italian frefco-paintings of the Campo Santo di Pifa. They form part of the "Triumph of Death," painted by Andrea Orgagna, and are to be feen in the more picturefque than artitic attitude of ftopping their nofes, which appear rather difagreeably affected by the fmell from three corpfes in various ftages of decompofition.

The horfeman with the hawk on his fift appears to be the portrait, by Orgagna, of the celebrated Caftruccio, Signor di Lucca, as may be afcertained from the comparifon with the coins and medals of this petty fovereign. In order to imprefs more ftrongly on the noblemen of his time the vanity of human greatnefs, Andrea thows in this compofition a party of lords who, while hunting, happen to crofs a valley, where they find the dead bodies of three kings. Above this compofition an old anchorite, who could not be introduced here, and whom tradition affirms to have been Saint Macarius, hows the corpfes to the hunters.

The reprefentation, Plate 29, fhows a powerful horfe, ridden by a no lefs powerful horfeman. They alfo are taken from an Italian frefco-painting of the 14 th century in the Campo Santo di Pifa. The neck and the breaft of the animal are rather out of proportion with the reft of the body, although fuch horfes can be found to this day in Poland. The coftume of the rider is the moft marvellous paftiscio of antique Roman drefs and mediæval accoutrement which can poffibly be imagined. The bit of the horfe is alfo quite peculiar, and feems well adapted to check, by the lever it affords, the too powerful action of the neck. This curious horfeman is one of the followers of Pilatus, and the artift reprefents him as one of the cortége of Chrift, bearing His crofs towards Golgotha.

The two drawings (Plate 30 ) are taken from illuftrations of the French romance (No. r) of Lancelot du lac, and No. 2 of the romance of Triftan, both of the I 4 th century. The coftume of the hunter (No. I), blowing his horn, is very fingular, appearing to confint only of a loofe fhirt, open on the fides, after the Grecian cuftom; but he wears under it a pair 
of tight hofe. His helmet is no lefs fingular, evidently not intended for warlike purpofes, but well adapted to guard againit the ardour of the fun during a hunting day. The faddle is almoft modern in form. The two knights fighting (No. 2) have the common Norman faddle, in which the horfeman is feated, as in an arm-chair. This faddle is brought up very high on the thoulders of the horie, and almoft impedes the free movement of the neck. A poor, wandering knight, mounted in fuch a faddle, on a horfe addicted to plunging, mult have been almoft fure to tumble over his horfe's head at the leaft whimfical freak of the animal.

In Plate $3 \mathbf{I}$ are various illuftrations of the celebrated romance of Arthur of Little Britain, a MS. written in the $\mathrm{I} 4^{\text {th }}$ century. In the tournament the Duke of Brittany is to be recognifed by the ermine of his hield and horfe-cloth. The battle in the middle drawing fhows horfemen with fhields, upon which are painted monftrous figures, according to the practice of the Chinefe of our own time. The faddles of the horfes in the four drawings of this plate are quite of the modern Englin form.

The beautiful drawing (Plate 32) borrowed from the Hore of Ann of Brittany, MS. of the $15^{\text {th }}$ century, reprefents St. Martin, a foldier of the Emperor Conftancius, fifteen years old, dividing his cloak with a poor man, whom he met naked at the gate of Amiens on a cold morning of a molt fevere winter. The French National Library in Paris is in poffeffion of the fplendid prayer-book from which this drawing is taken. Moft of the illuminations of this MS. are reprefentations of country life and agricultural labours. All the margins of the book are decorated with reprefentations of plants and infects, drawn from life and admirably illuminated. More than three hundred various plants are there delineated, and form the moft complete herbal which we poffers from the early period of the i 5 th century.

In Plate 33 we have a reprefentation of the Duke of Brittany and the Duke of Bourbon fighting in the tournament of King René of Anjou. The Duke of Bourbon is diftinguifhed by the fleur-de-lis, forming the creft of his helmet, and which are fpread all over his drefs, and the bridle and cover of his horfe. The horfe of the Duke of Brittany wears two horns on his head, in imitation of the creft of the Duke's helmet. The drefs of the latter horfeman, the bridle and cover of his horfe, are fprinkled with ermine, the diftinctive mark of the coat-of-arms of the fovereigns of Brittany.

The cart-horfe (Plate 34, No. 1) is borrowed from a French MS. of the 1 5 th century. It would not be difficult in our days to find, in feveral parts of France, the fame horfe, with the very fame harnefs. The gentlefolks meeting on horfeback (No. 3 of the fame plate) more particularly bear the medieval ftamp of their own time. The pyramidal head-drefs of the lady, minus the veil, may ftill be feen in Normandy - worn, however, by wet nurfes, and no more by ladies having a right to bear on their horfe-cloth a 


\section{Horfes.}

feur-de-lis, quartered by two leopards. The hat of the polite gentleman, who pays his refpects to the lady, refembles very much the never-brufhed beaver of a French country fchoolmafter. The horfes feem to be as polite as their mafters, and in the very act of greeting each other by the fame movement of the head and one of the fore-legs.

Around the feal of Charles the Bold are to be read the following words, which could not find their place in Plate 34, No. 2 :- "Caroli . Dei . gracia . Burgundie . Lotharingie . Brabancie . Linburgie et Lucemburgie . ducis . Flandrie . Artefie . Burgundie . Palatini . Hollandie . Zelandie . et Namurcie . Comitis . Sacri . imperi . marchionis . dni . Frifie . de Salinis , et de . Machlinie."

The two horfes copied from early Italian mafters (Plate 35) in the Print-room of the Britifh Mufeum are not very creditable to the country which, at a later period, produced in fuch aftounding number the moft eminent artifts of the world. The fore-legs of the galloping horfe are evidently too fhort; but the other horfe and difmounted horfeman thow neverthelefs a good deal of feeling for the picturefque.

The horfe and attendant reprefented (Plate 36) are taken from an illuminated roll ftill preferved in the College of Arms, and known by the name of the Tournament Roll. This tournament was exhibited at Weftminfter, February I2th, I5IO-II, in honour of Queen Catharine, and on the occafion of the birth of the king's firft fon, who died but a few months afterwards. A coloured copy of this horfe and attendant will be found, Plate 74, vol. ii. of Shaw.*

From Italy and England, if we pass to Germany, the contraft is very ftriking between the ftyle of horfes reprefented in the preceding plates, and that of the heavy chargers drawn by German artifts. In Plate 37, for inftance, Lucas Cranach has portrayed the Margraf Albert, in full armour, with a plume of feathers, like a fhrubbery on, and flowing behind, his helmet; while he holds, leaning on the pommel of his faddle, a lance of fuch tremendous fize that it is no marvel if the horfe appears fumbling rather than cantering under its weight. Englin brewer horfes can only give an adequate idea of-the clumfy fteed here granted by Cranach to his patron.

The horfe (Plate $3^{8}$ ) by the fame artift, and with the early date 1508 , is much more elegant, and fuggefts at once the idea of a very ftrong, but fwift and fpirited animal.

Three years before the latter date Albert Dürer engraved the white horfe reproduced in Plate 39. This engraving is what iconographifts call the fmall horfe looking towards the left; the knight behind is thought to be Perfeus preparing to go and releafe Andromeda. The early date of the engraving hhows that Dürer took his model from the brewers' horfes of Nuremberg, his native place, for we very much doubt that he fhould have given fuch a heavy nag to a mythological character after his return from Italy in 1507 .

* "Drefies and Decorations of the Middle Ages." London: W. Pickering, 1848. 
The horfe (Plate 40), from the fame eminent artift, is not much better drawn than that of Lucas Cranach (Plate 37), although Dürer's horfe is at leaft galloping, while that of the former artift is virtually ftumbling on his fore-legs.

The white horfe (Plate 4I), on the contrary, is an excellent fpecimen of the war-horfe, as it was required in Albert Dürer's time. It is carefully drawn and well proportioned. The ears are fo thort that they muft have been cut, as it was the cuftom then in Germany.

From Albert Dürer, the moft eminent German artift of his age, we naturally come down to his colleague, Burgkmair, who delineated fo many horfes in his engravings. The late Mr. W. A. Chatto, in the "Treatife on Wood Engraving," London, I839, 8 vo. plate 355, fays of Burgkmair:- " "His horfes are generally ftrong and heavy; and the men on their backs of a ftout and mufcular form. The action of the horfes feems natural, and the indications of the joints, and the drawing of the hoofs, which are moftly low and broad, evidently how that the artift had paid fome attention to the ftructure of the animal."

Very heavy, indeed, muft have been the horfes in Plate 42 -one led by a Hungarian magnate, the other by a Trabant. On the leather apron of the firft horfe the artift has engraved his monogram, H. B. The heads of the two horfes are protected by a fteel vifor, and they are crowned with a garland of leaves, for they form part of the feftive cortége of the Emperor Maximilian.

In Plate 43 the horfes are lighter and of a more homely character. The rider in the upper part of the plate has been thrown from his horfe; and, as one of his feet is ftill entangled in the firrup, the poor horfeman is in a very critical pofition, for he is moft likely to be dragged along by the frightened horfe. The horfe and cart below feem almoft to belong to our own time; the fpokes of the wheels alone, if not a fancy of the artift, prefent an object not to be eafily met now-a-days in Germany.

The clarionet-player (Plate 44), crowned like his horfe with a garland, is mounted on a common palfrey, as behoves a pacific warrior. The cafe of his inftument is faftened to the bow of the faddle.

The St. George (Plate 45), engraved in chiaro-obfcuro, is one of the moft beautiful engravings of Burgkmair. The horfe, befides a fteel vifor, has his neck protected by a coat-of-mail. The leather covering is fringed around, and highly ornamented with arabefques. On the left fide of the croup is painted, or embroidered, the image of a pelican. From the helmet of the horfeman, the head, and even the tail of the horfe, a cloud of feathers is waving in the breeze. In Plate 46 we fee how the leather apron of the horfe is faftened to the bow of the faddle by a ftrap and buckle. The two horfemen (Plate 47) are borrowed from the Tewrdannck, fol. 25, of the edition of 1519. Hans Schaueflein, pupil of Albert Dürer, who engraved moft of the plates in this bosk, reprefents here Tewrdannck, the perfonification of the Emperor Maximilian, and his faithful efquire, 
Ernhold, fallying forth on horfeback in fearch of adventures, rather uniform in character, but no lefs wonderful and flattering to the phyfical ftrength of the wandering knight. The three horfemen at full gallop (Plate 48 ) are the work of the fame artift. The horfe in advance has his tail cut thort - a feature rarely met in fuch early pictures. All of thefe horfes are truly typical of the German breed. In Plate 49, taken alfo from Schaueflein, we have reprefentations of ladies on horfeback - one fitting by herfelf; the other behind her hufband, whofe waif the embraces to maintain her pofition. The two ladies are not litting aftride, but in the ladylike fathion univerfal in Europe among well-bred people.

The knight (Plate 50) with a wild-boar's head on the point of his fpear, and followed by a tame lion, is the famous Guy, Earl of Warwick. That engraving is taken from the hiftory of the Englifh Don Quixote, written by Samuel Rowlands, and printed by Edward Allde in 1607,4 to. The fame engraving is to be found, on a very fcarce ballad of the time, preferved at the Britifh Mufeum, in the Roxburgh collection of fpecimens of popular fongs and broadfides. The engraver, in transferring the drawing to the block, did not take care to reverfe his transfer, and the refult is that the famous knight carries his fword on the right fide, as in former times executioners were bound to do, left they fhould be miftaken for honeft warriors.

A Rufian on horfeback, by Hans Weigel, is reproduced in Plate $5 \mathrm{I}$, from "Habitvs præcipuorum populorum," Nuremberg, 1577, in-fol. Plate clxxi. The horfeman is apparently dreffed in a padded overcoat, which affords protection both againft the cold and the arrows of an enemy. The bow is kept in a cafe hanging from the girdle by a ftrap; the arrows in a quiver on the right-hand fide.

In Plate 52, from the fame work (Plate clxv.), H. Weigel reprefented a Hungarian nobleman riding a horfe of the fame breed as the preceding one. The bow-cafe is hanging by a ftrap on the right fide of the horfeman, while the quiver is faftened between his fhoulders by another ftrap. The curb and fpurs are of an almoft modern form.

A German faddle and ftirrups of the latter half of the 16 th century (Plate 52), are copied from the "Kunftwerke und Geräthfchaften des Mittelalters und Renaifiance," by C. Becker and J. von Hefner. Francfort, I852. 4to. vol i. p. 52. The Atirups prefent a fine fpecimen of workmanthip, while the front and raifed back of the faddle are covered with exquifite bas-reliefs of antique cavalry fighting, in emboffed iron.

Lucas Van Leyden has fome beautiful fpecimens of horfes, and among them the noble fteed (Plate 54) engraved in 1516 . The fpurs of the horfeman are not only tapering in a fingle point, but their fhaft is in form of a faw, and their ufe muft have been moft cruel for the animal.

The horfes of Joft Amman (Plate 55) are lefs heavy than thofe of Burgkmair or Albert Dürer, but they evidently belong to the German breed. Their leather horfecloth 
and trappings very much refemble thofe of Burgkmair horfes.

Jan Van der Straat, or J. Stradanus, in his "Equile Joannis Auftriaci," in-fol. f. 1. et a., but printed at Antwerp by $\mathrm{Ph}$. Galle, and engraved by $\mathrm{H}$. Wiercx, has drawn fome fplendid fpecimens of horfes, from which the two Roman horfes (Plate 56) were taken. Their ears are cut fhort, after the antique fafhion; the mane is flowing in all its luxuriance; the tail of the left horfe is truffed up, but the other prefents an abundance of curling hair. The joints alone are heavy, and not well fhaped. The right-hand horfe is ftyled " equus matronalis," and, of courfe, is intended for a lady's horfe.

The equeftrian portrait of Francis I., painted by Janet in the fixteenth century, was fome years ago in the poffeffion of Mr. Henry Farrer, the eminent collector of works of art in Bond Street. We have reproduced it (Plate 57) after the capital engraving which is to be found in Shaw's "Dreffes and Decorations of the Middle Ages," vol. i. plate 83 .

The three heads of horfes (Plate 58) are drawn after Leonardo da Vinci.

From Italian art we come back (Plate 59) to another fine fpecimen of Van der Straat's horfes. The noble animal here delineated evidently was at once of great ftrength and wonderful fwiftnefs. It is engraved in the "Equile Joannis Aufriaci," plate 9, and is given as a Theffalian horfe.

The quaint horfes of Martin Zeiffinger, engraved in I5OI, could not be paffed over in a book like the prefent. They will be found in Plate 60, where three horfes are reprefented in three different attitudes, - one ftanding, the other at full gallop, and the third backing under the hand of his rider.

This collection of fixty drawings could not be intended as the illuftration to a complete hiftory of the horfe, but by the varieties of fpecimens borrowed from the beft fources we hope it will be found acceptable to the artift and antiquarian, as well as to the naturalift and fportfman. 


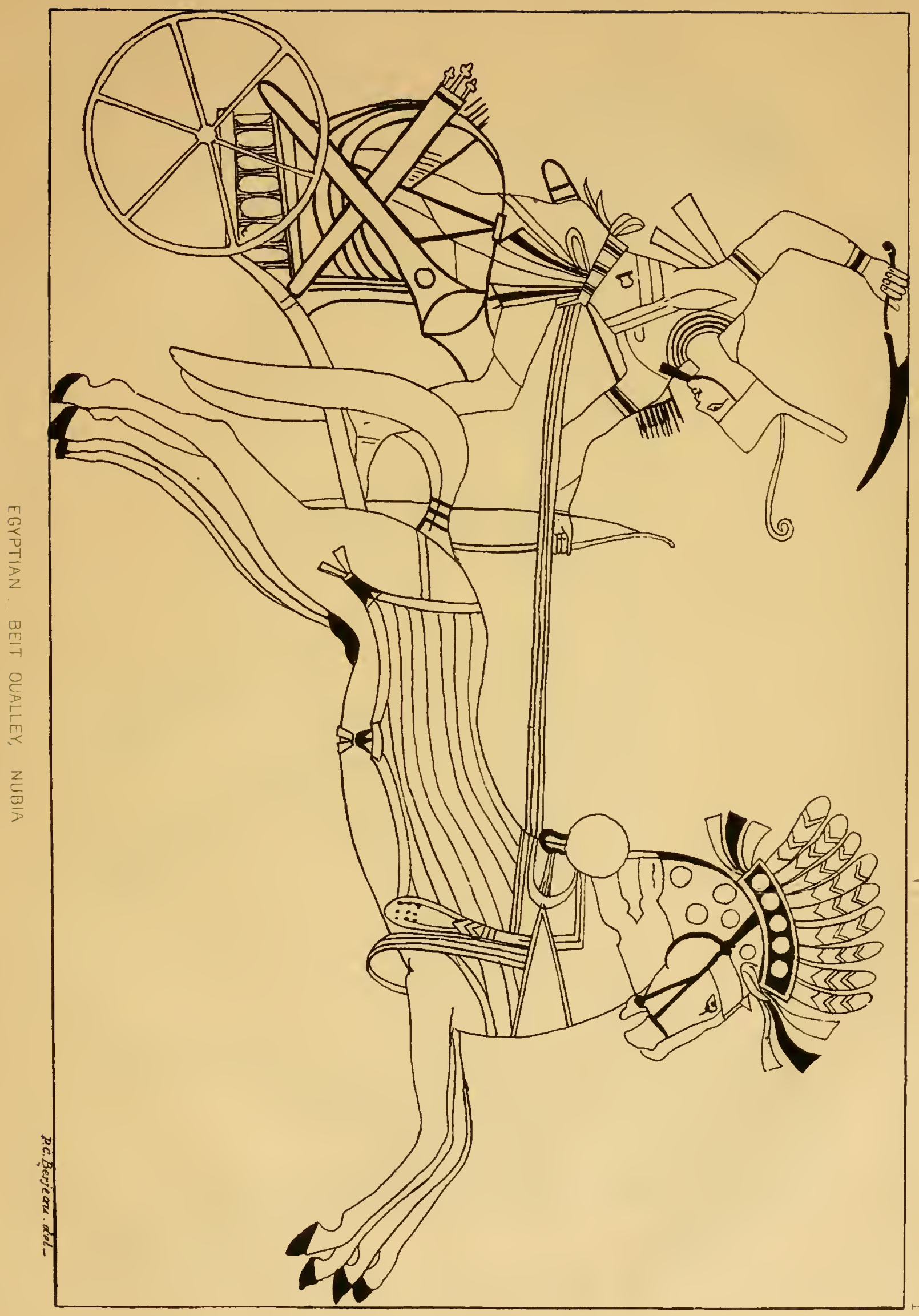





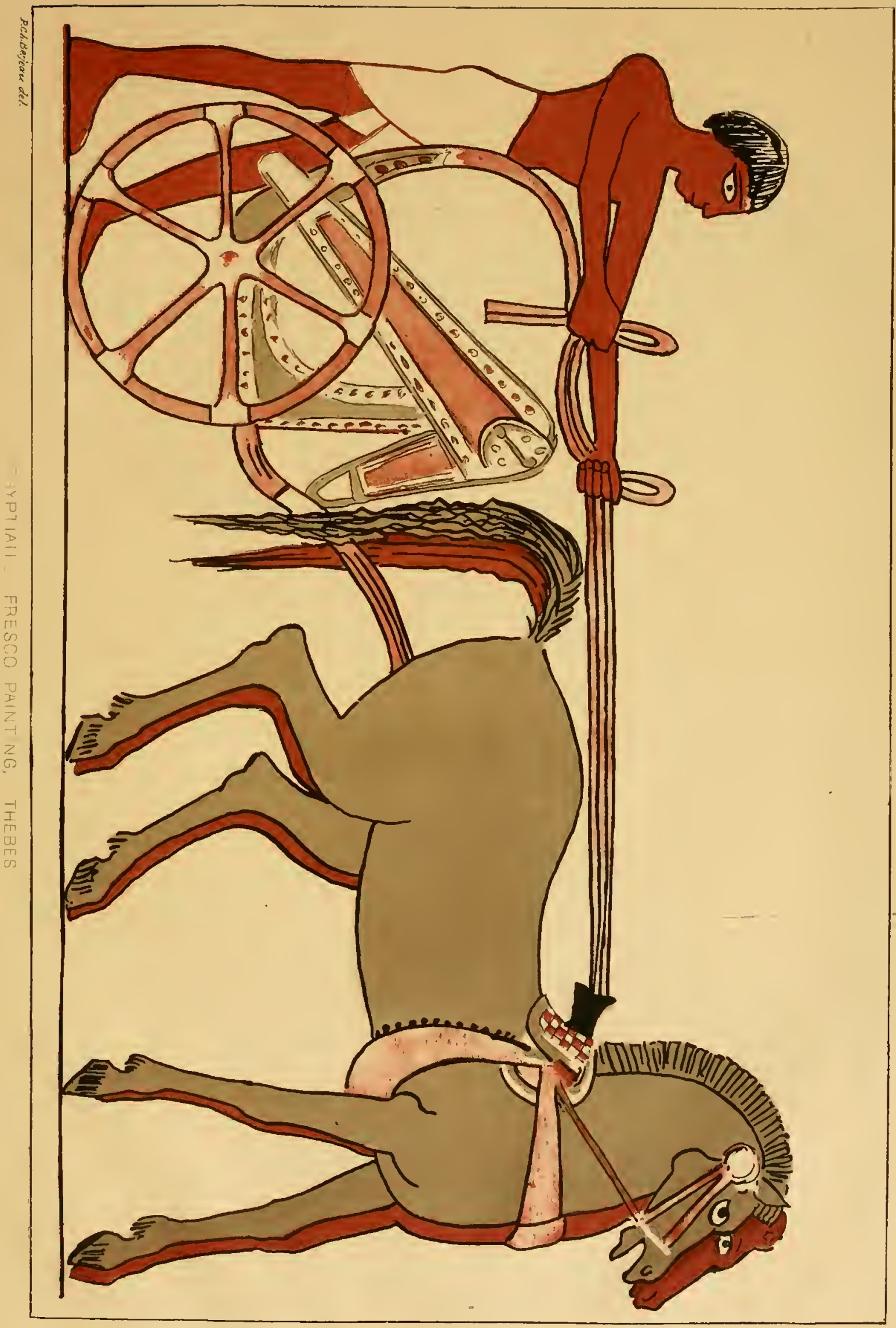





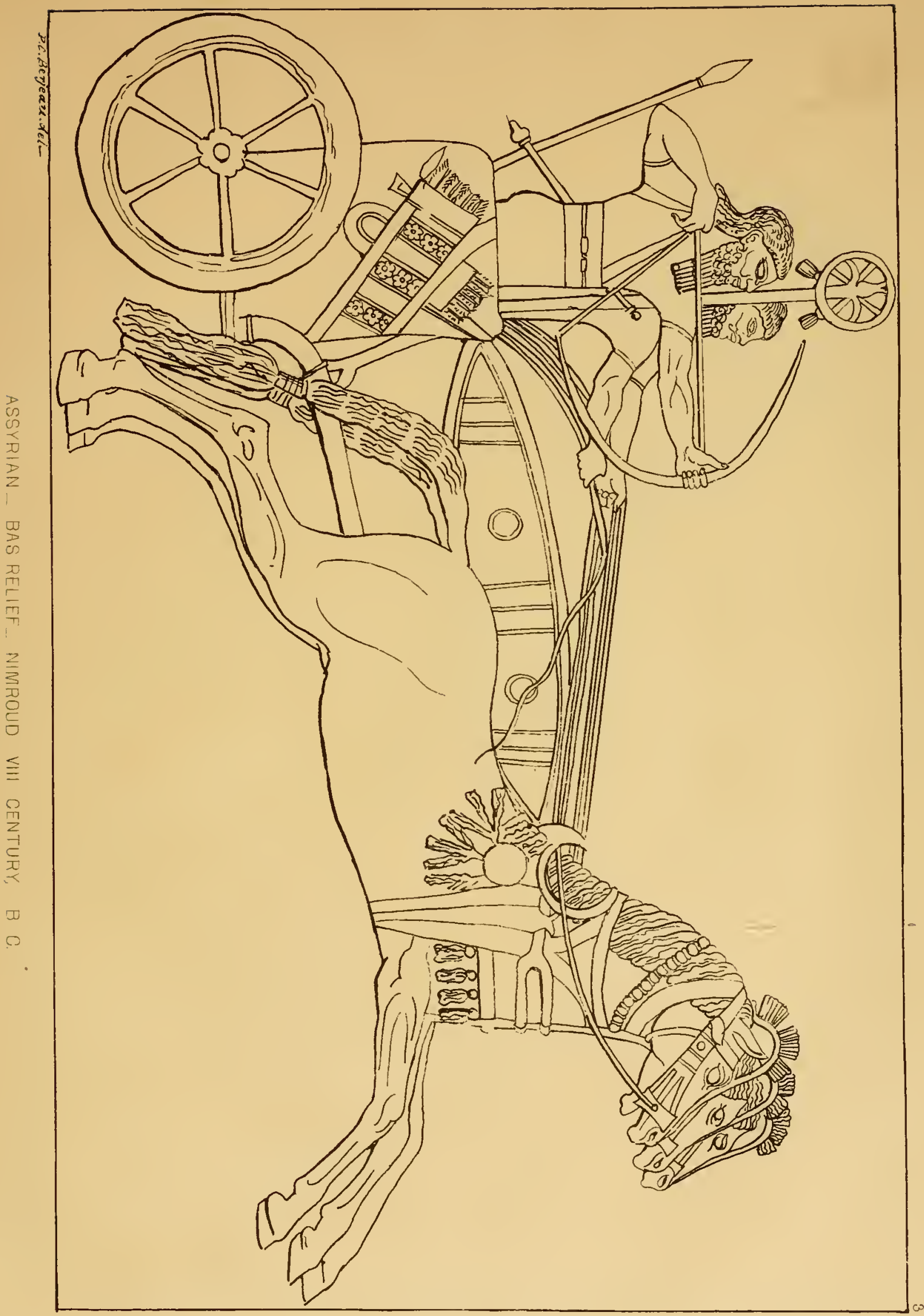





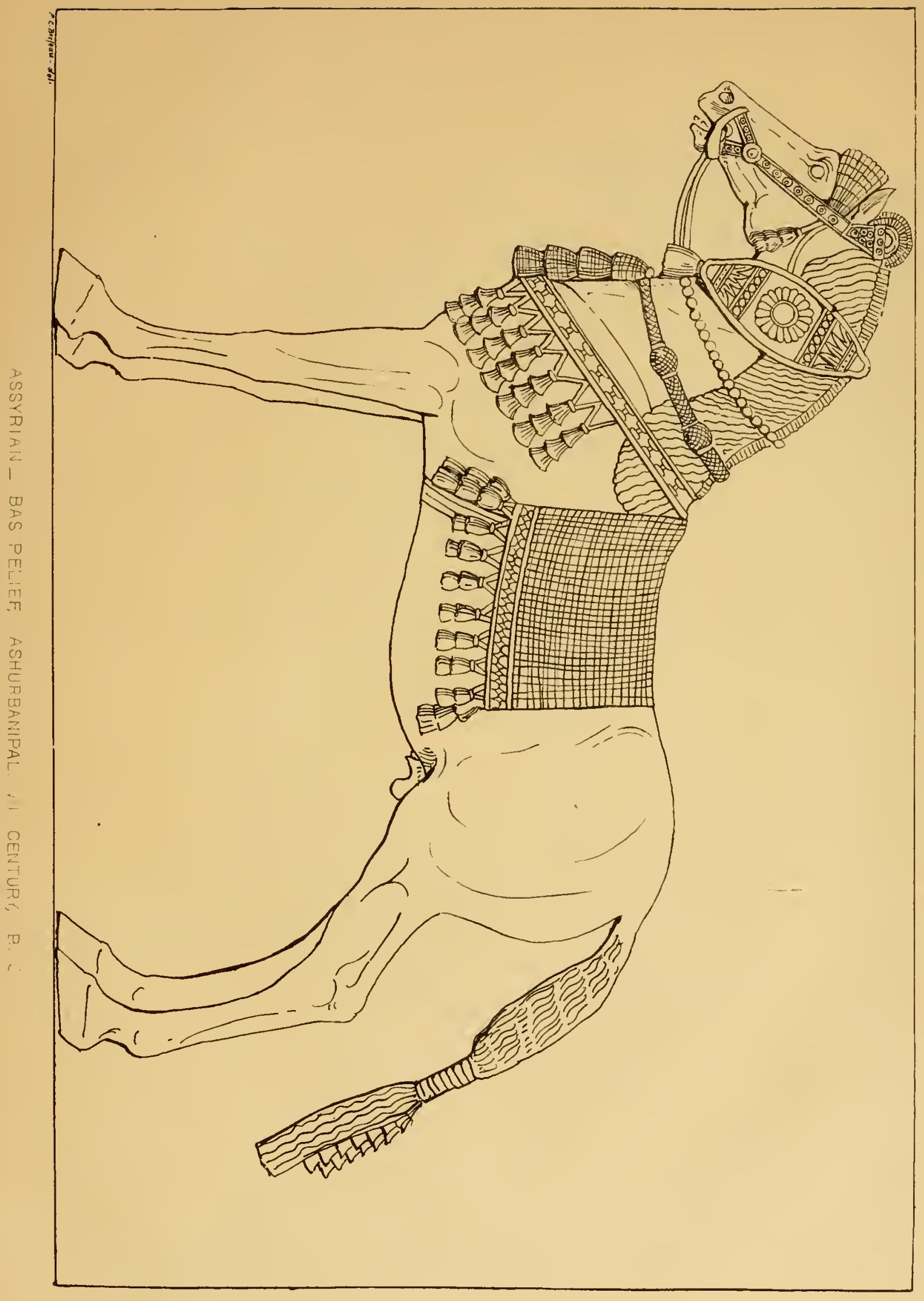





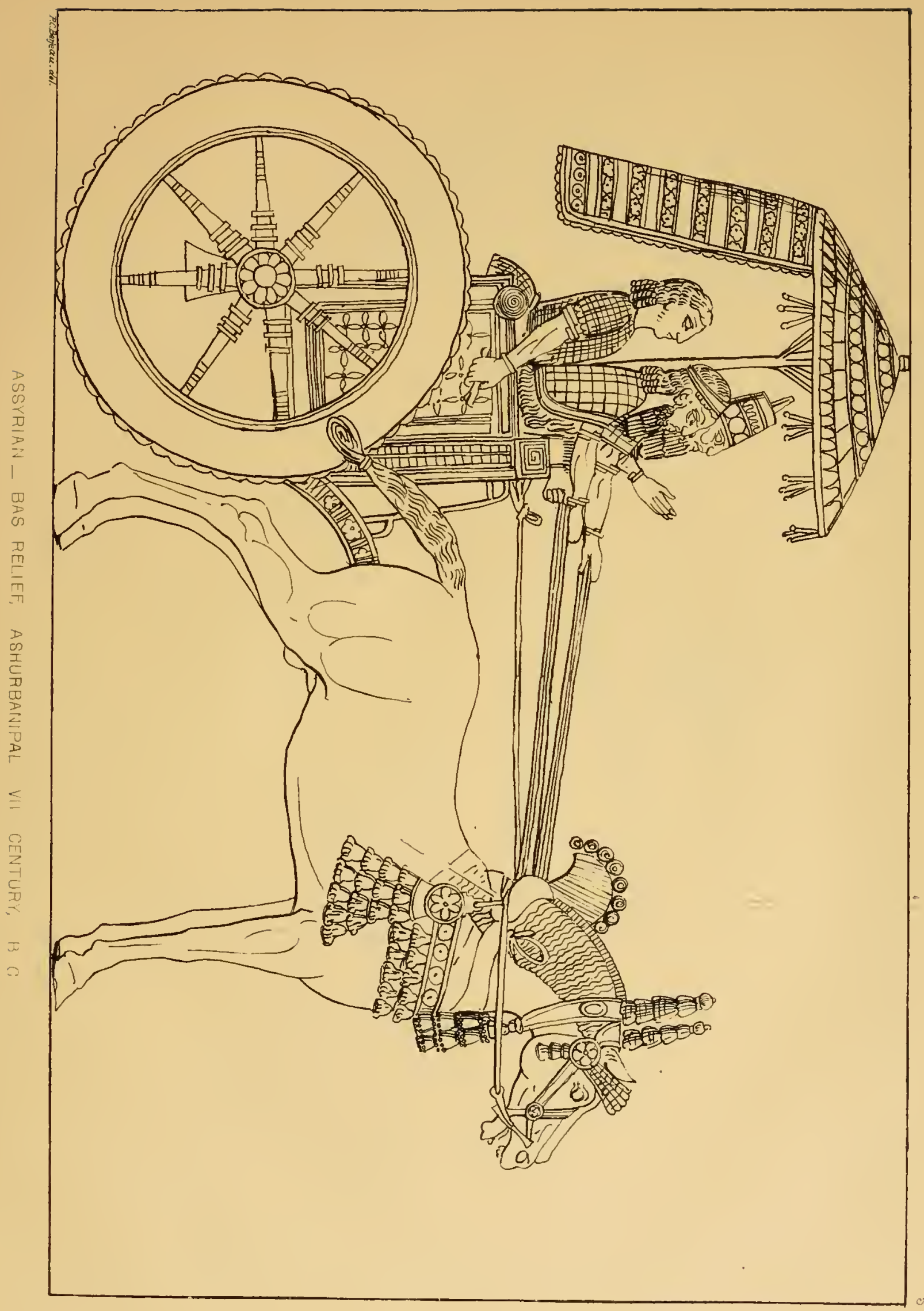





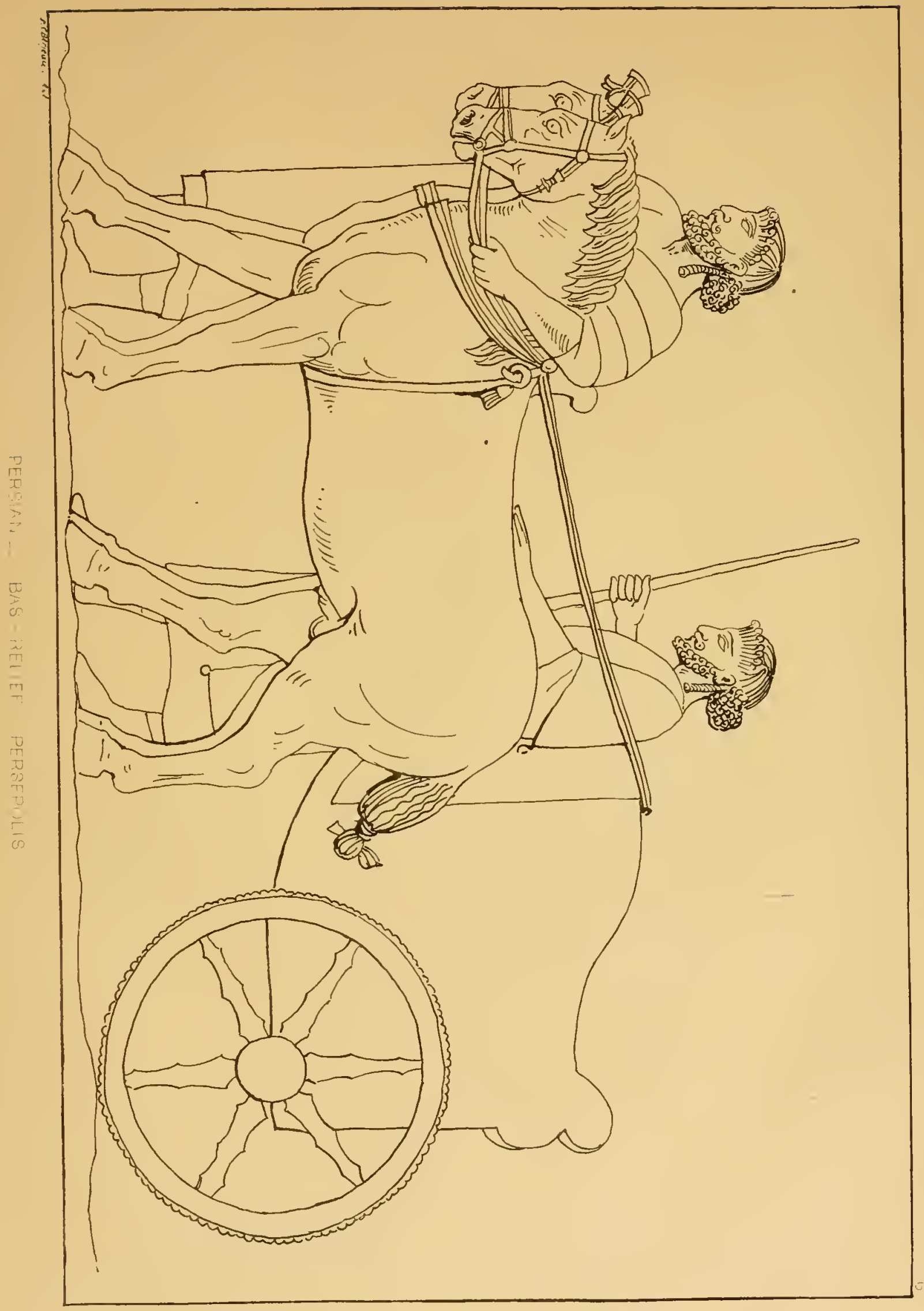





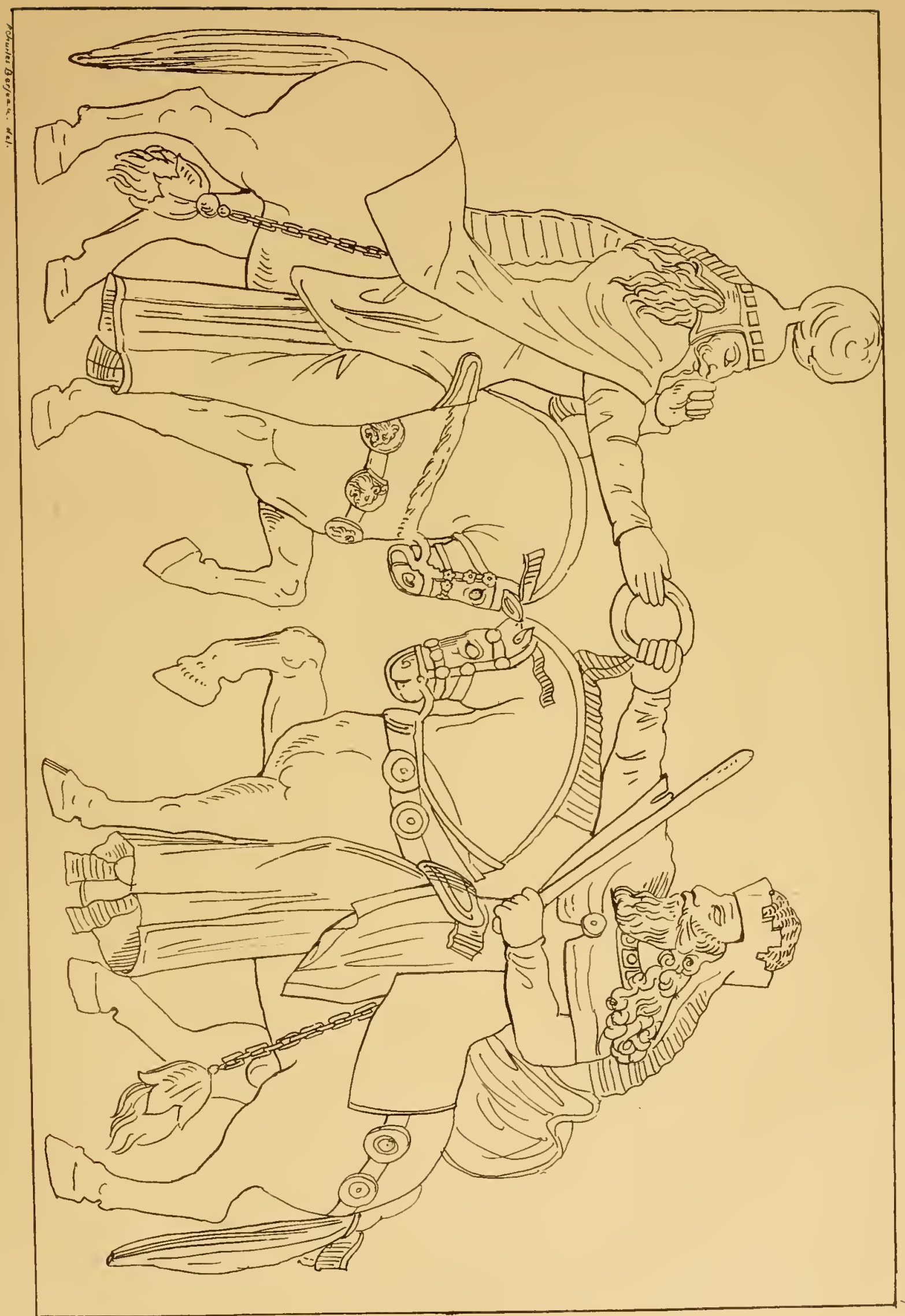





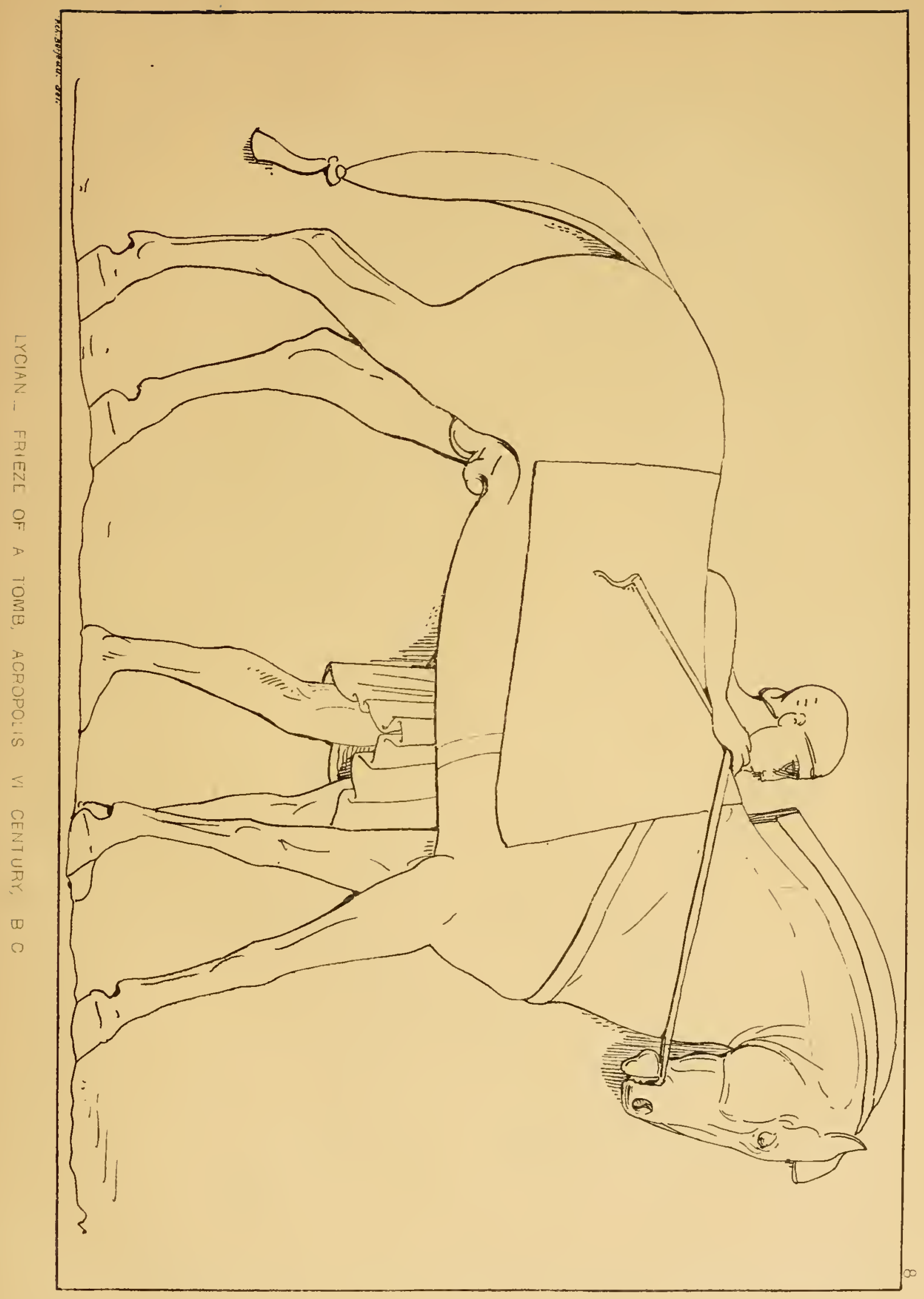





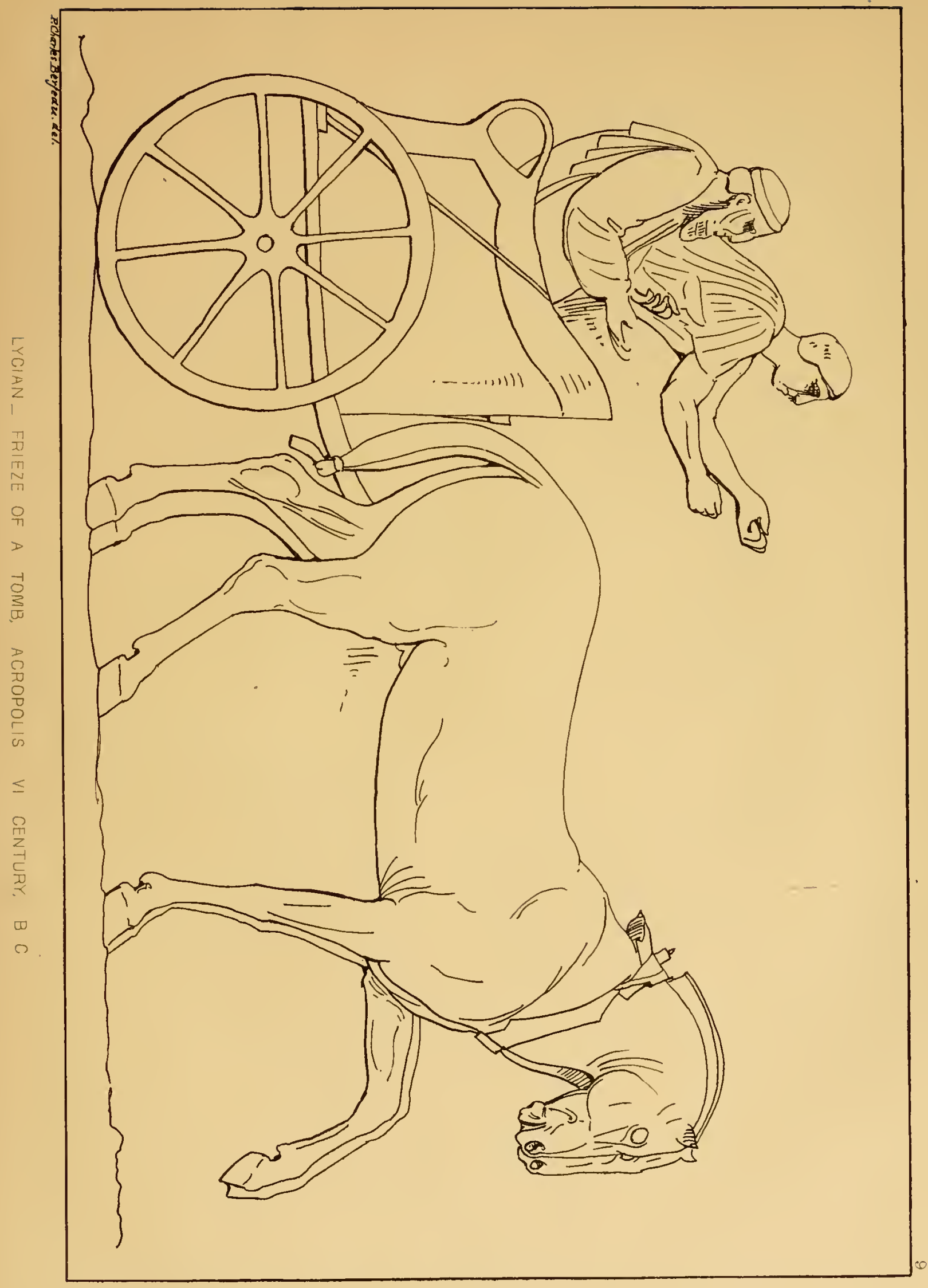





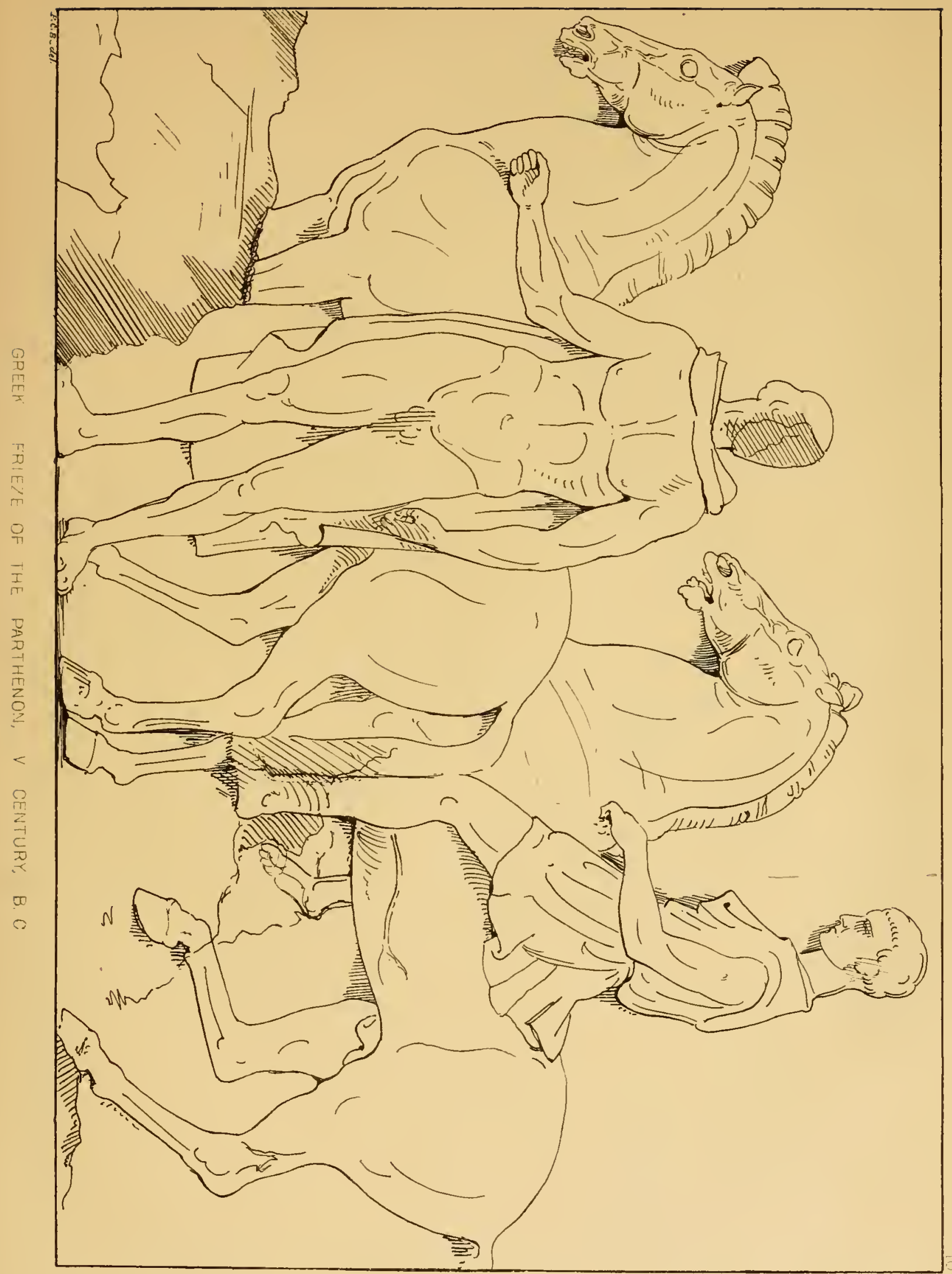





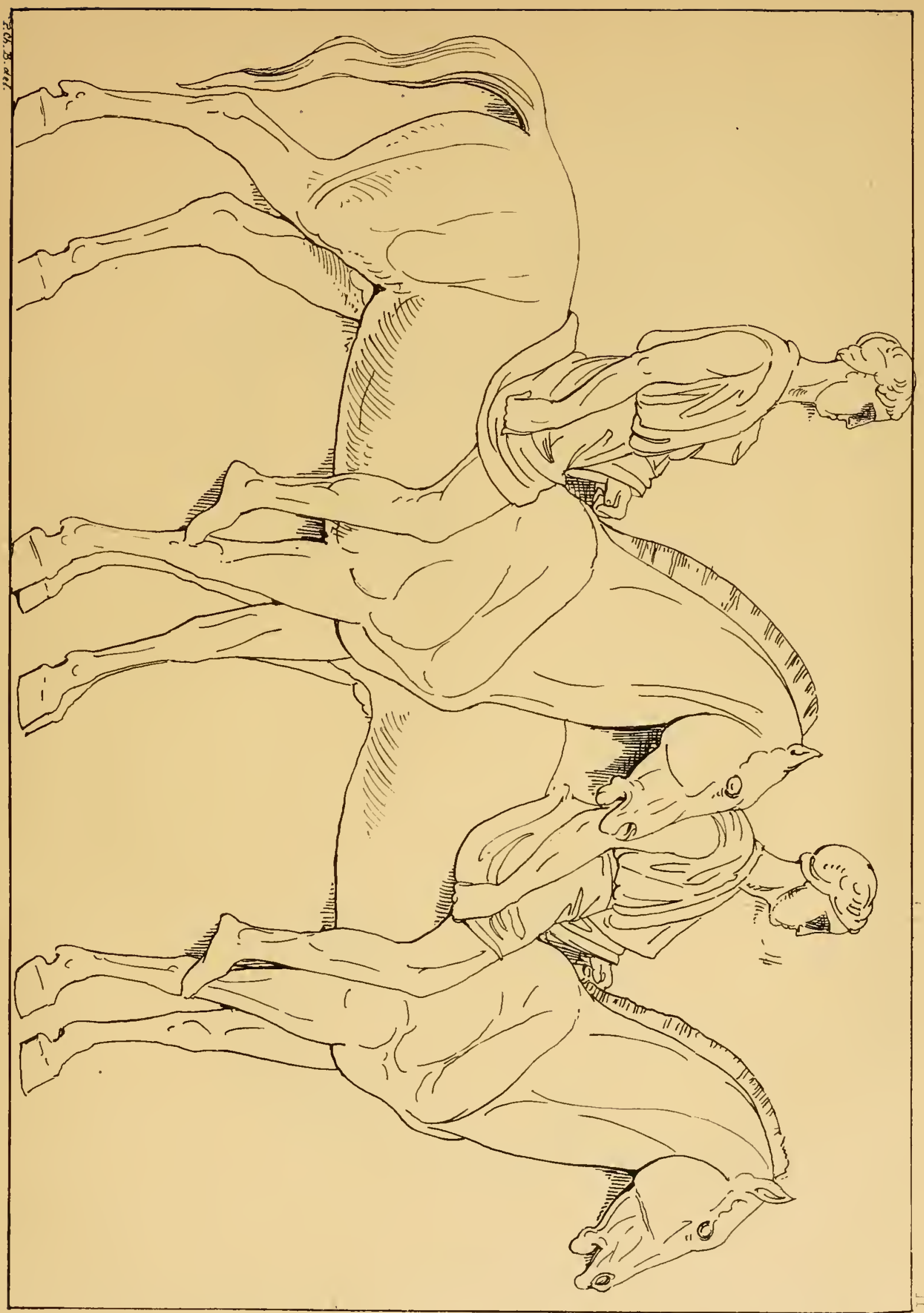





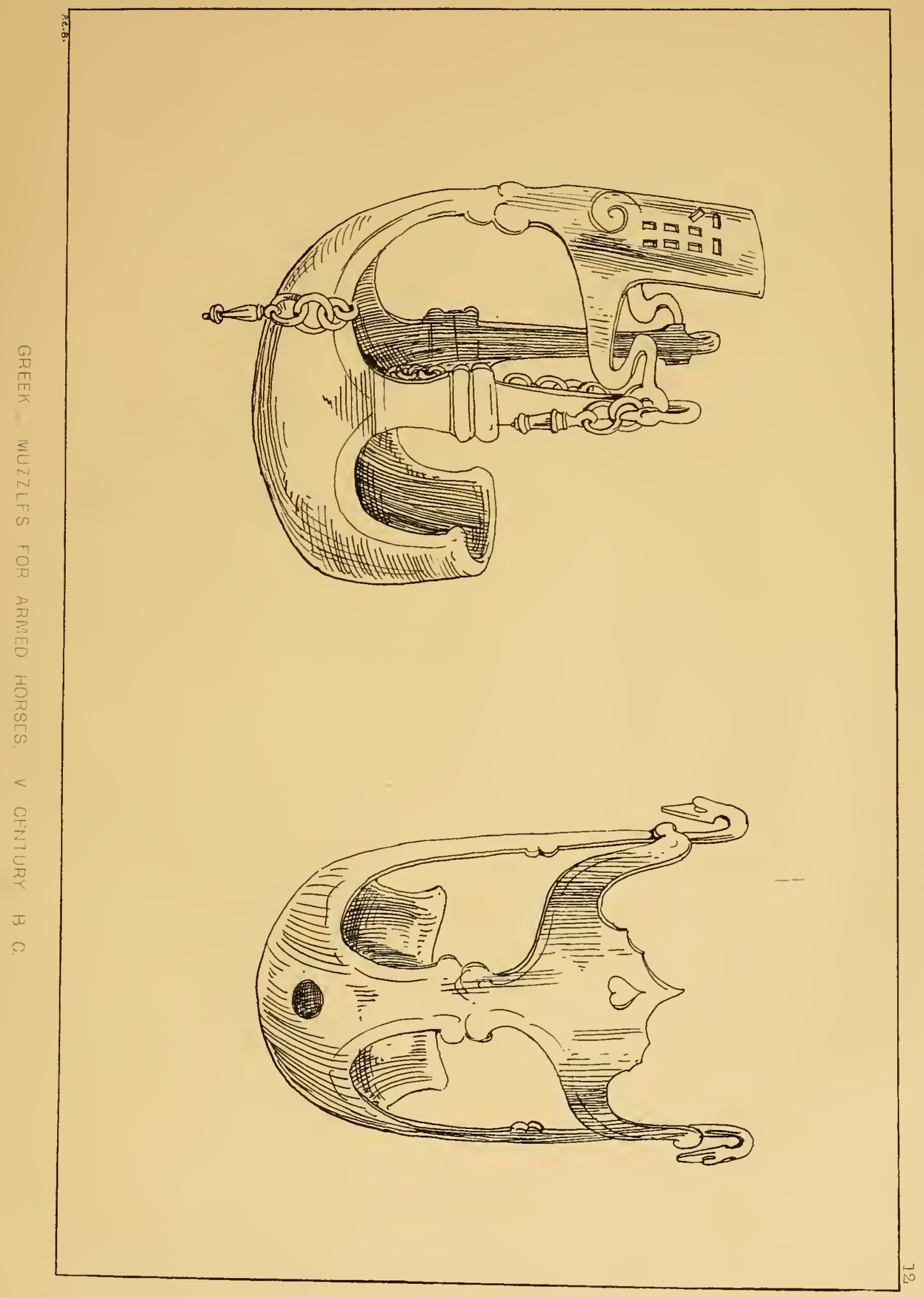





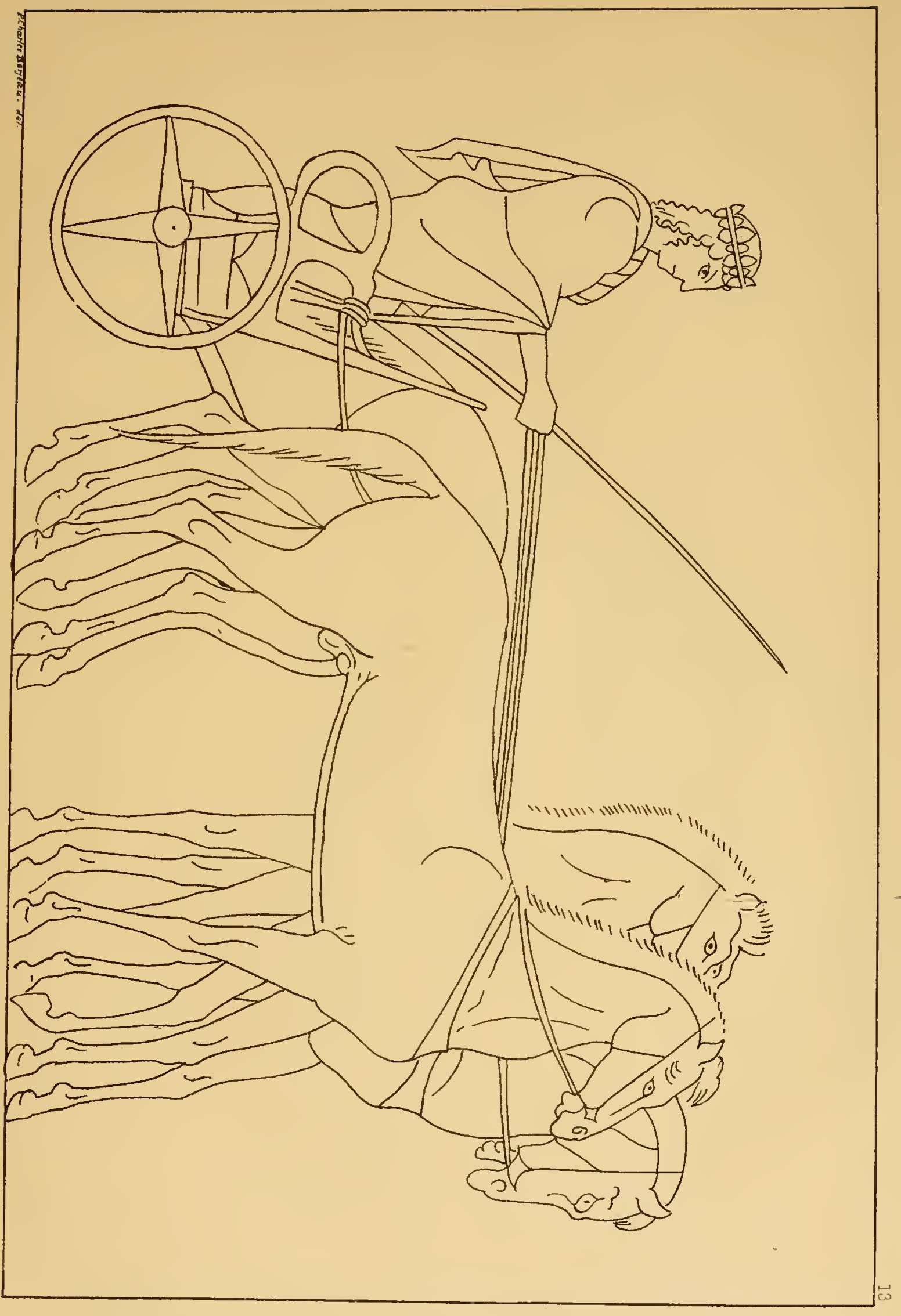





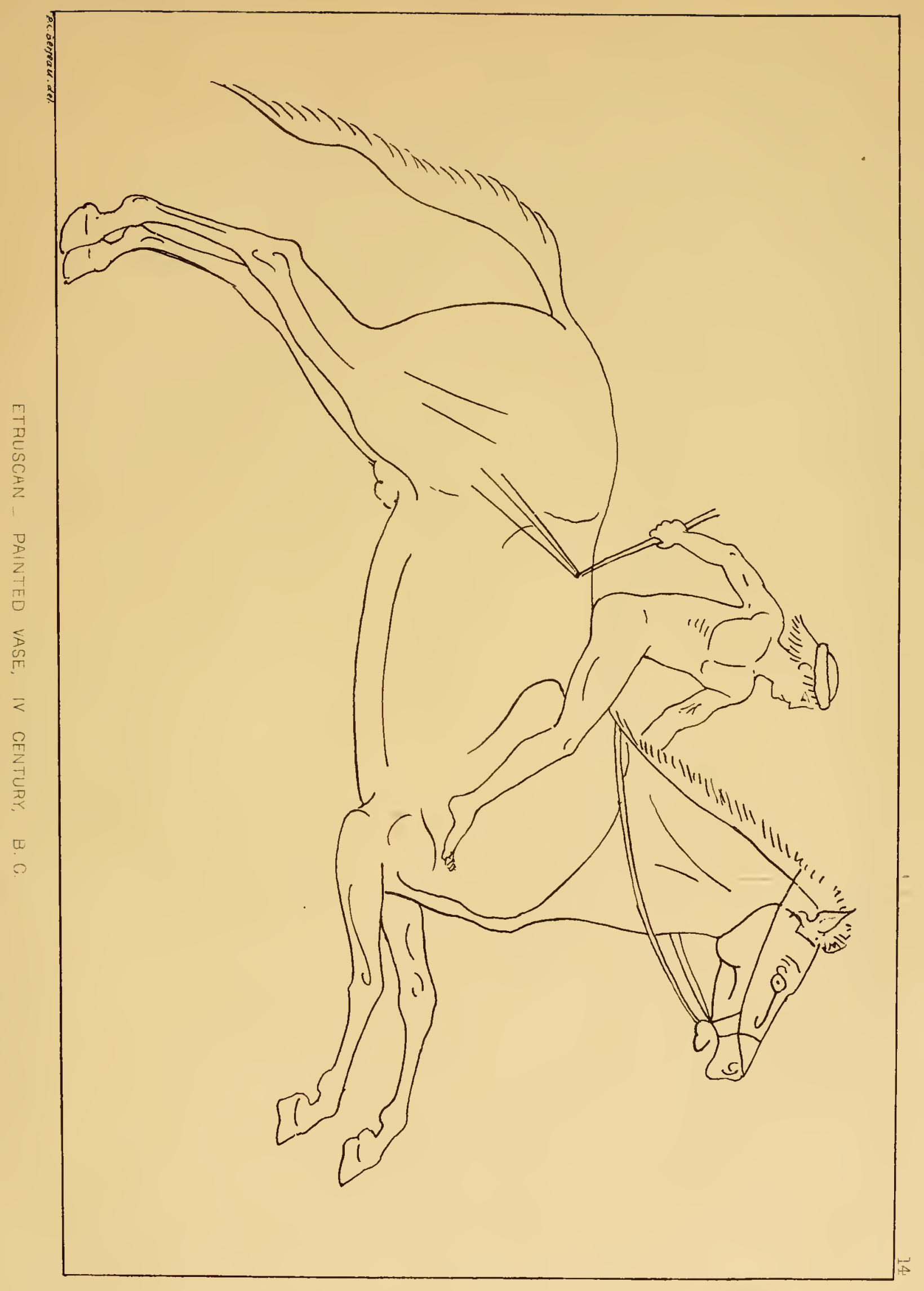





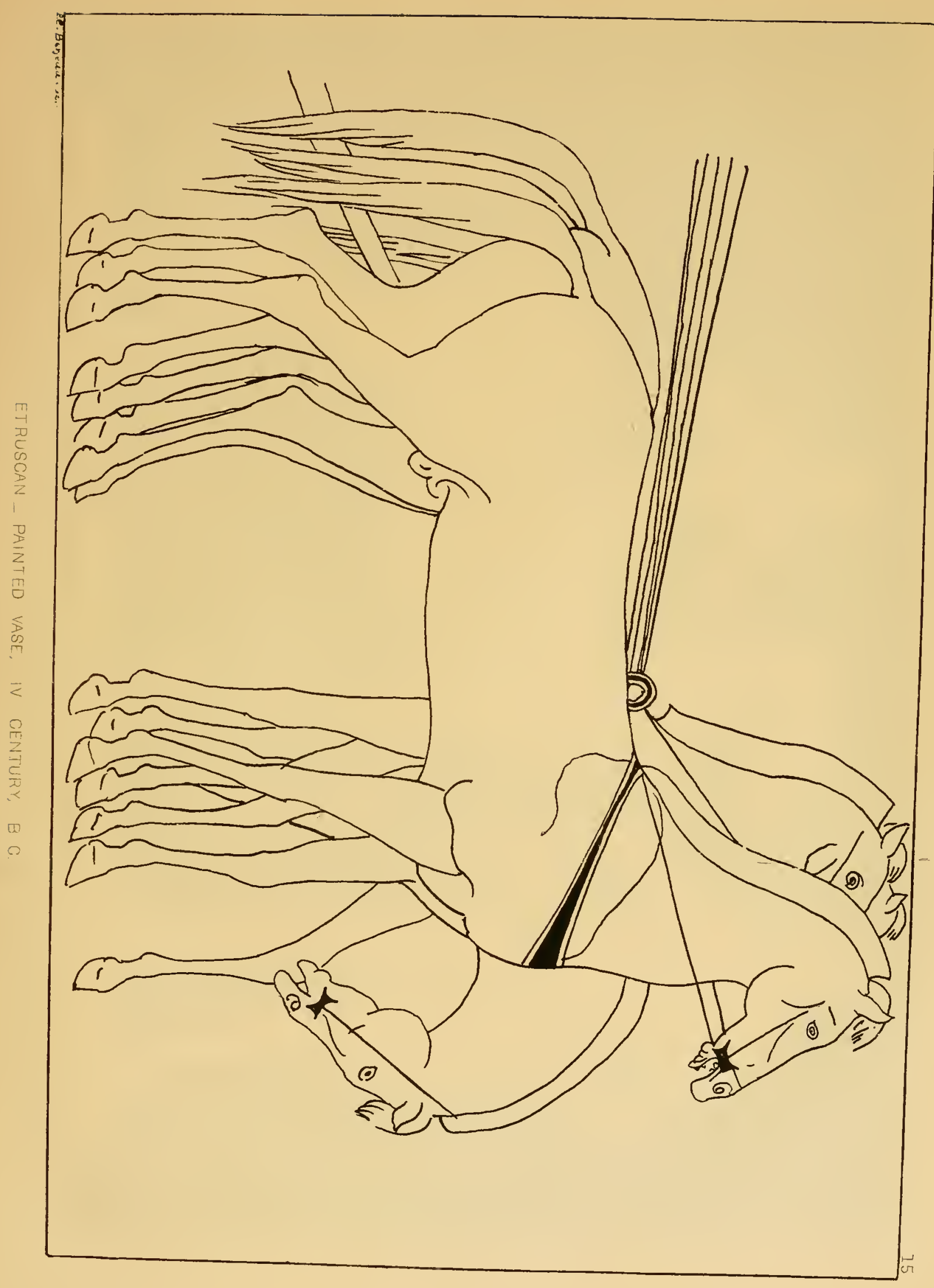





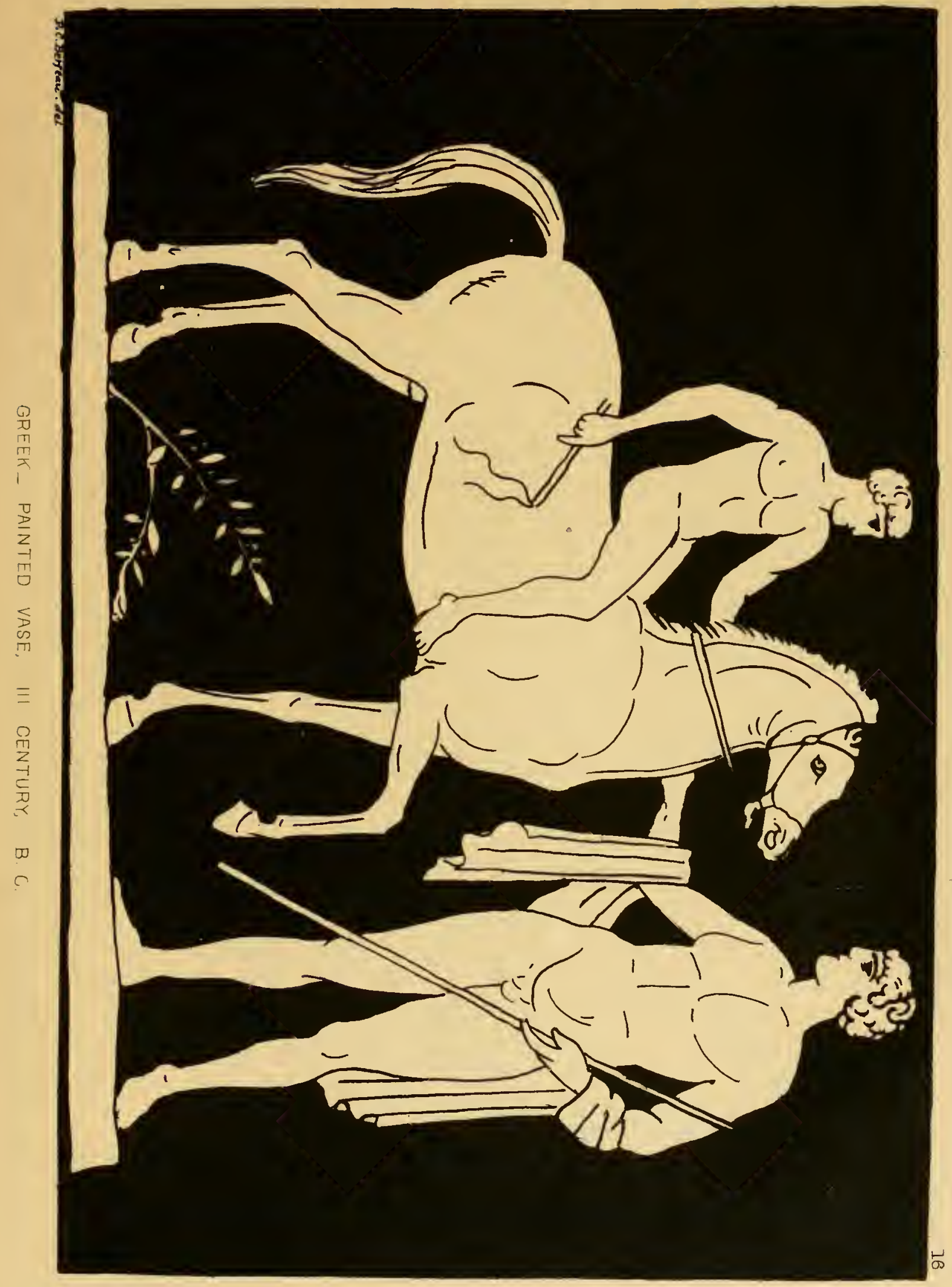





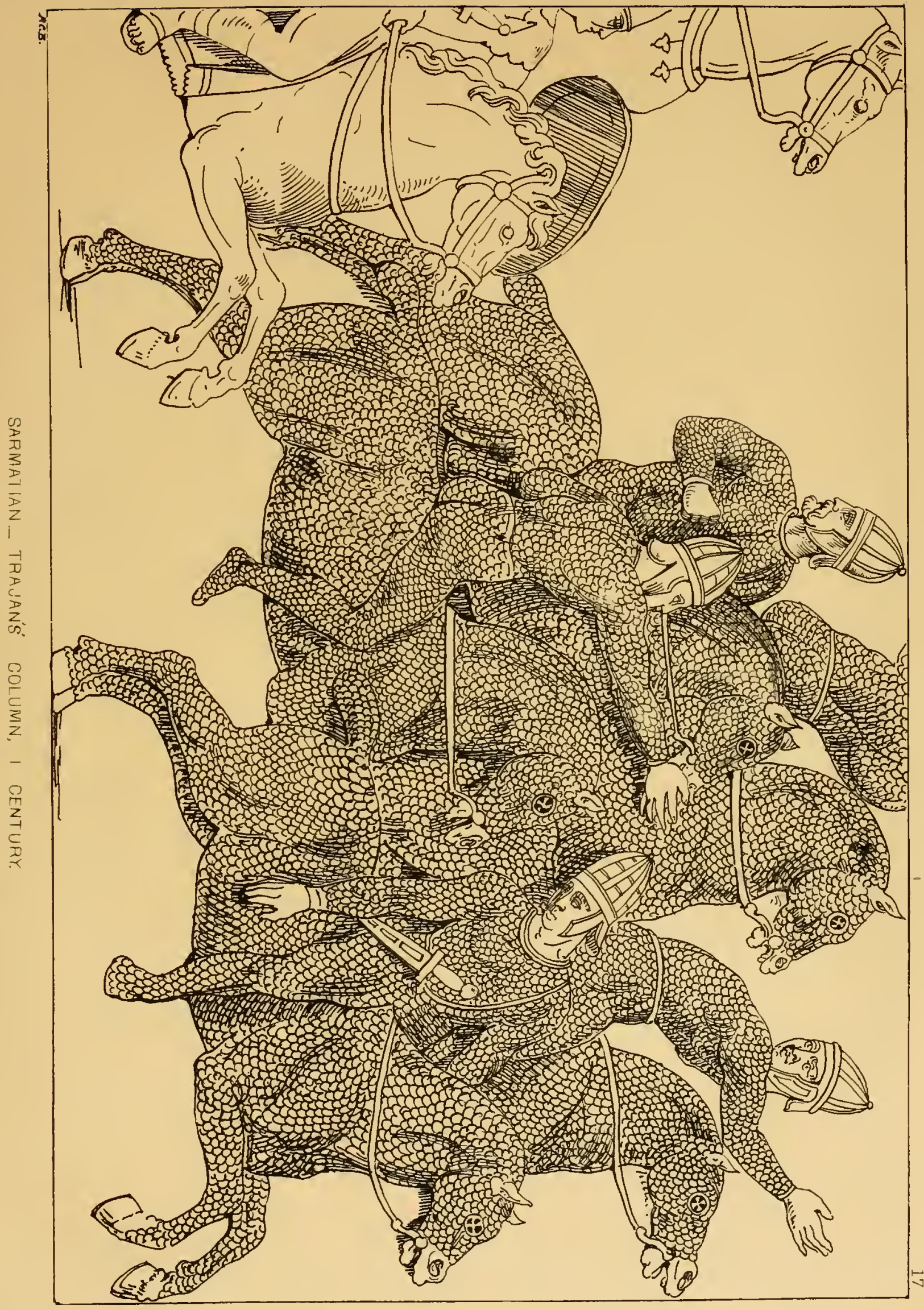





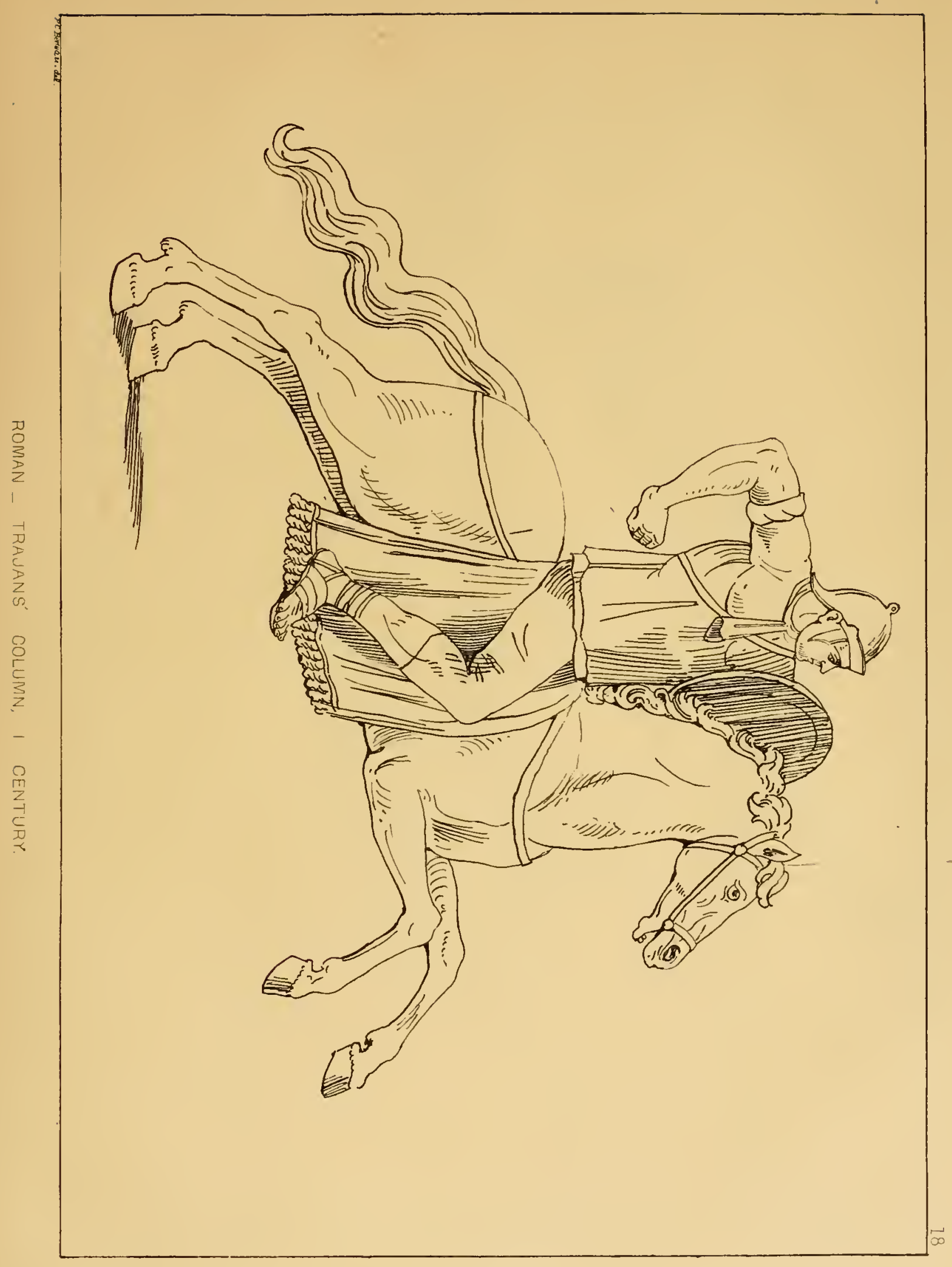





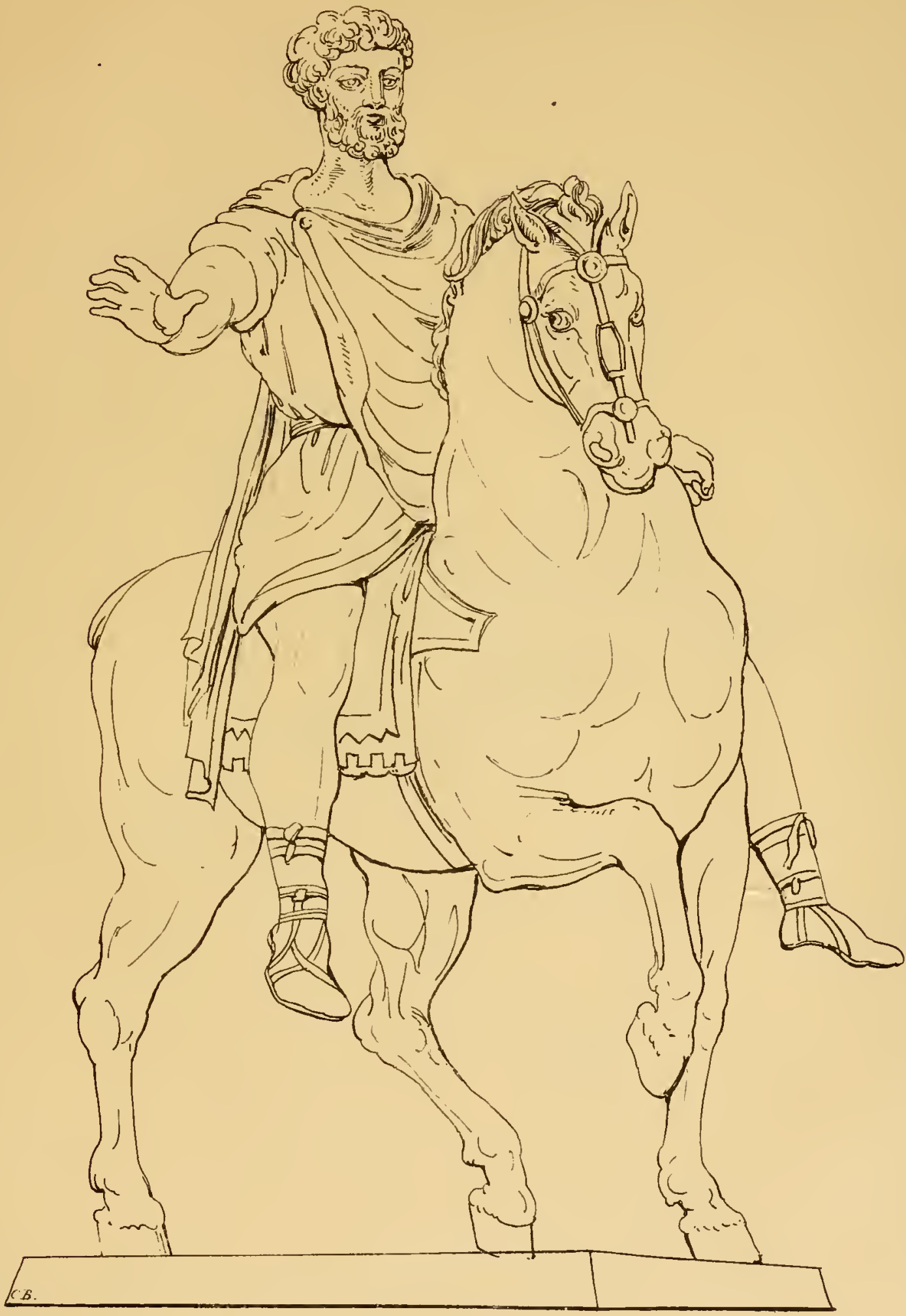





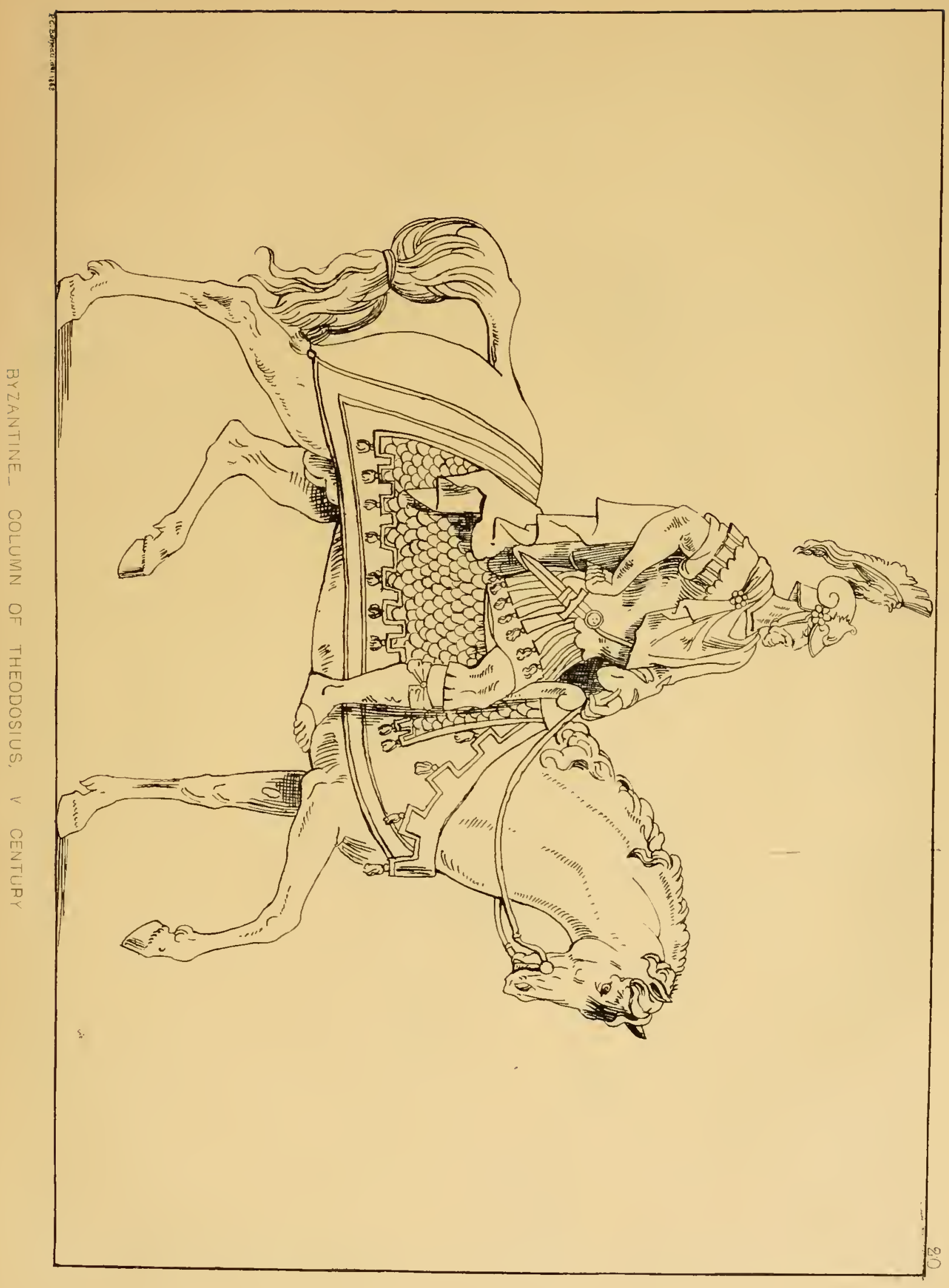





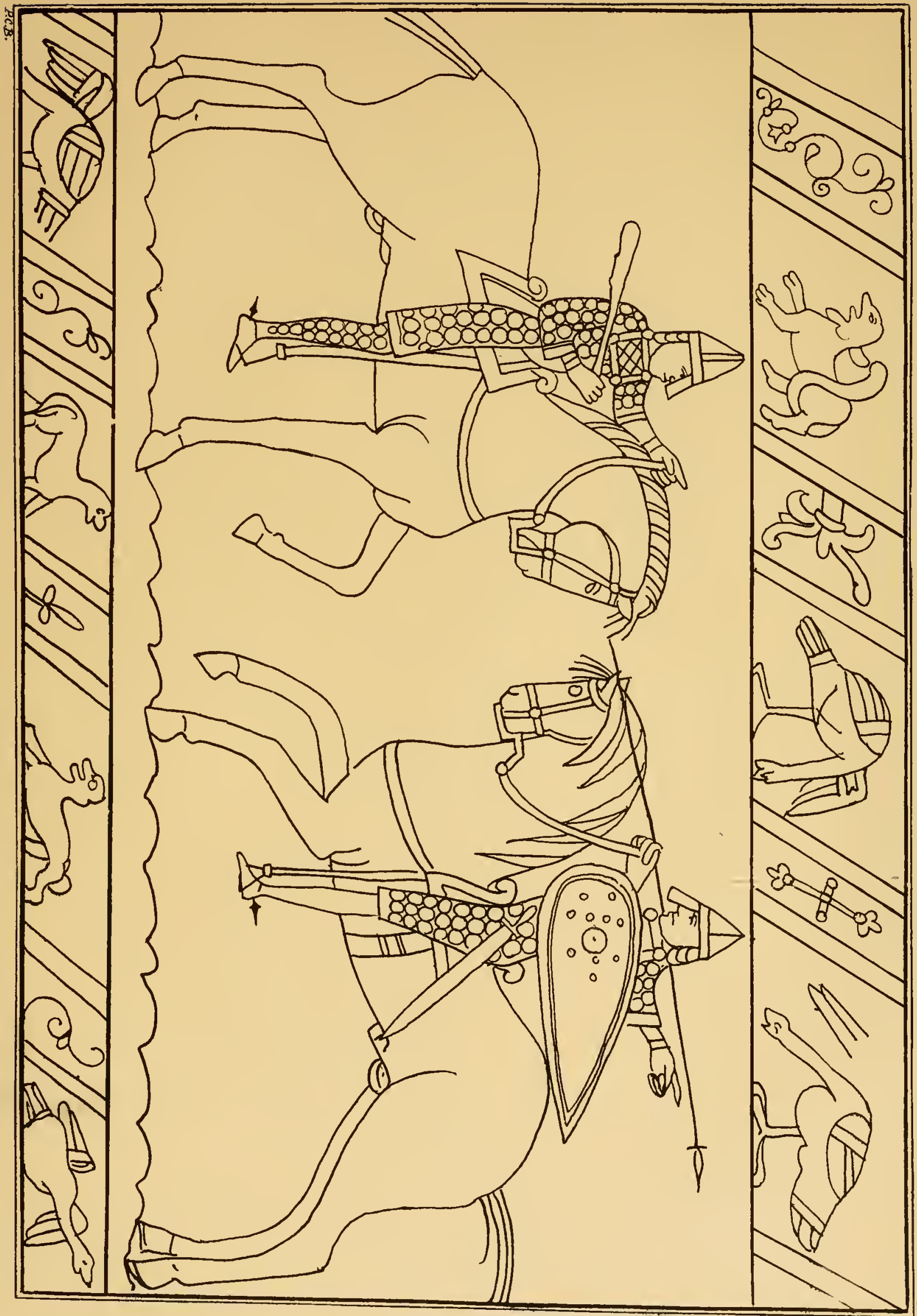





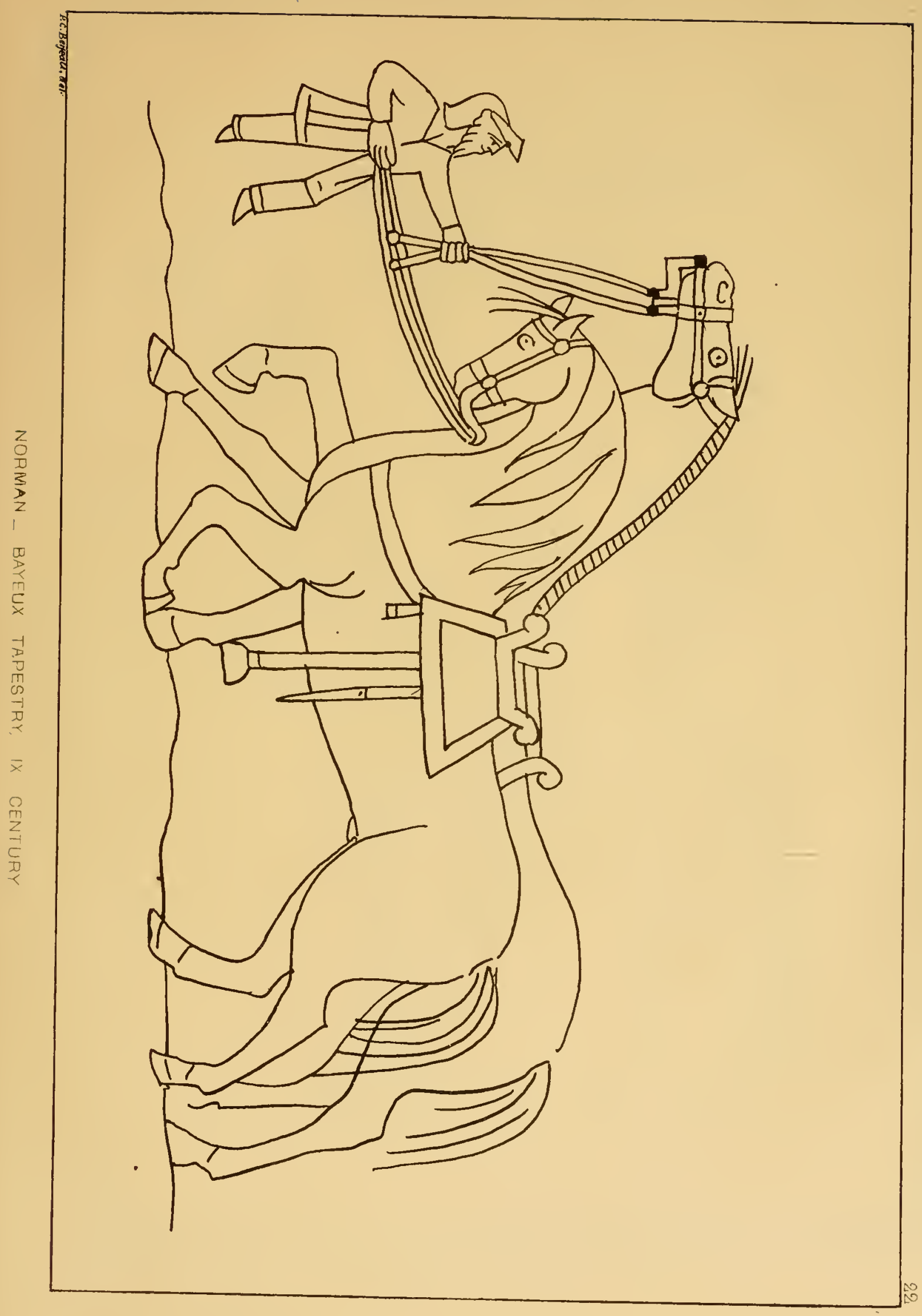





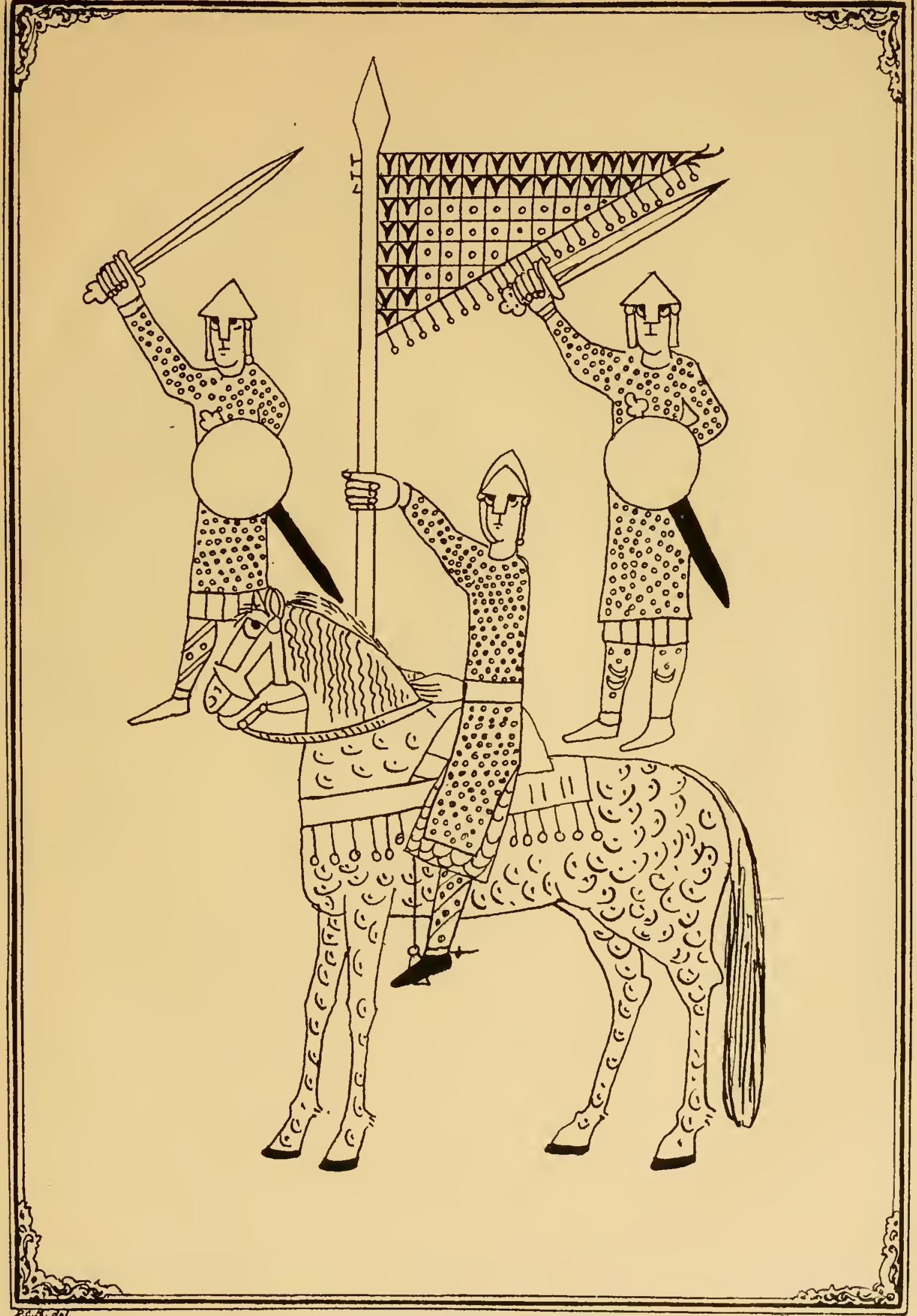





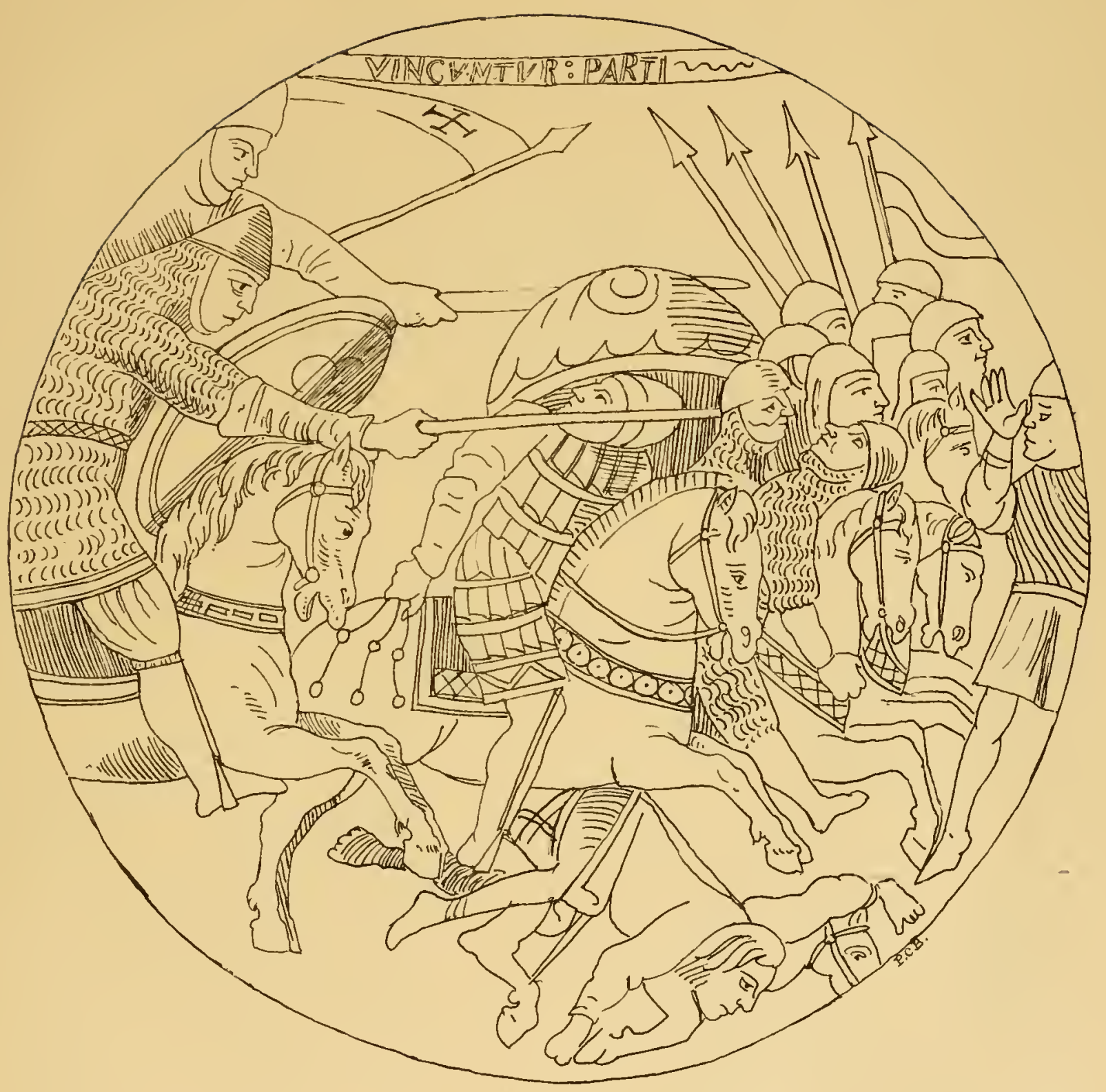





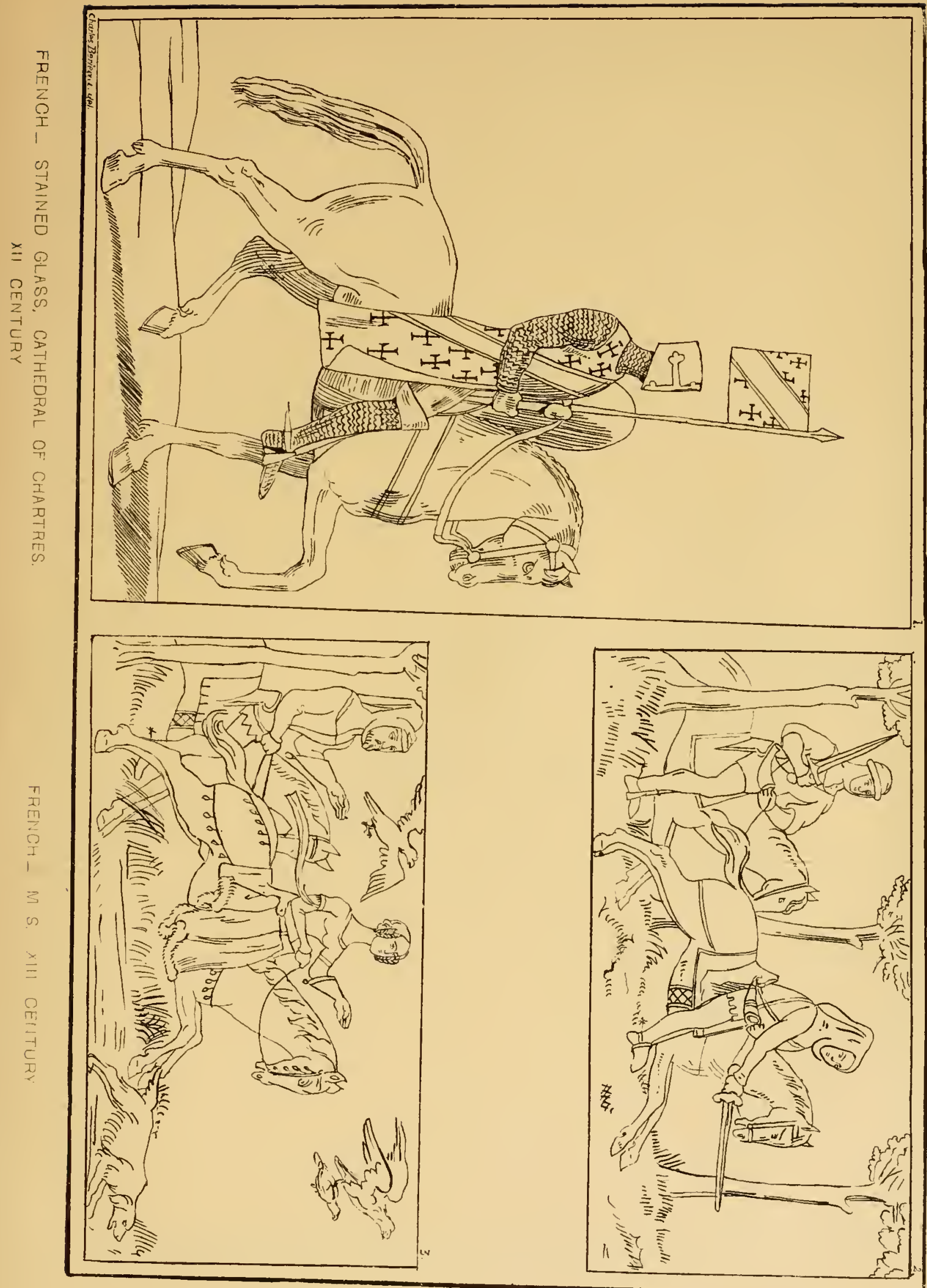





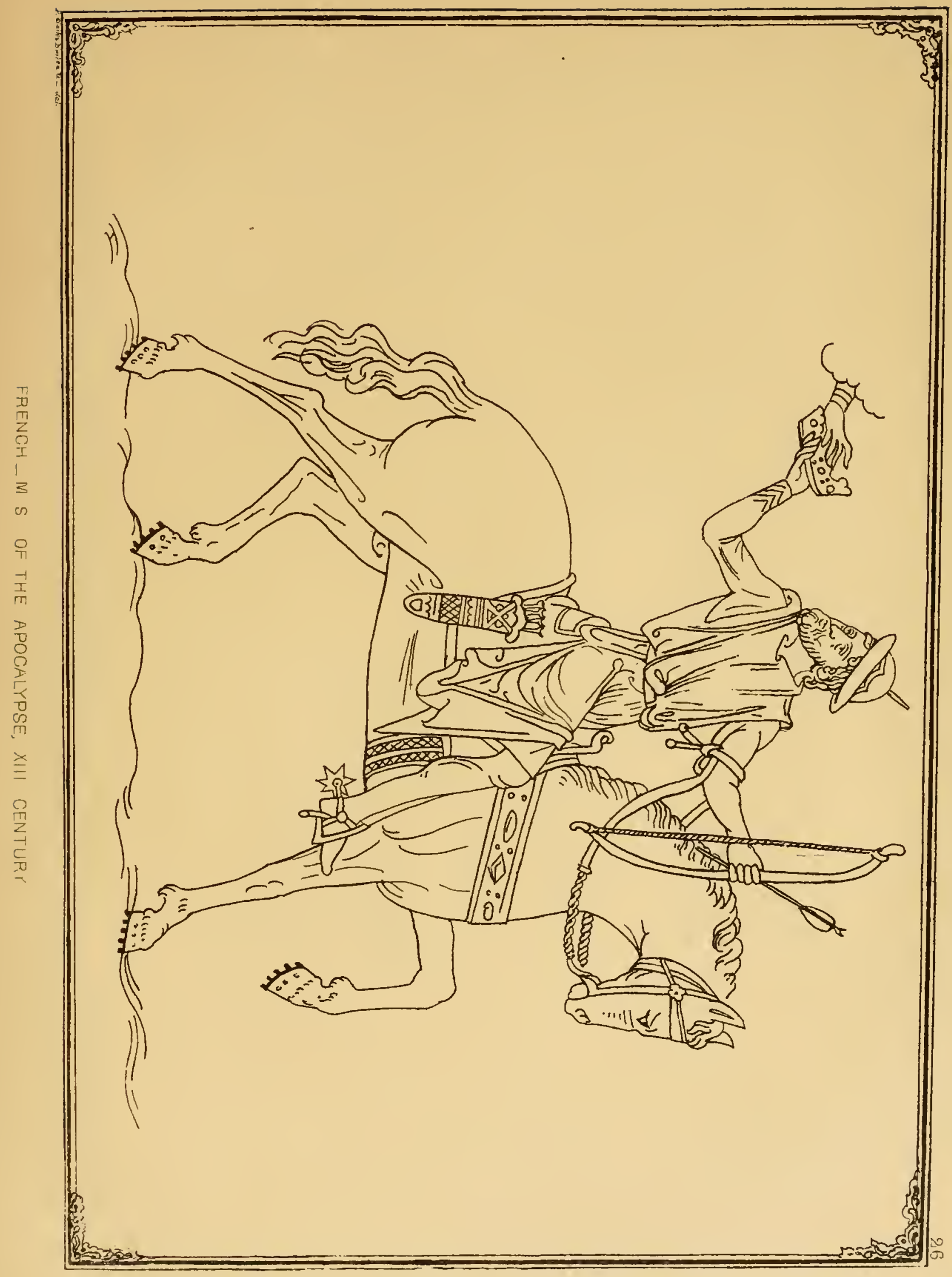





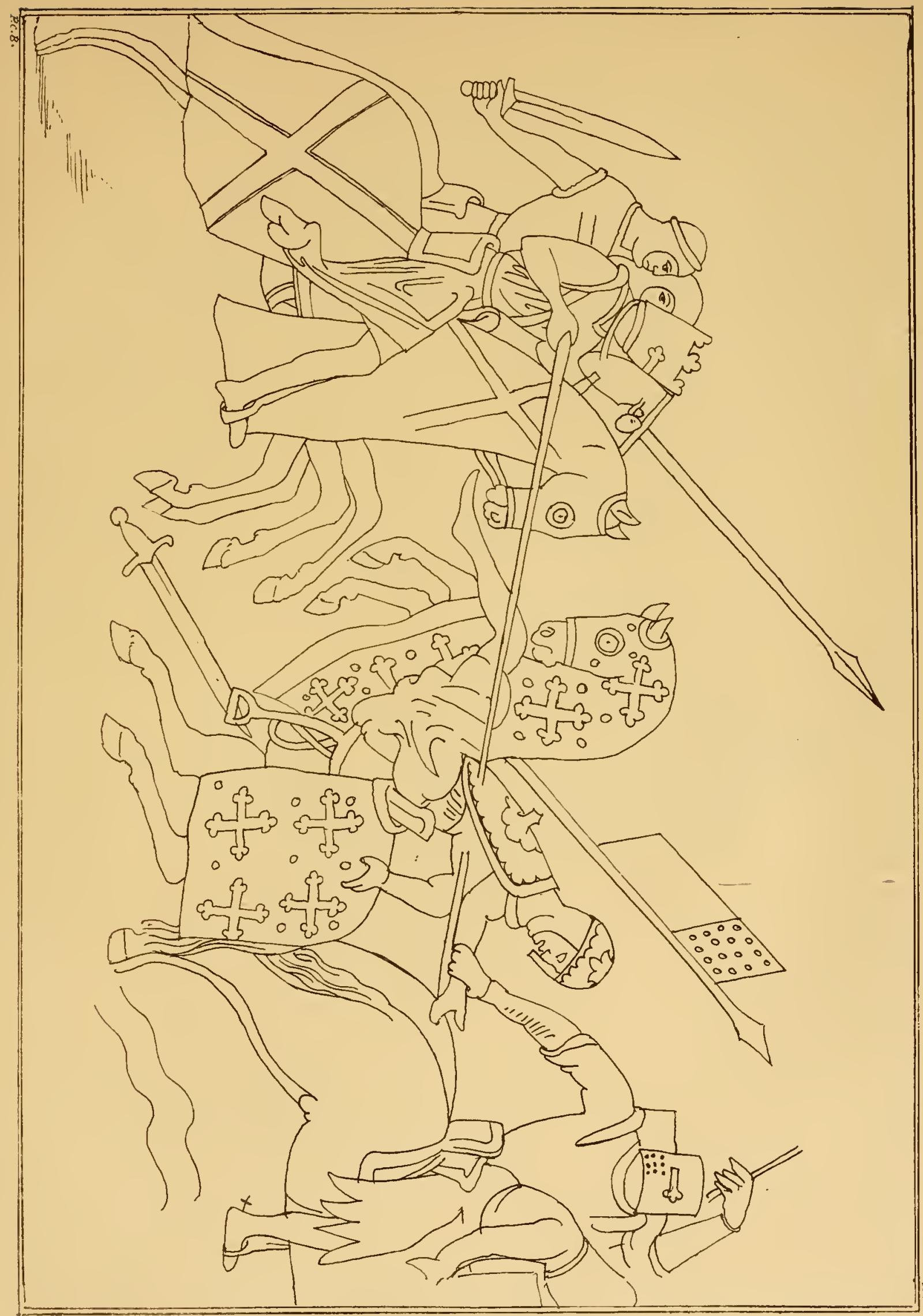





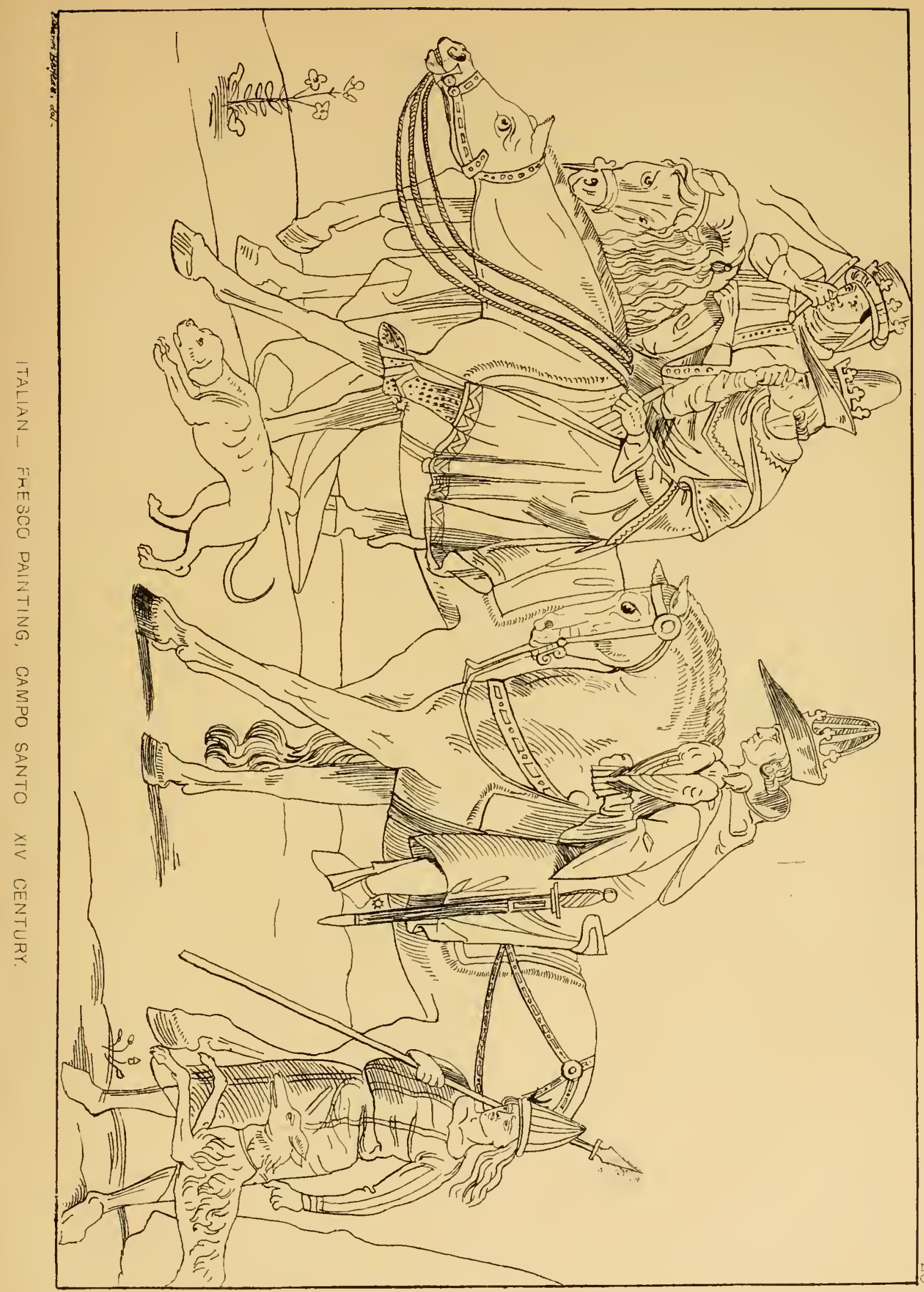





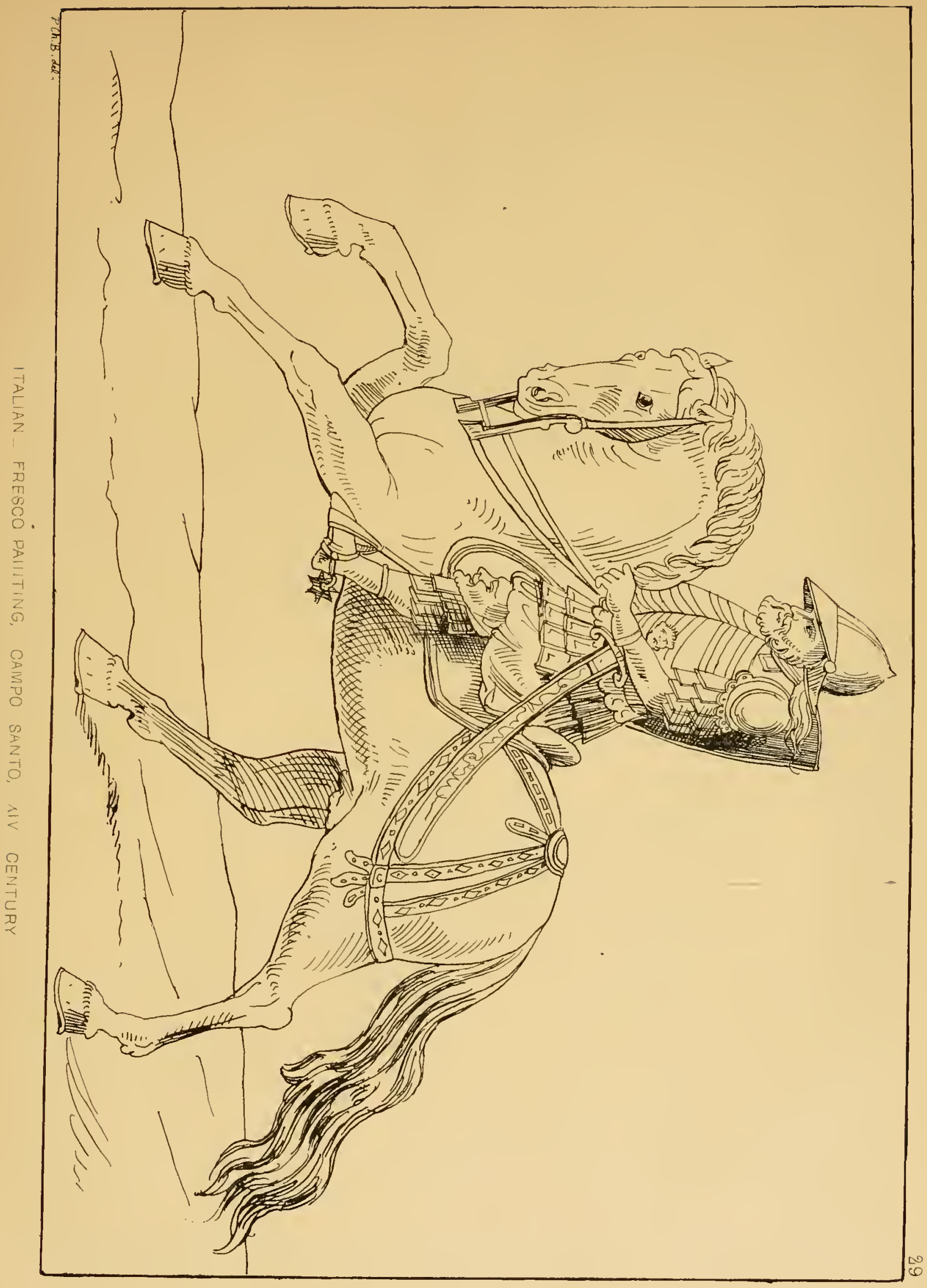





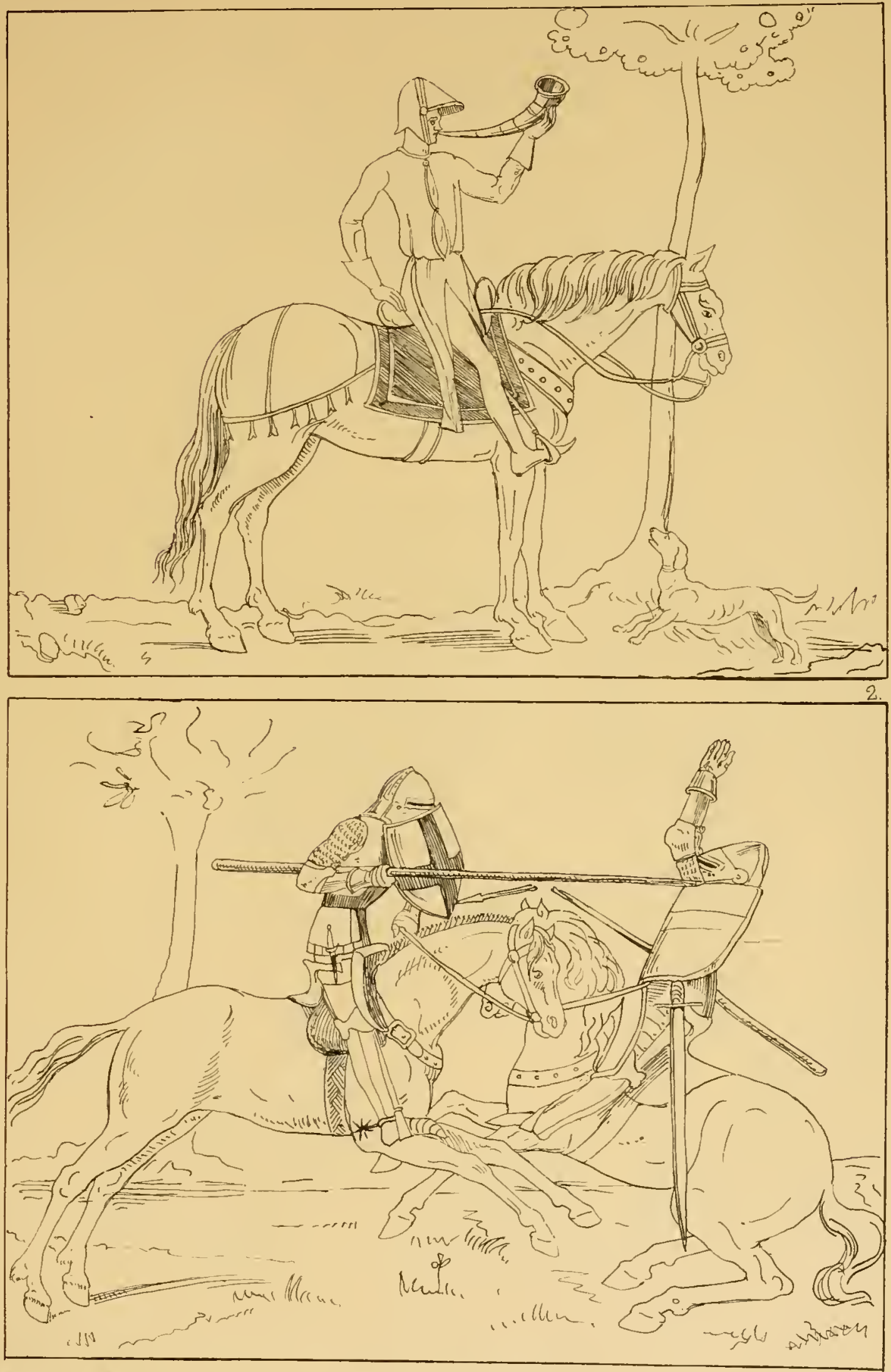





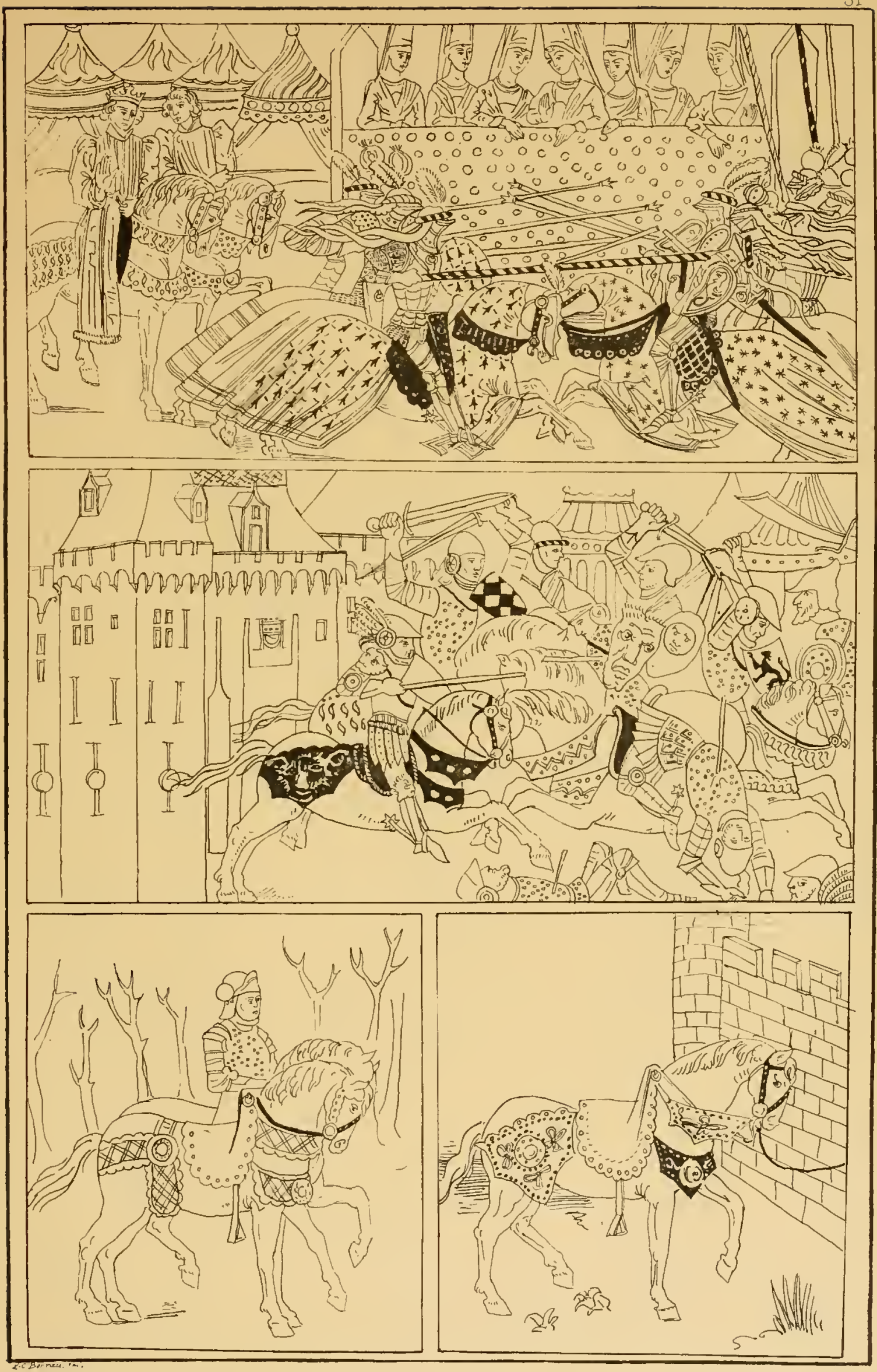





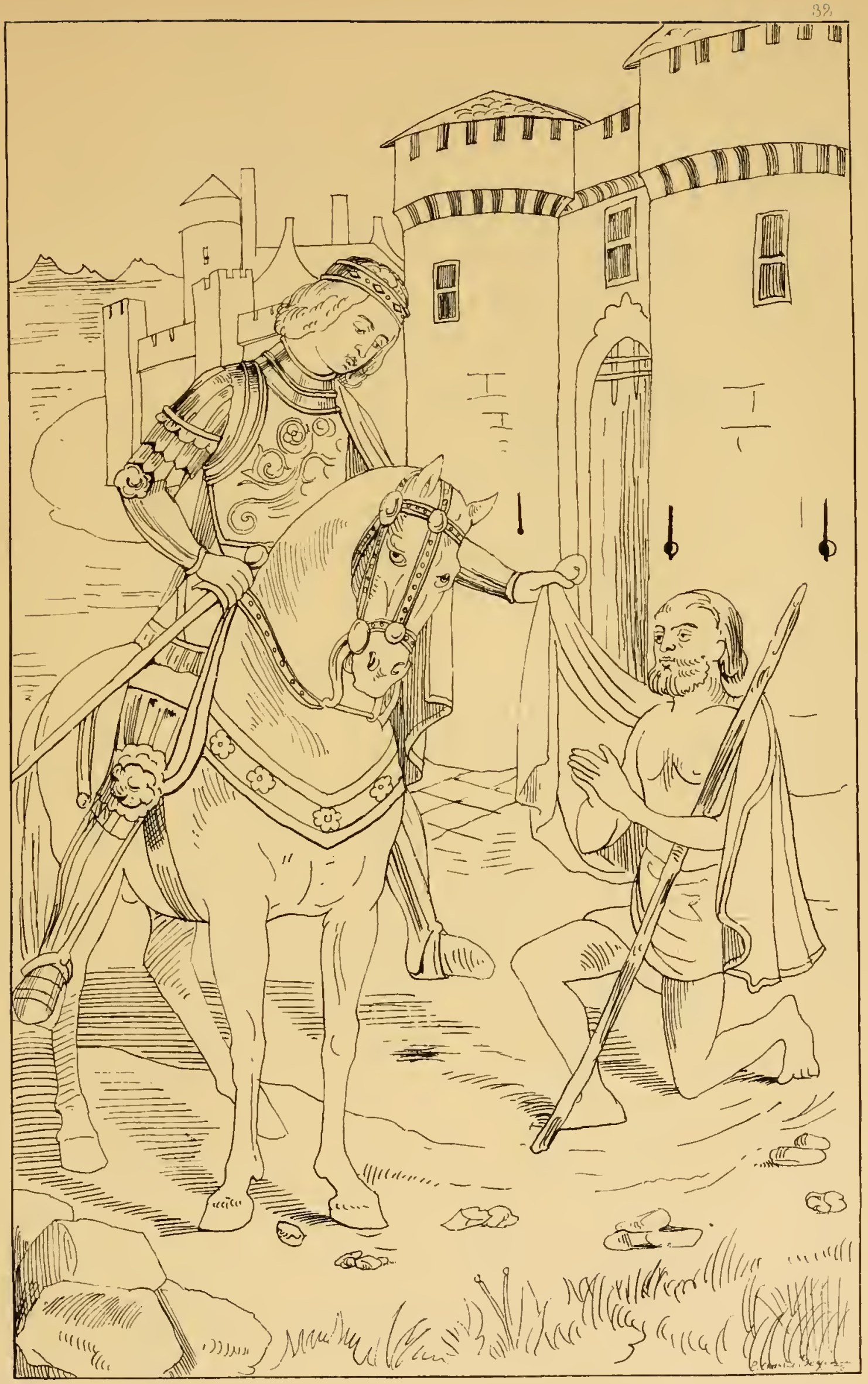




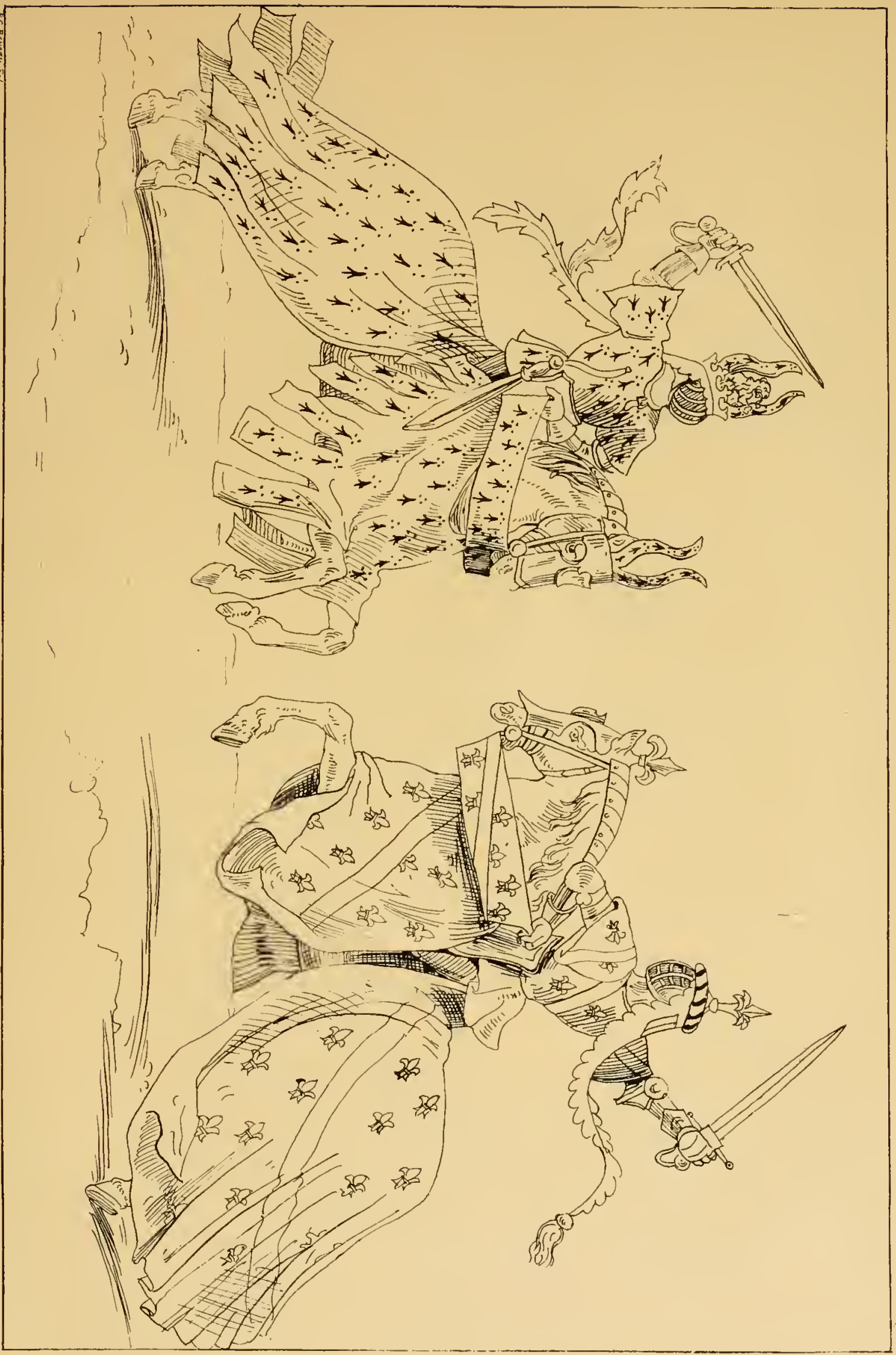





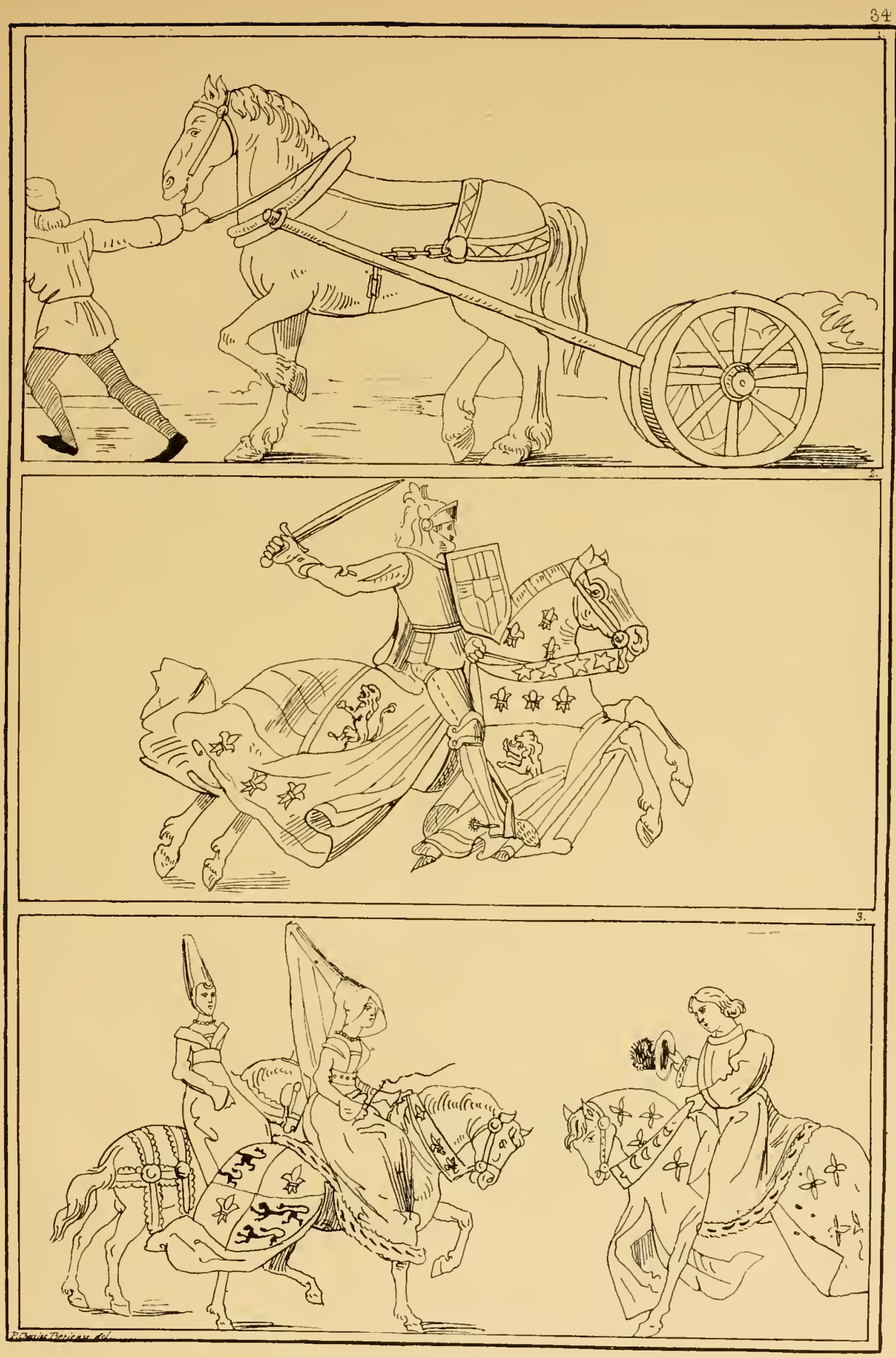





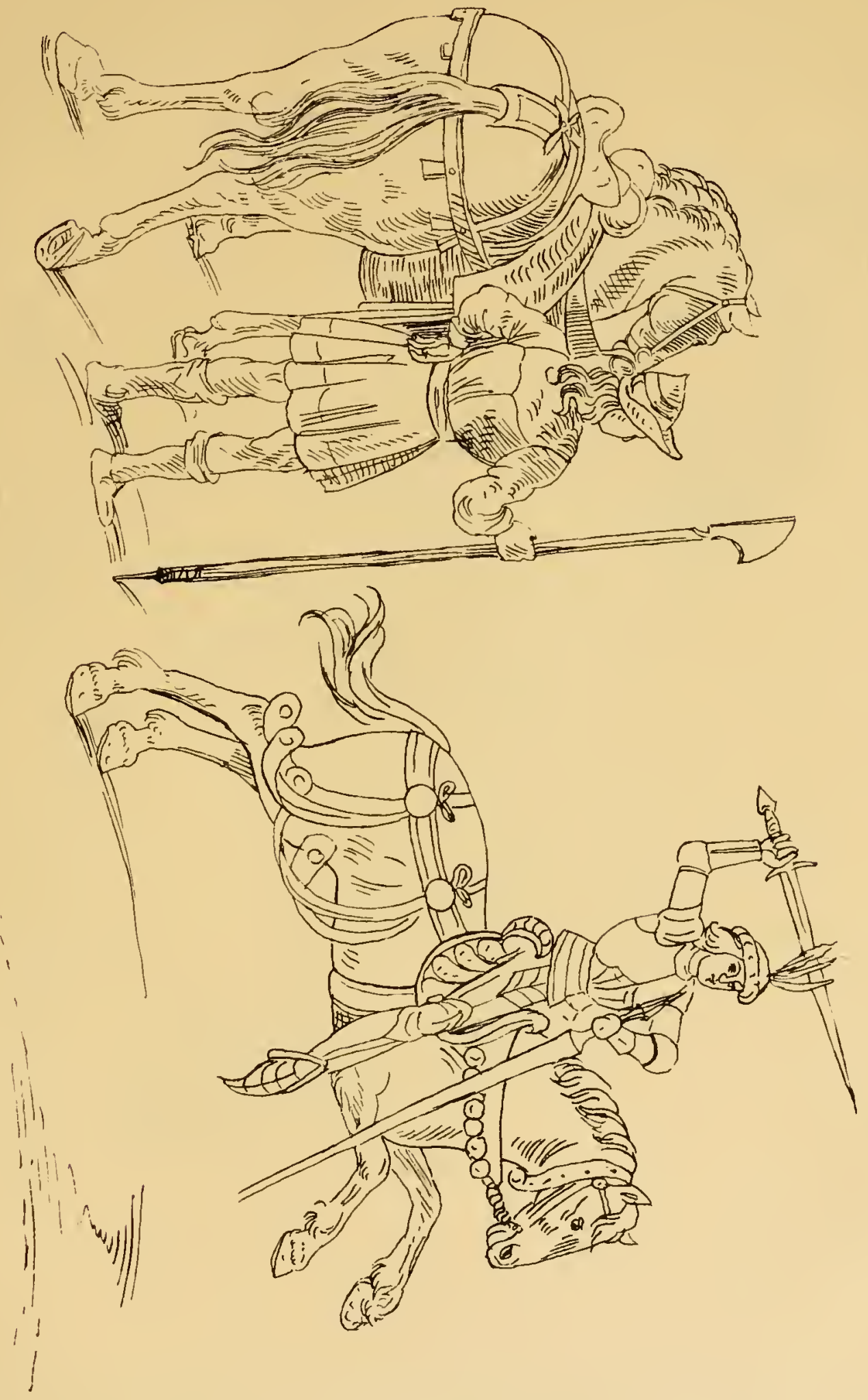





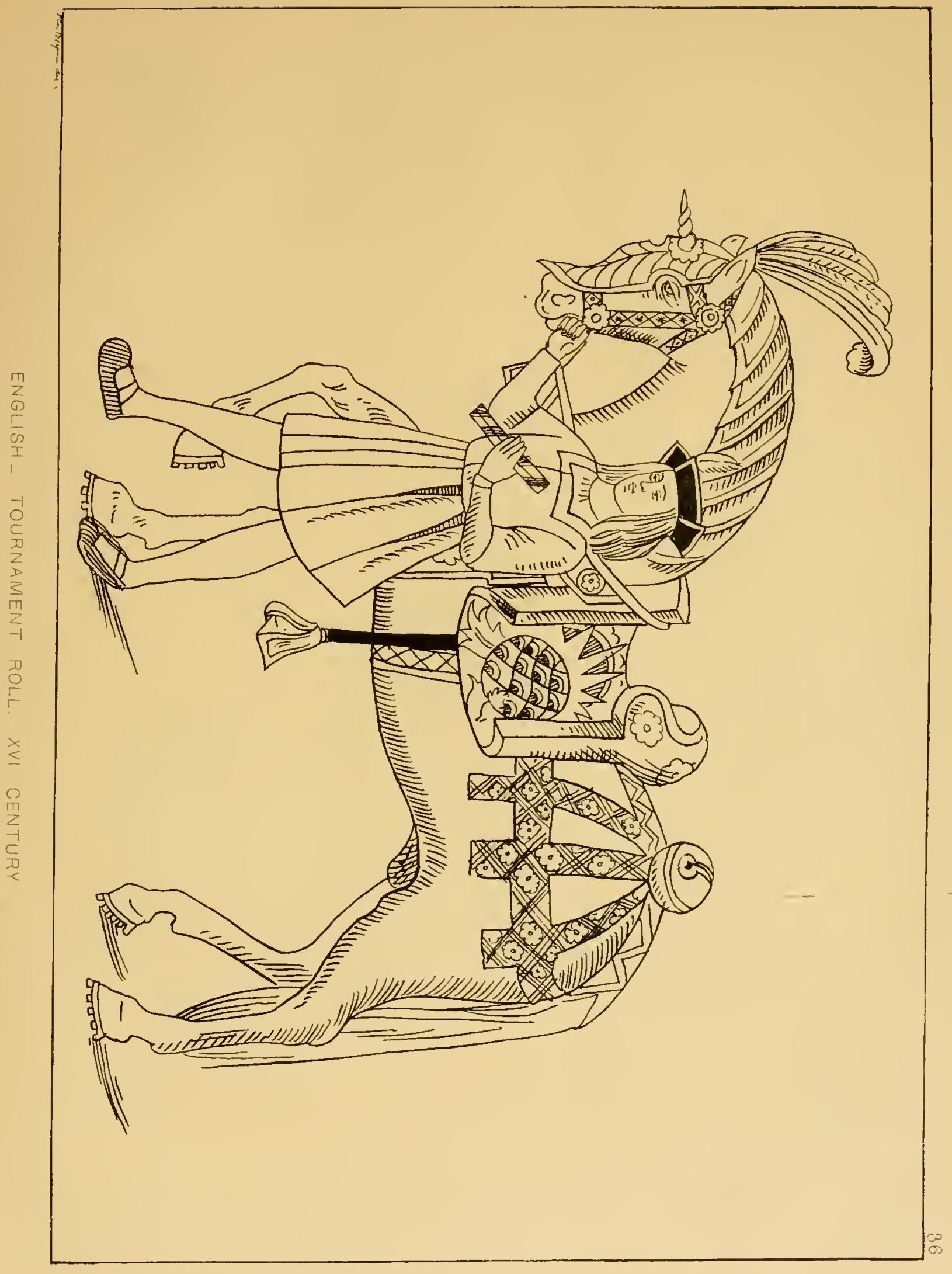




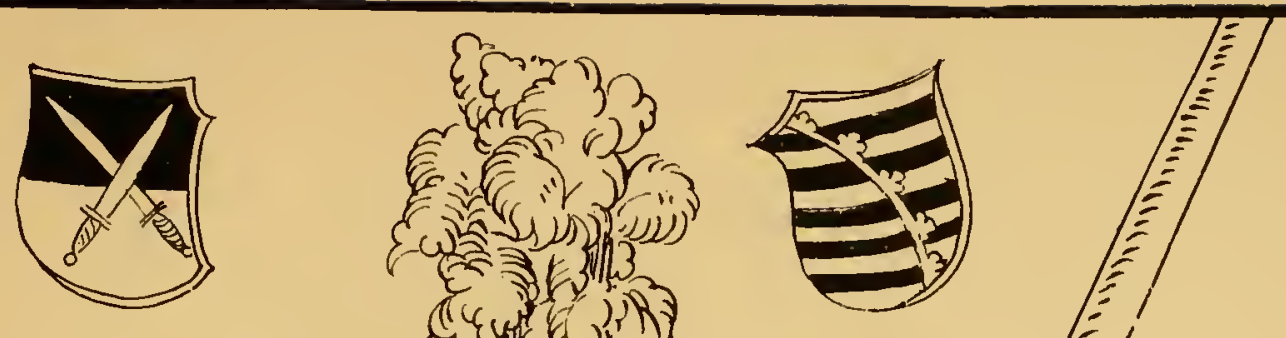

Tim

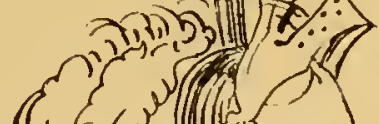
sis (c) (c) (i) (1) (1) J ( j)

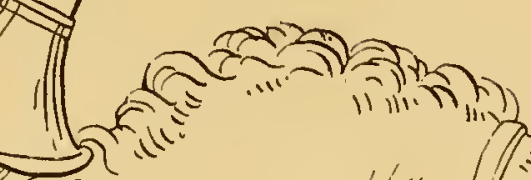

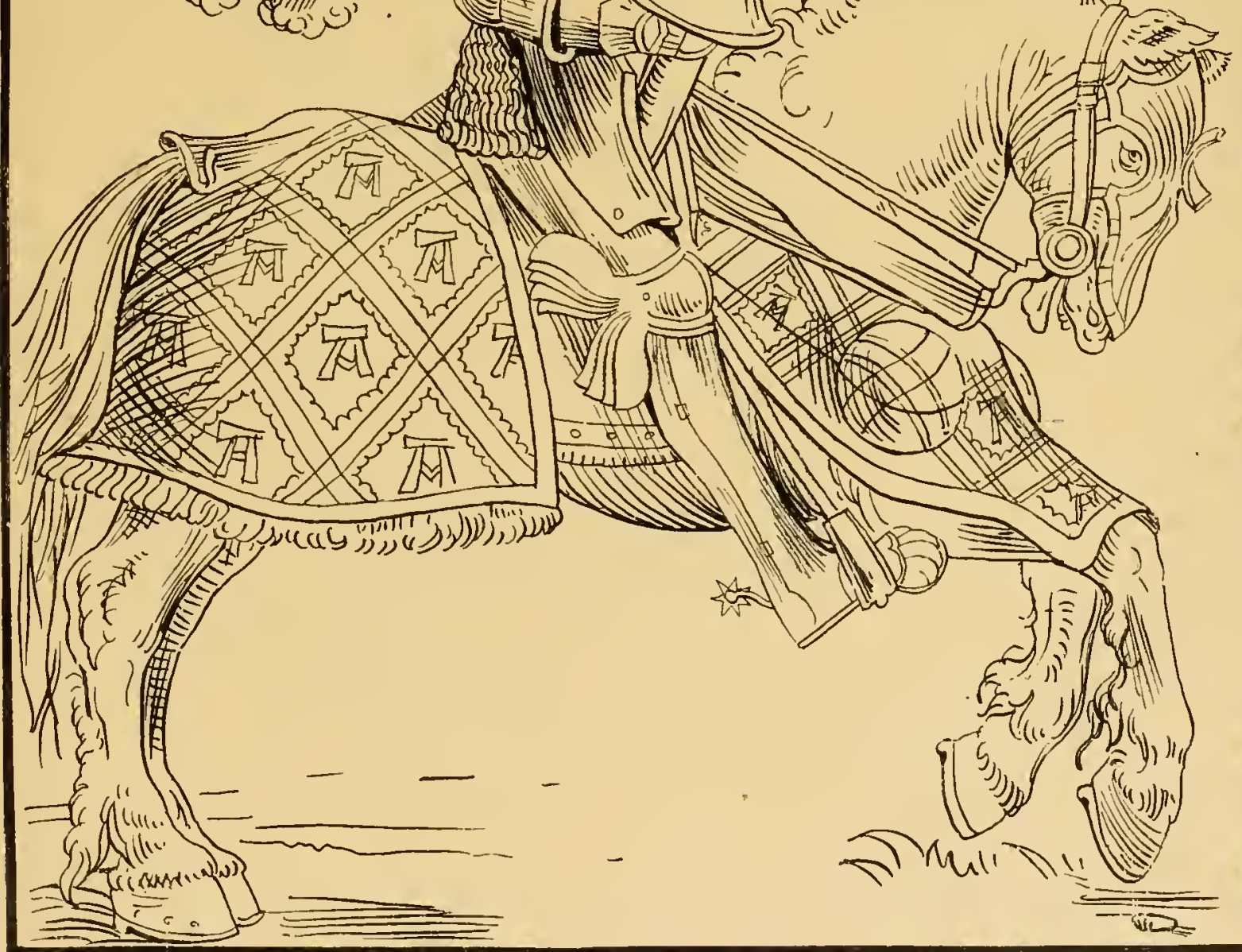





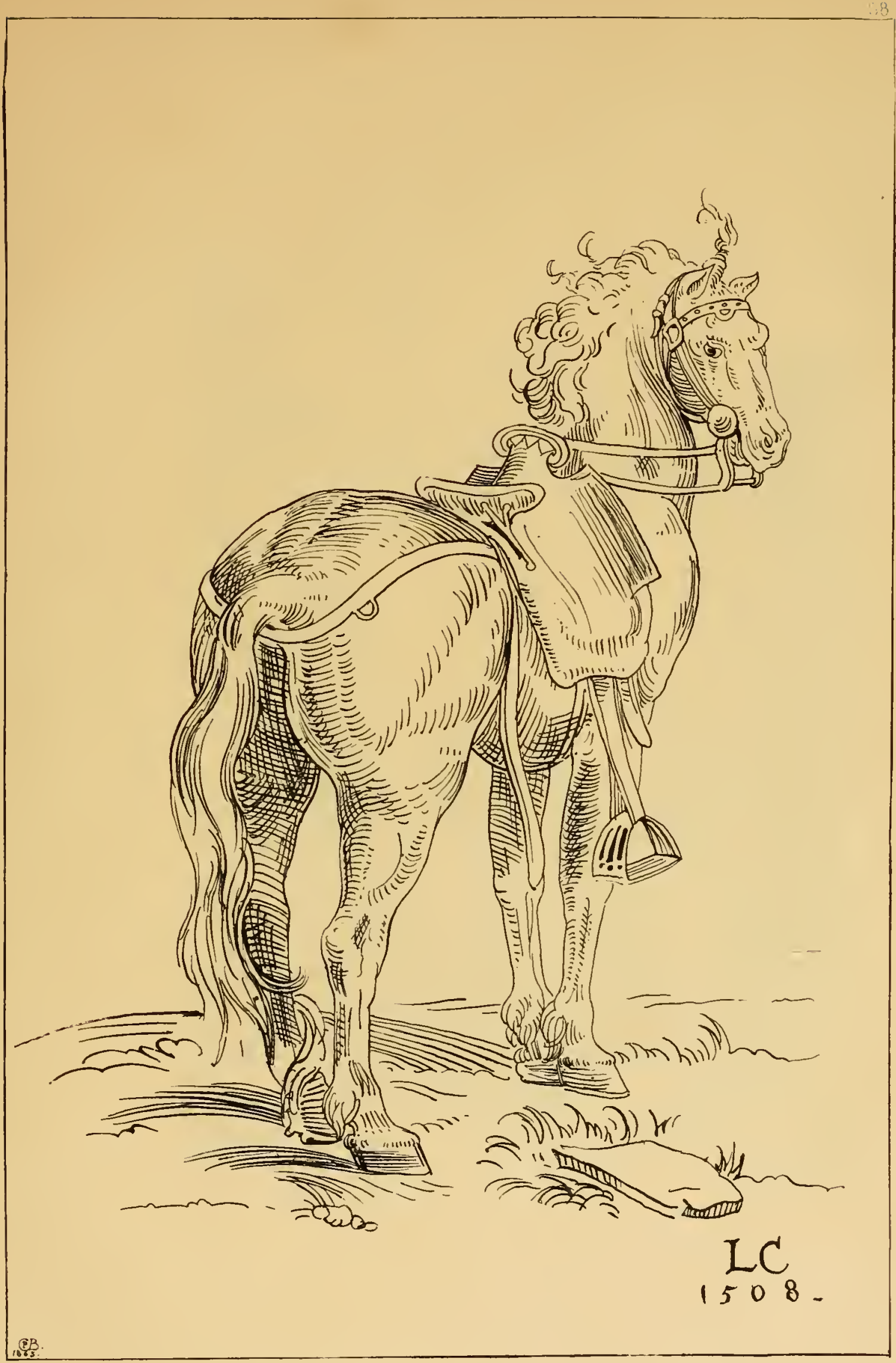





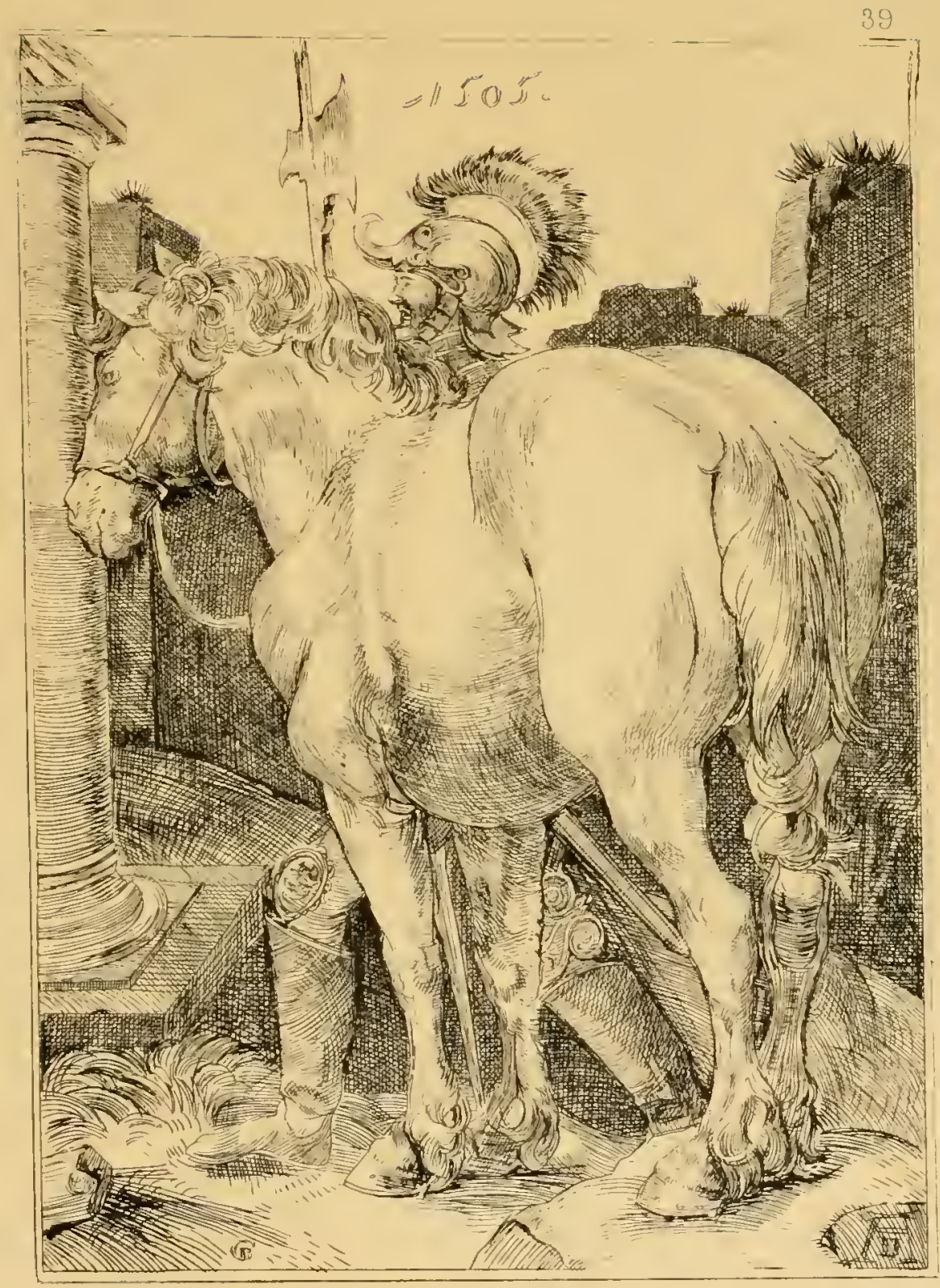

ALBERT DURER, 1505 



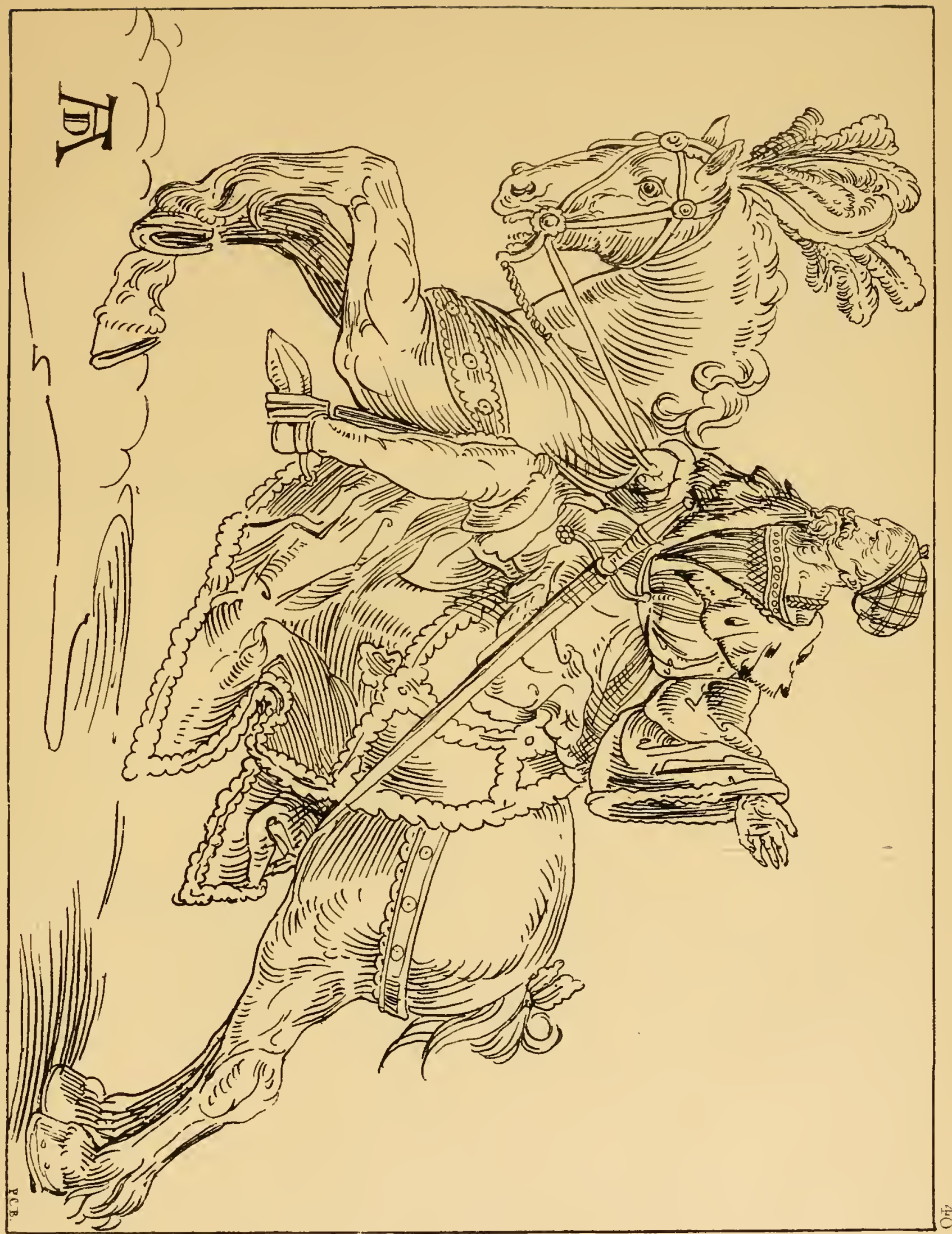





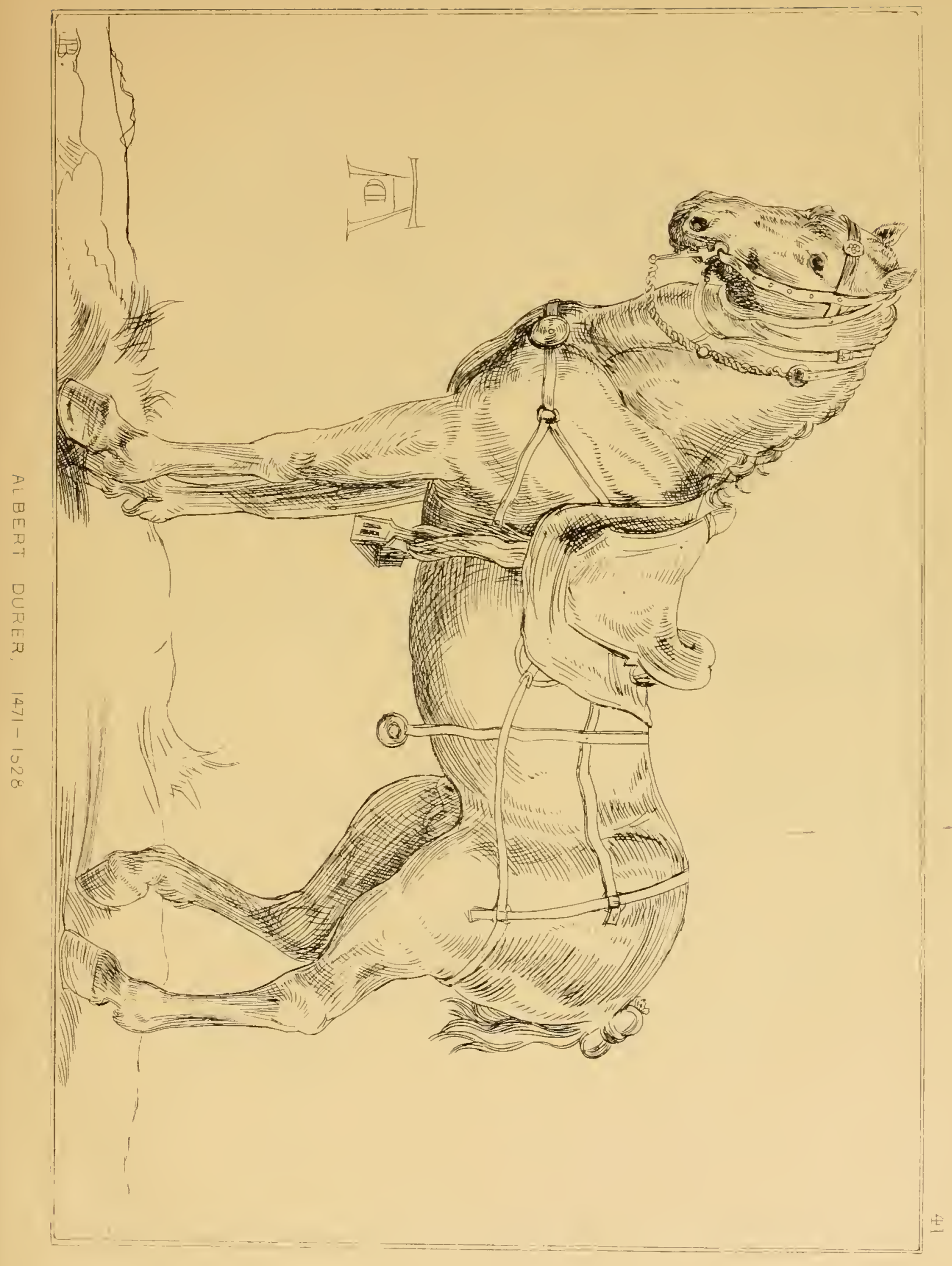





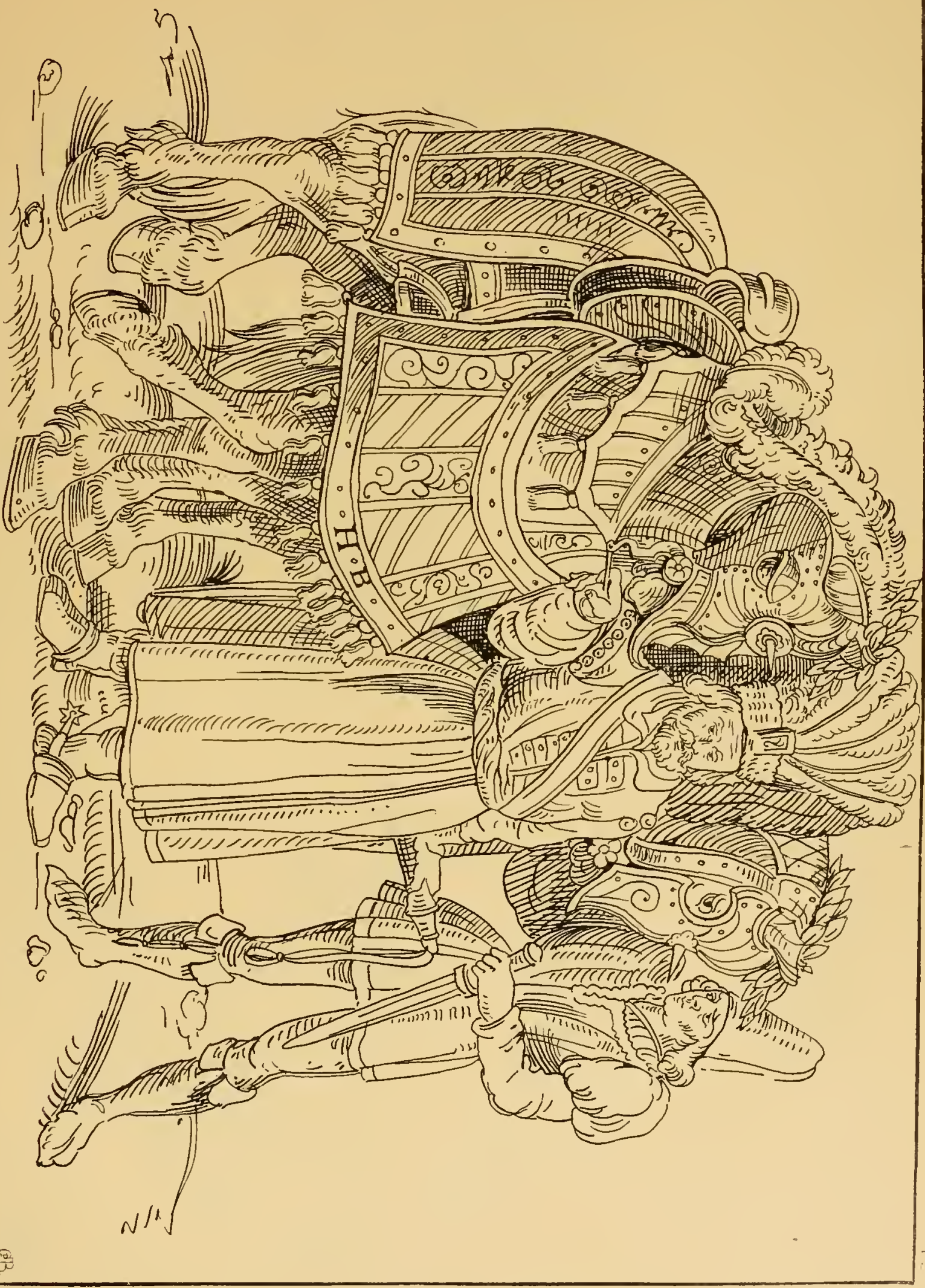





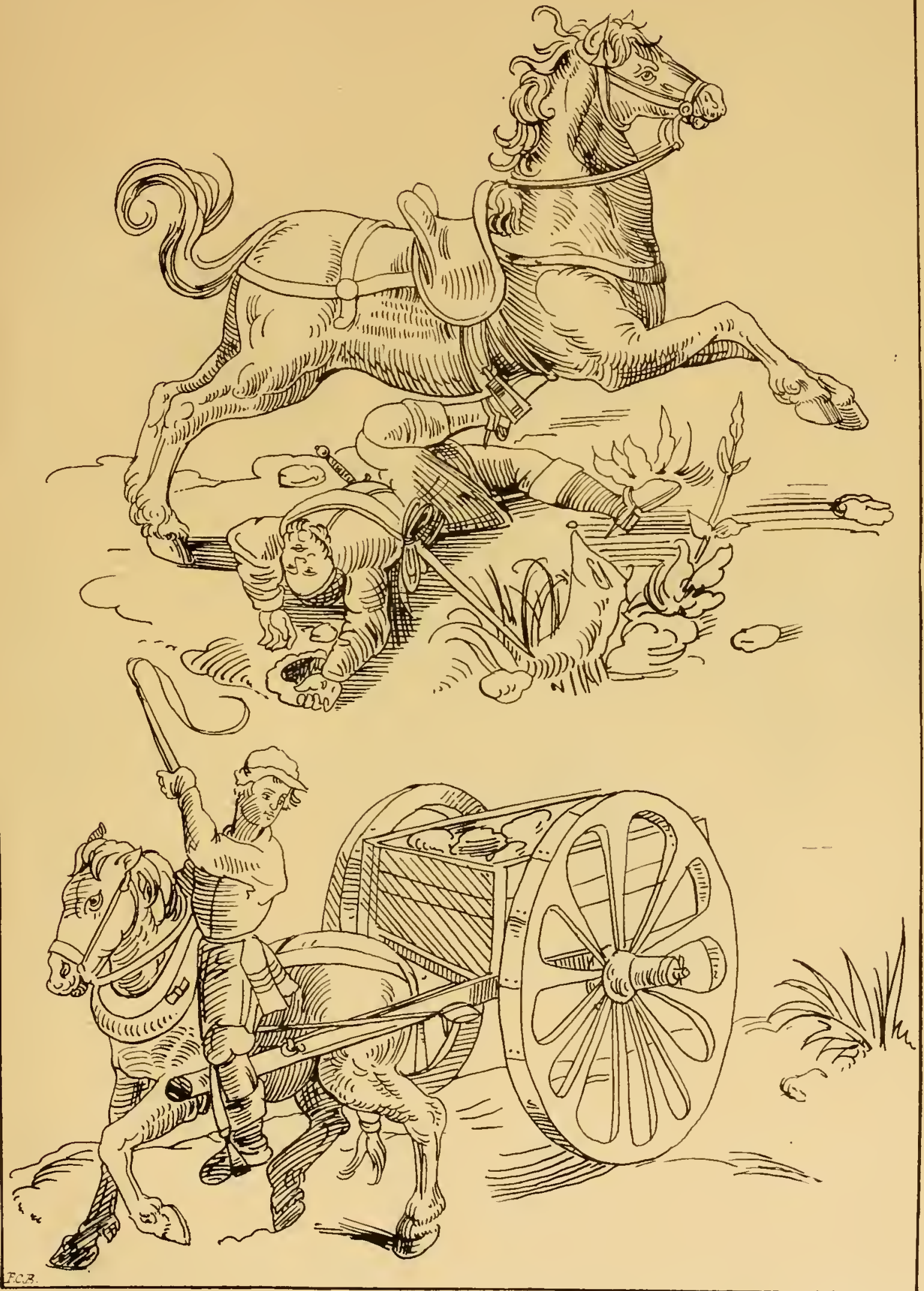





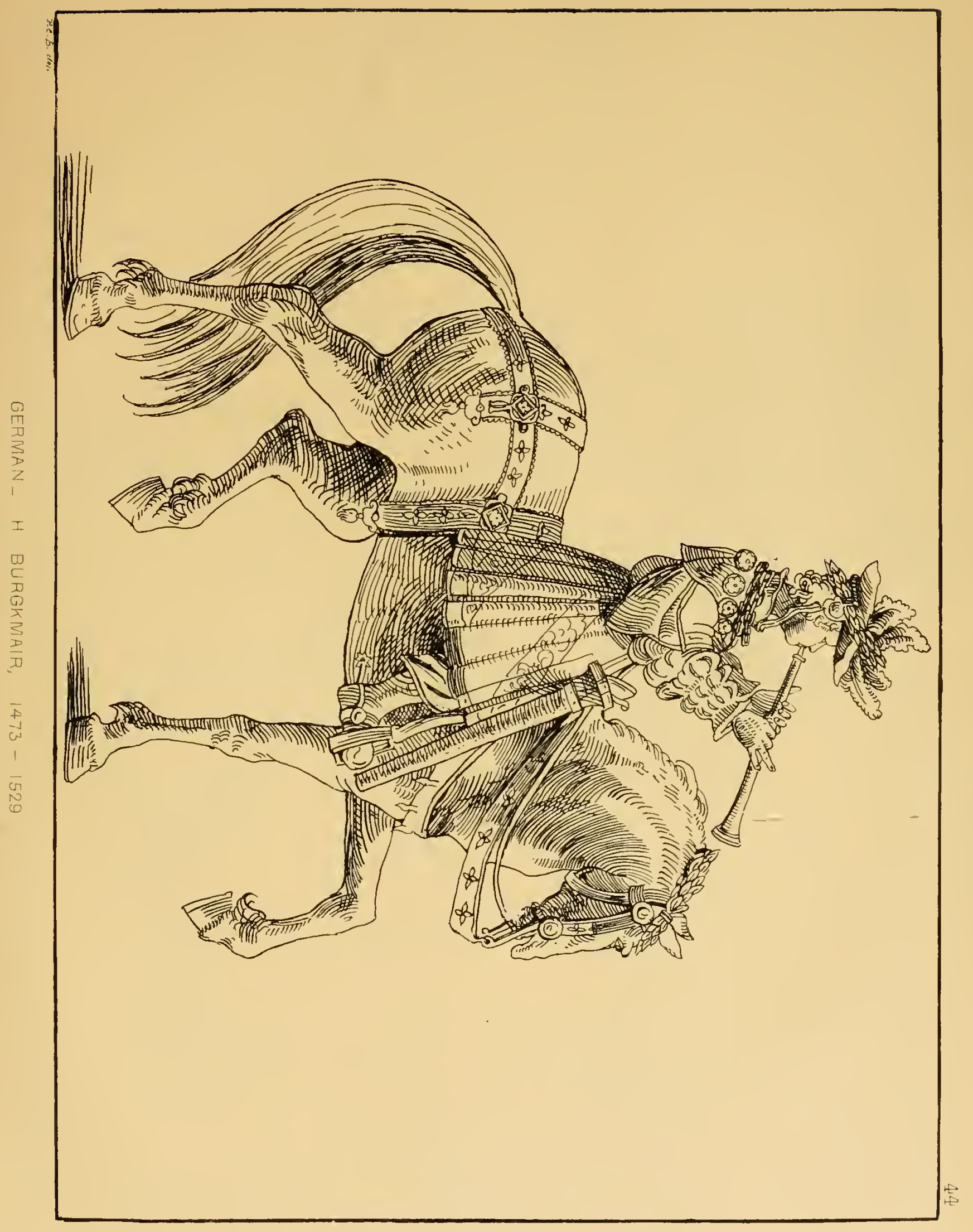





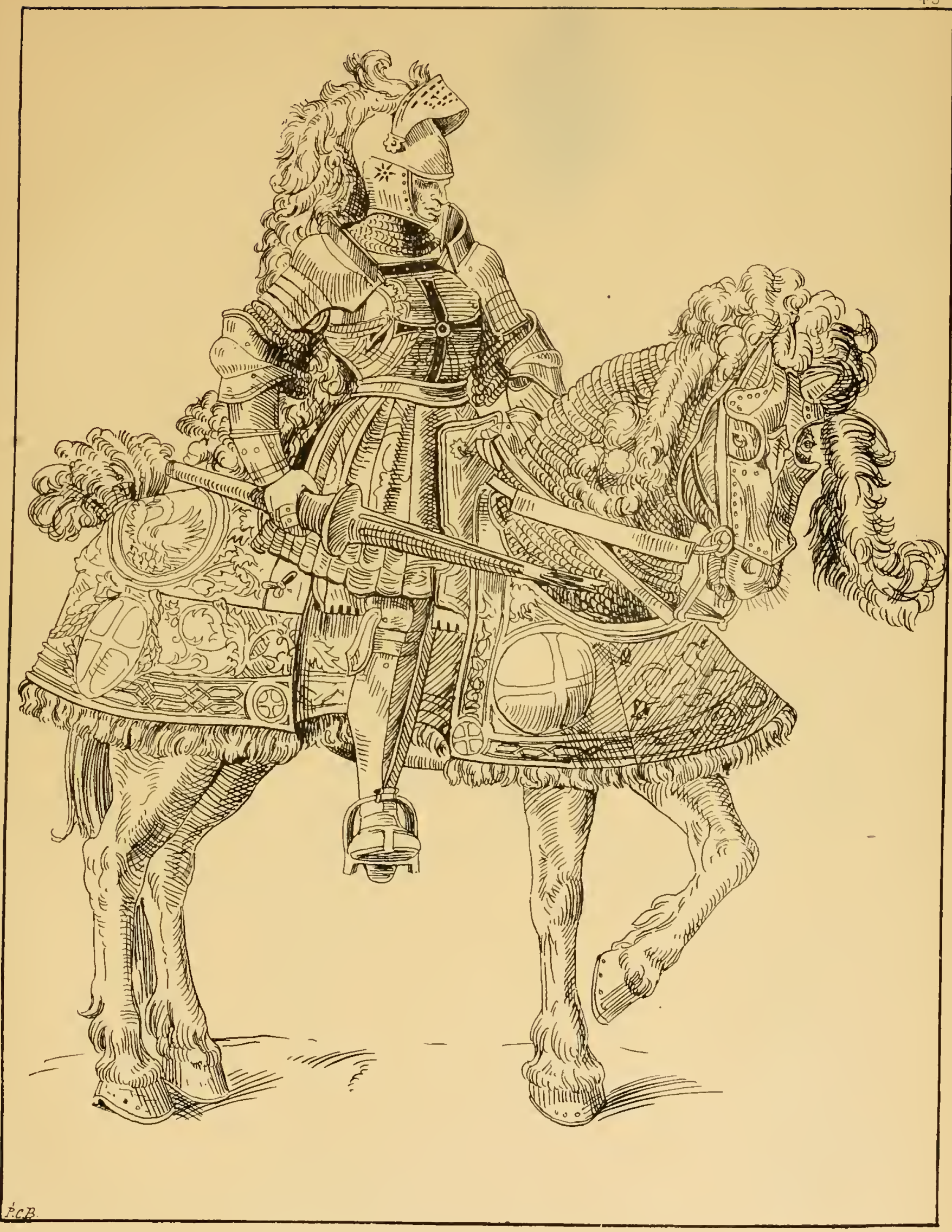





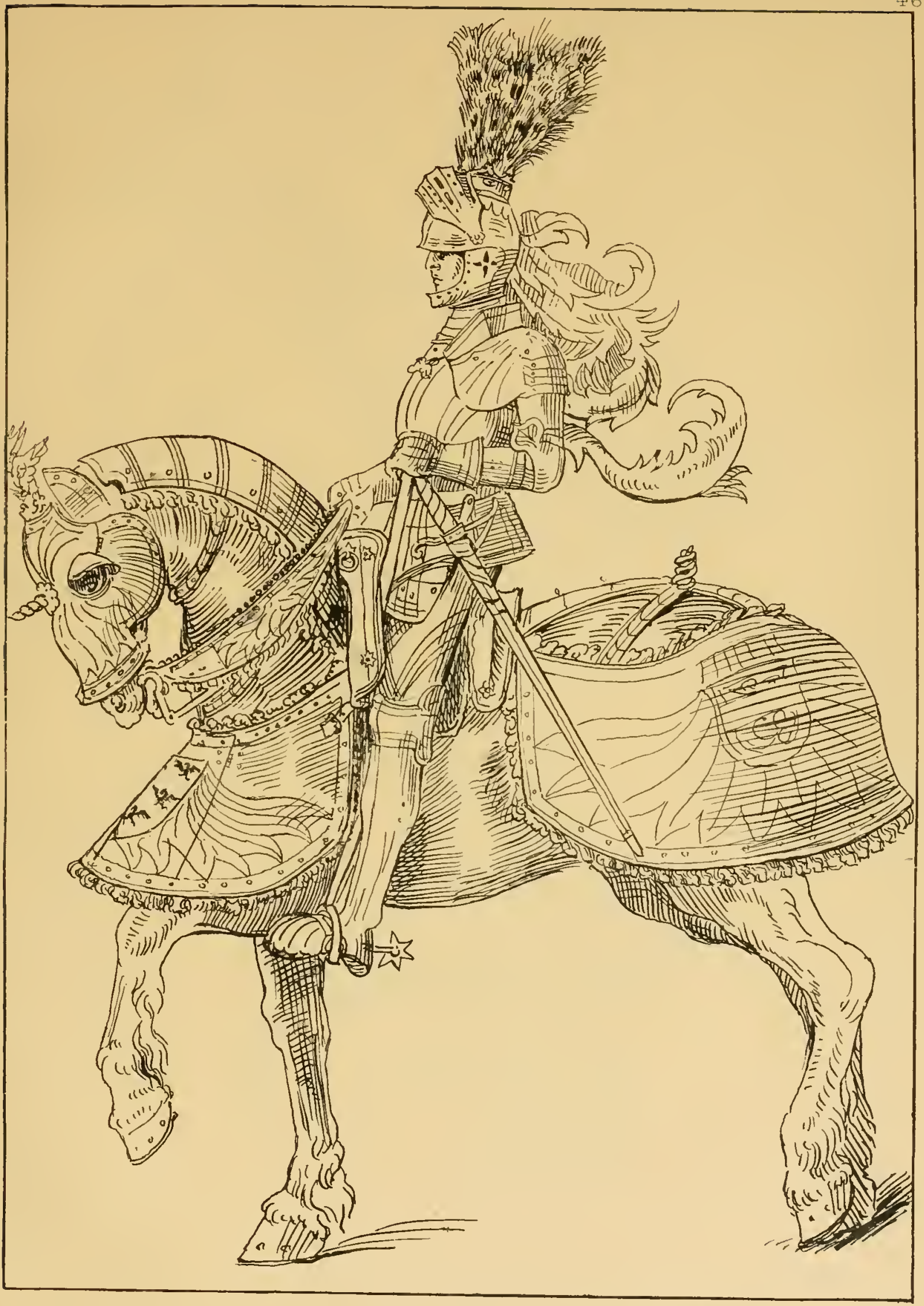





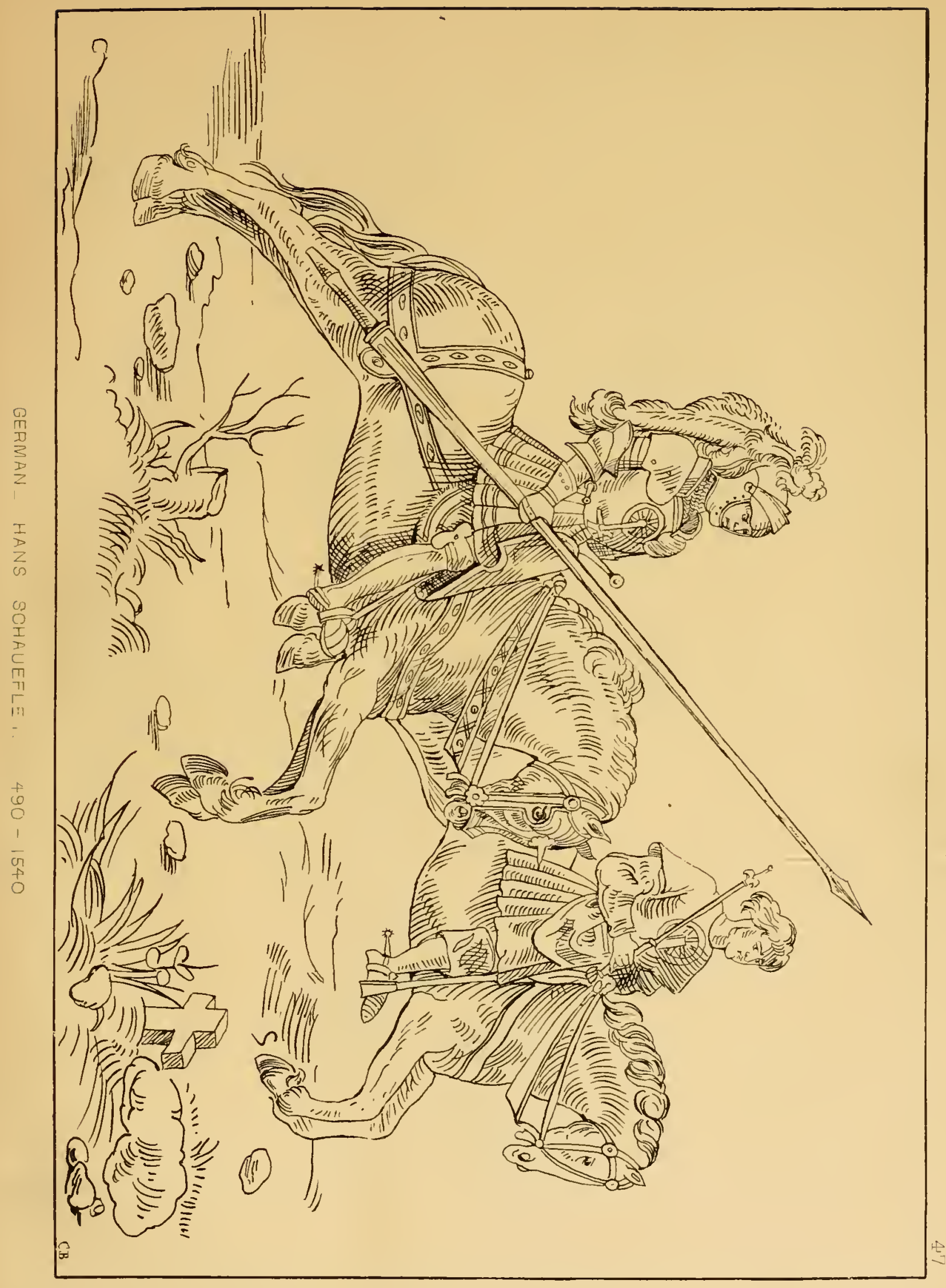





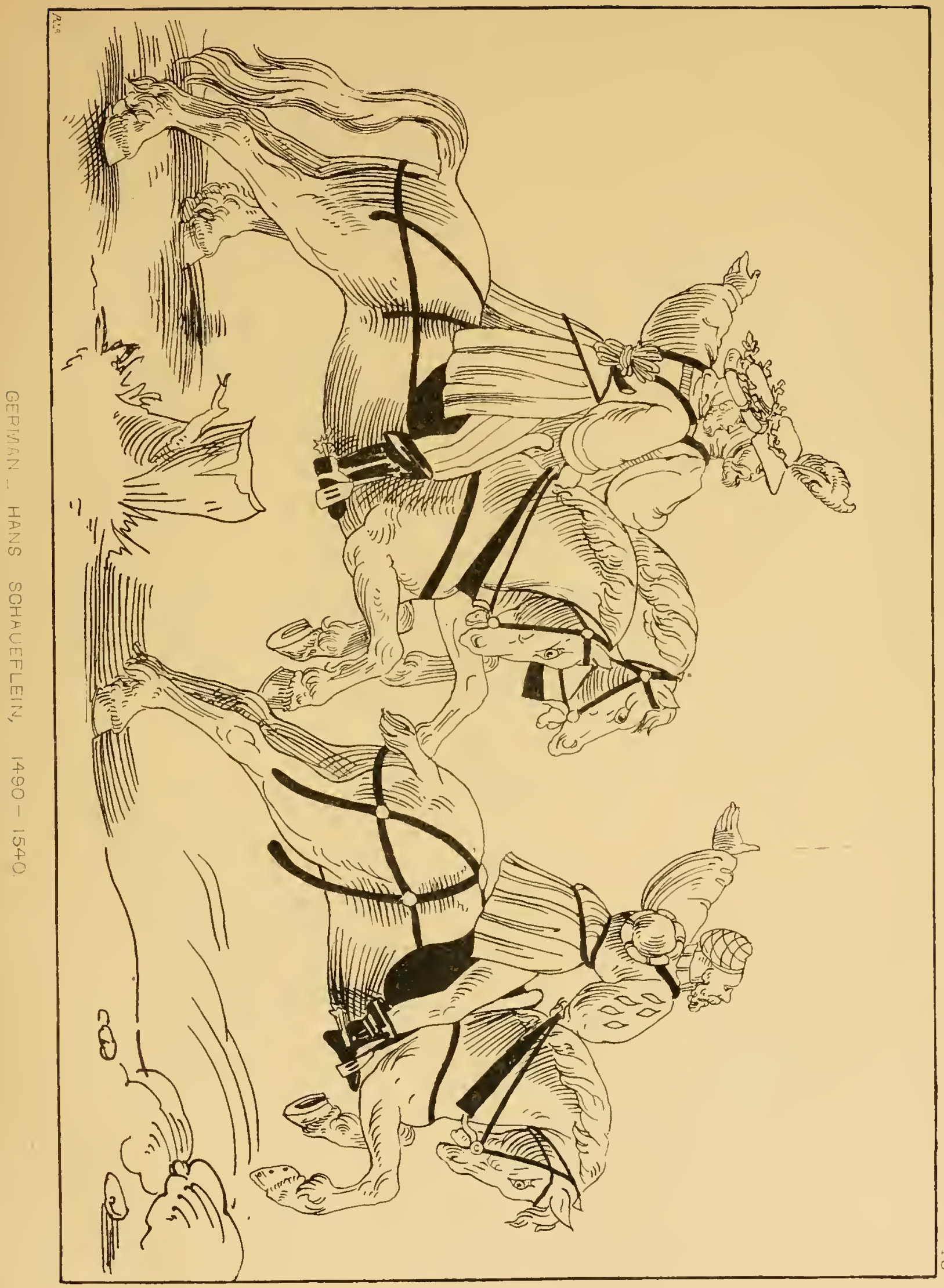





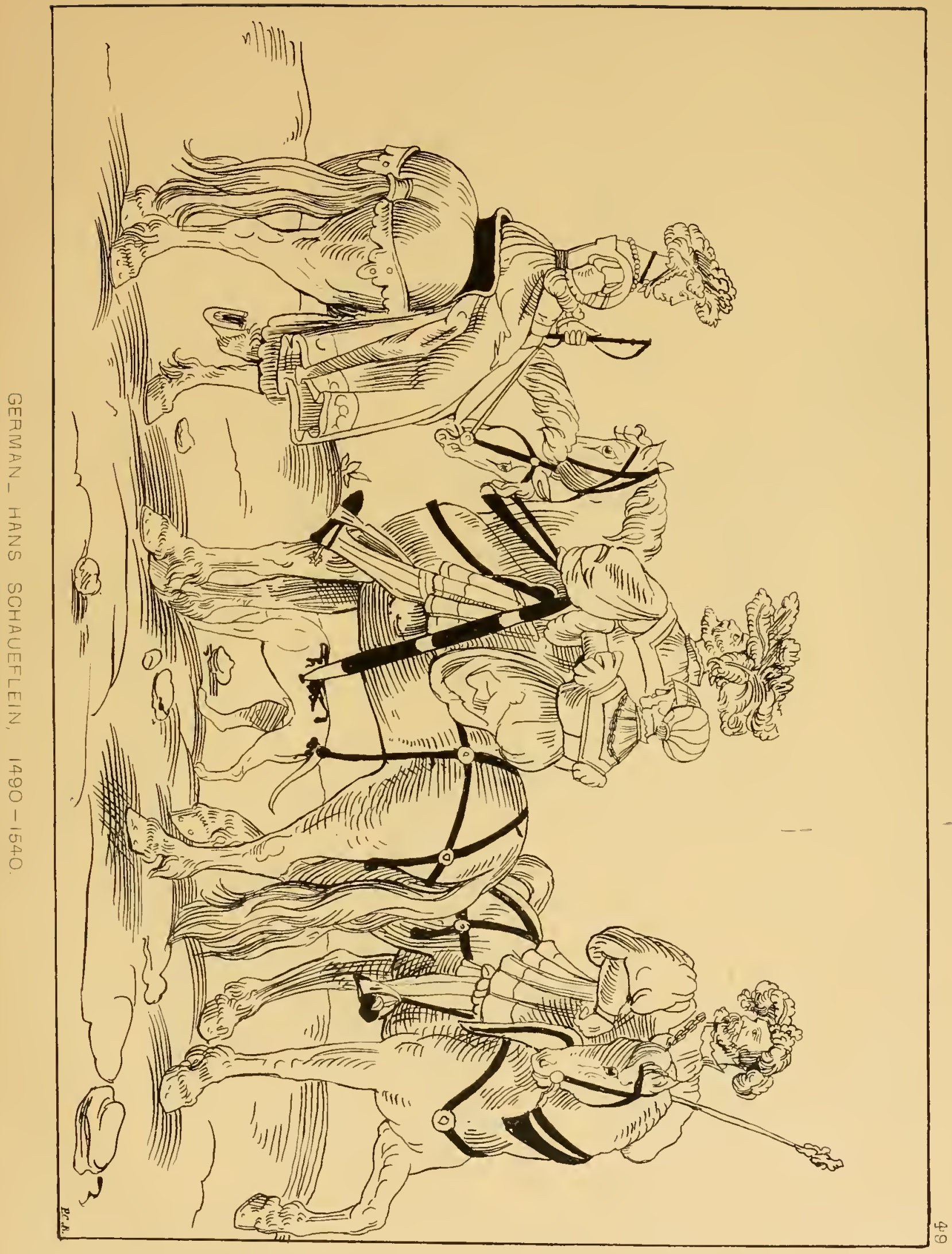





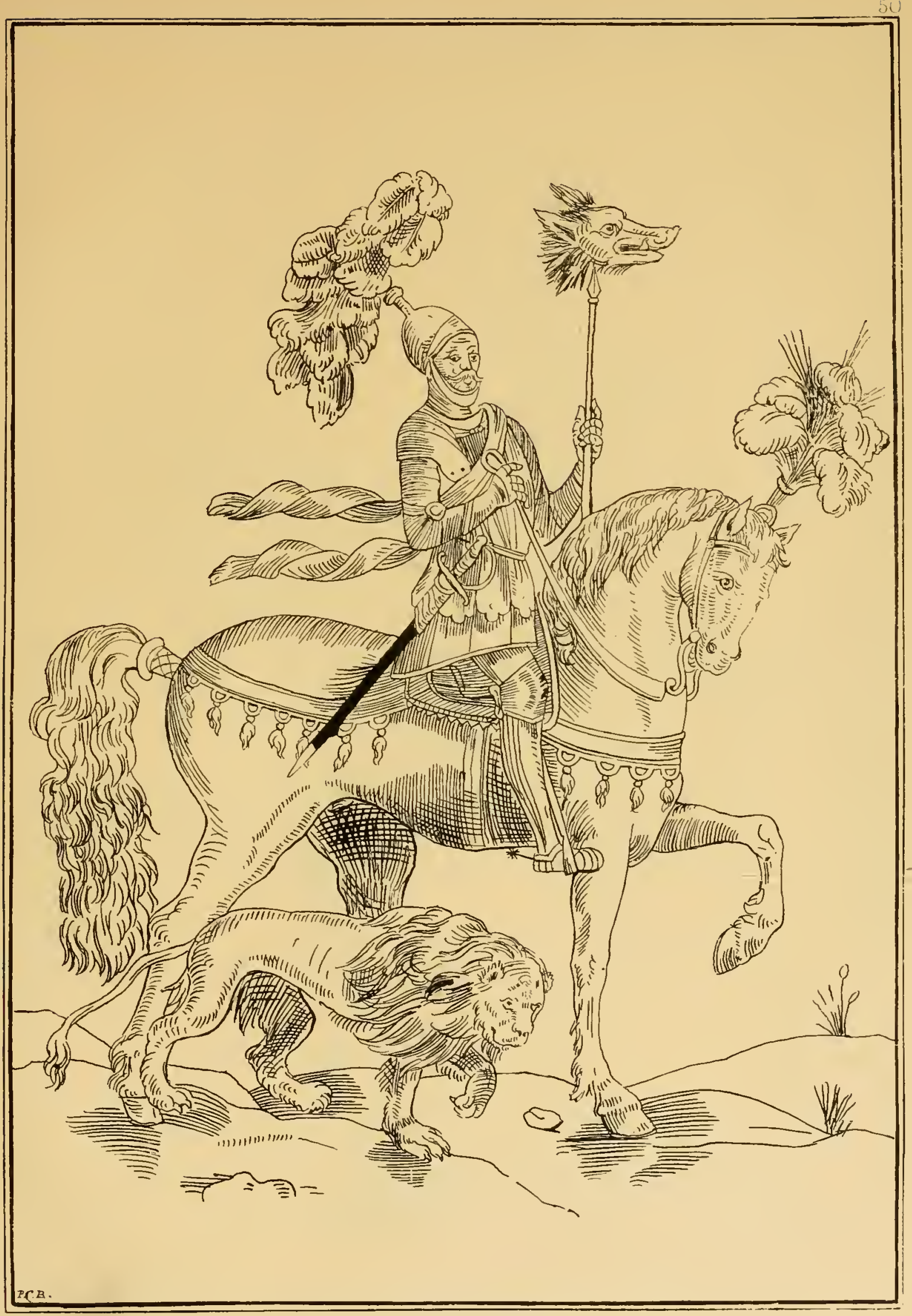





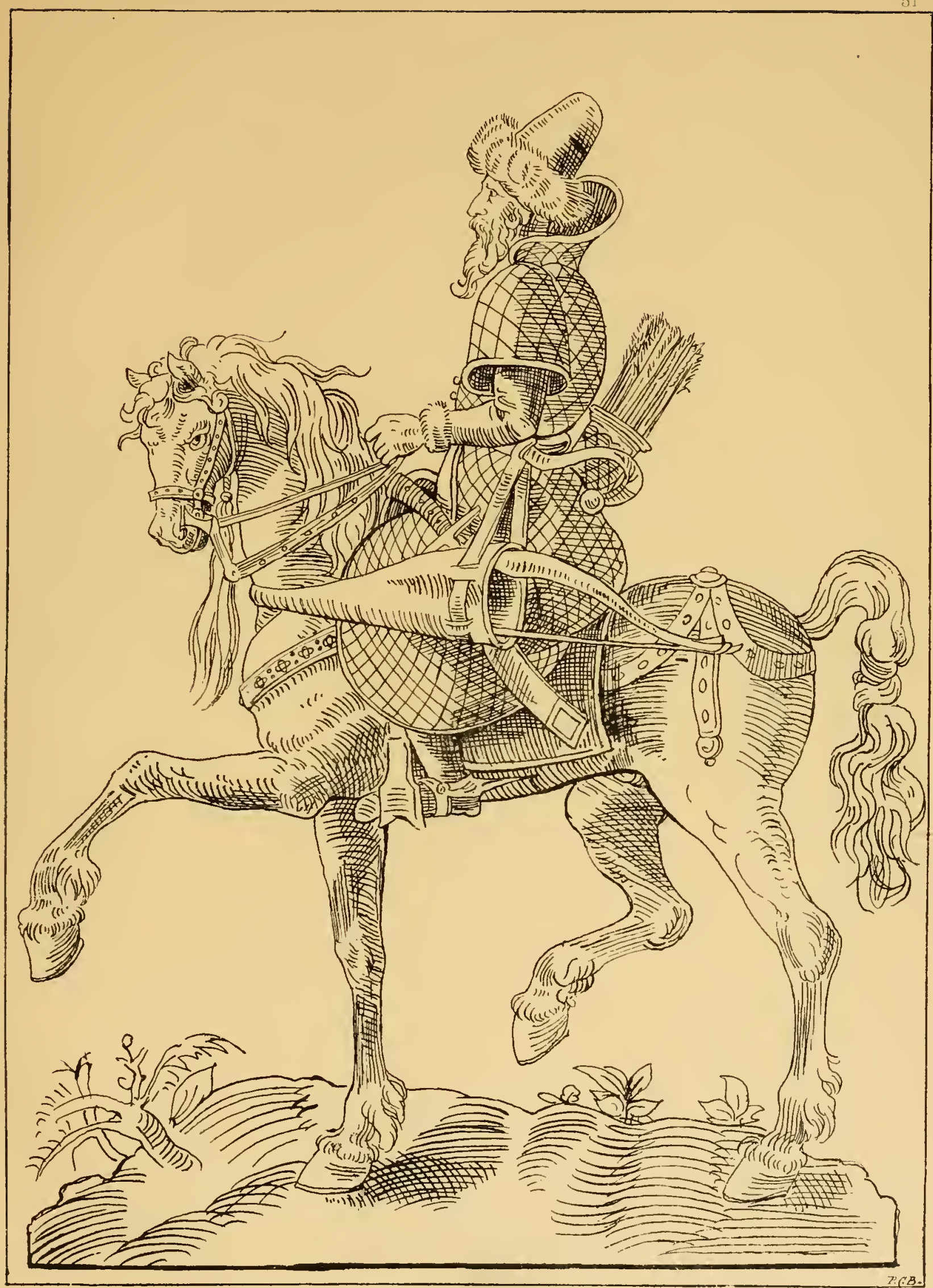





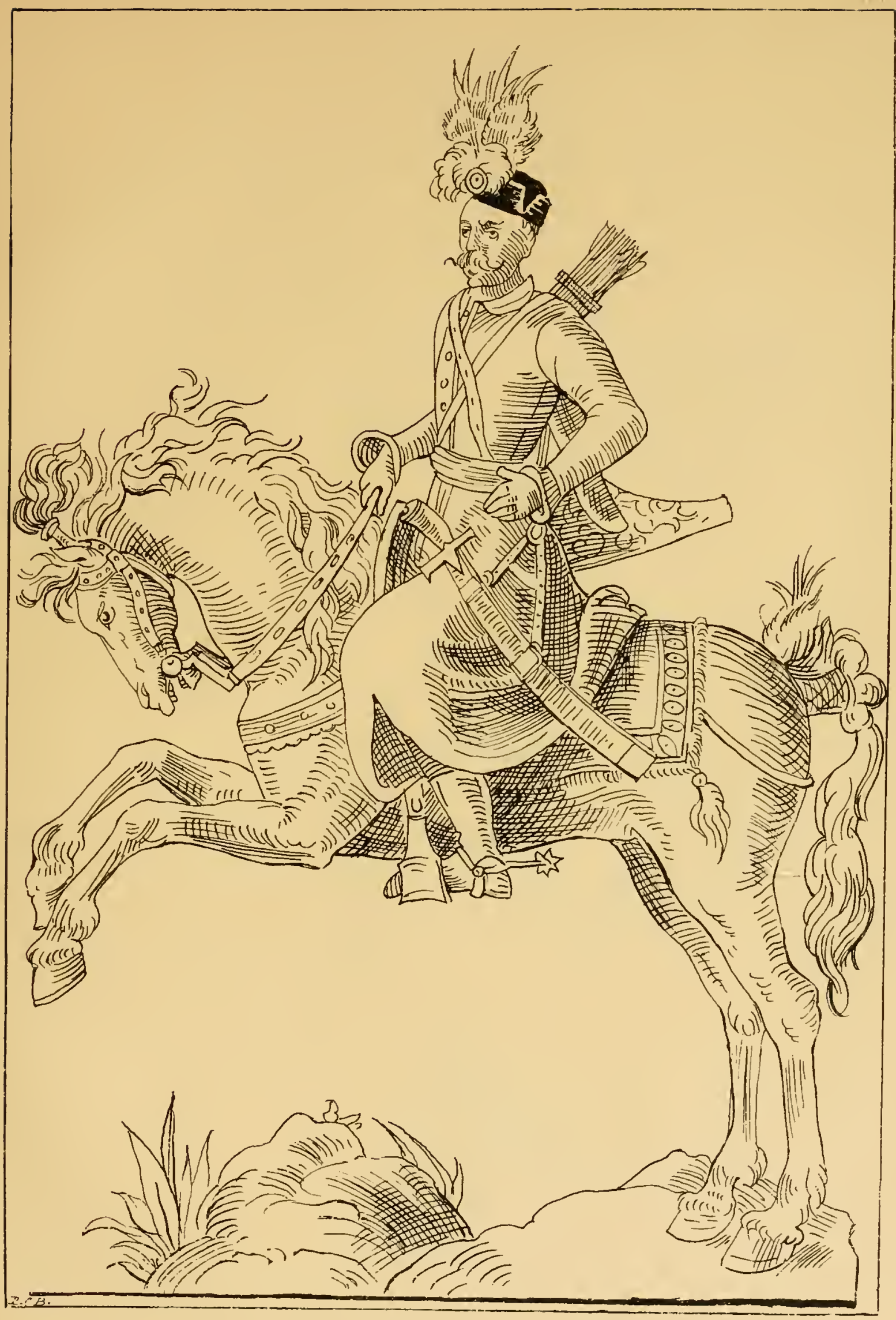





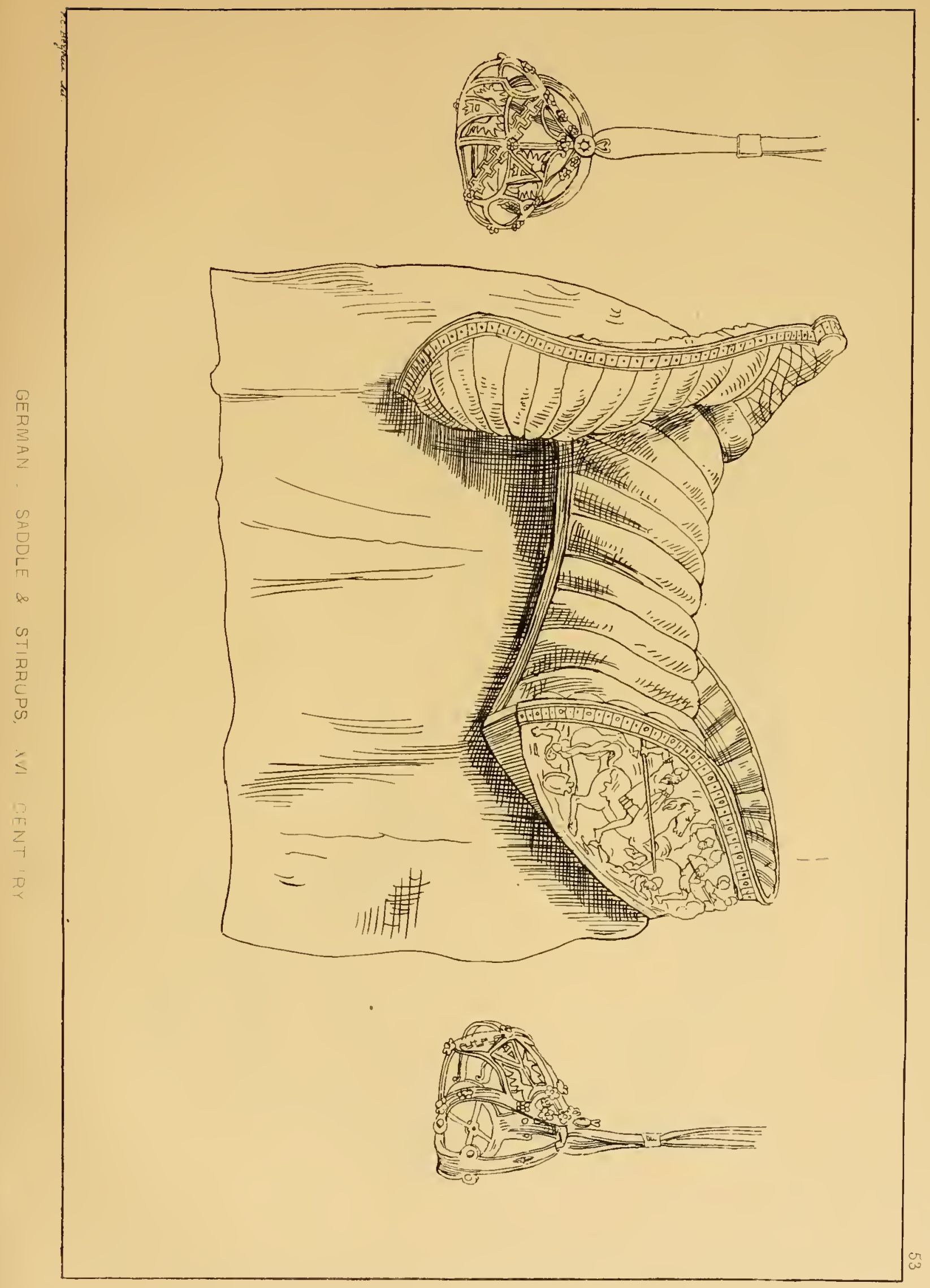





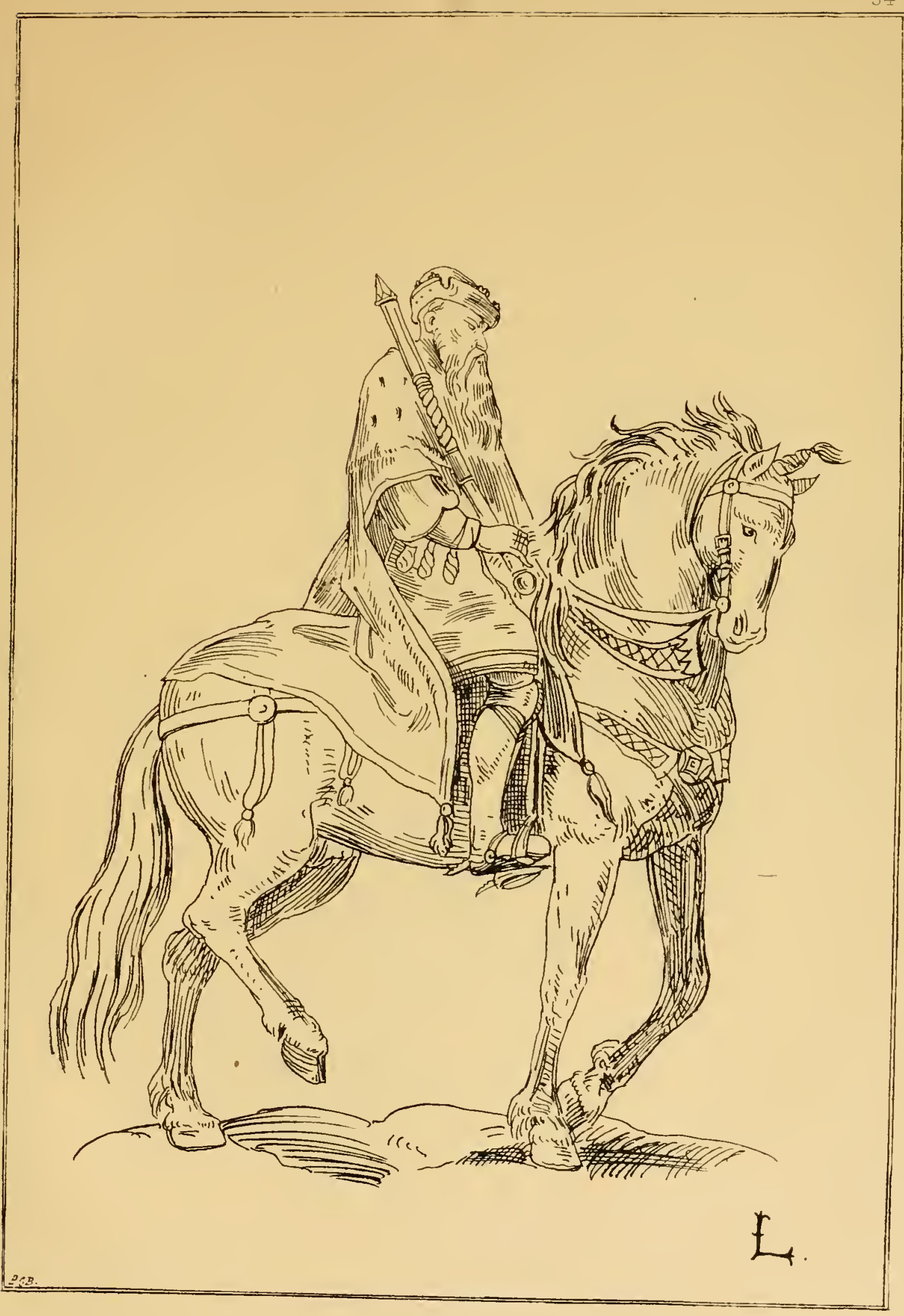





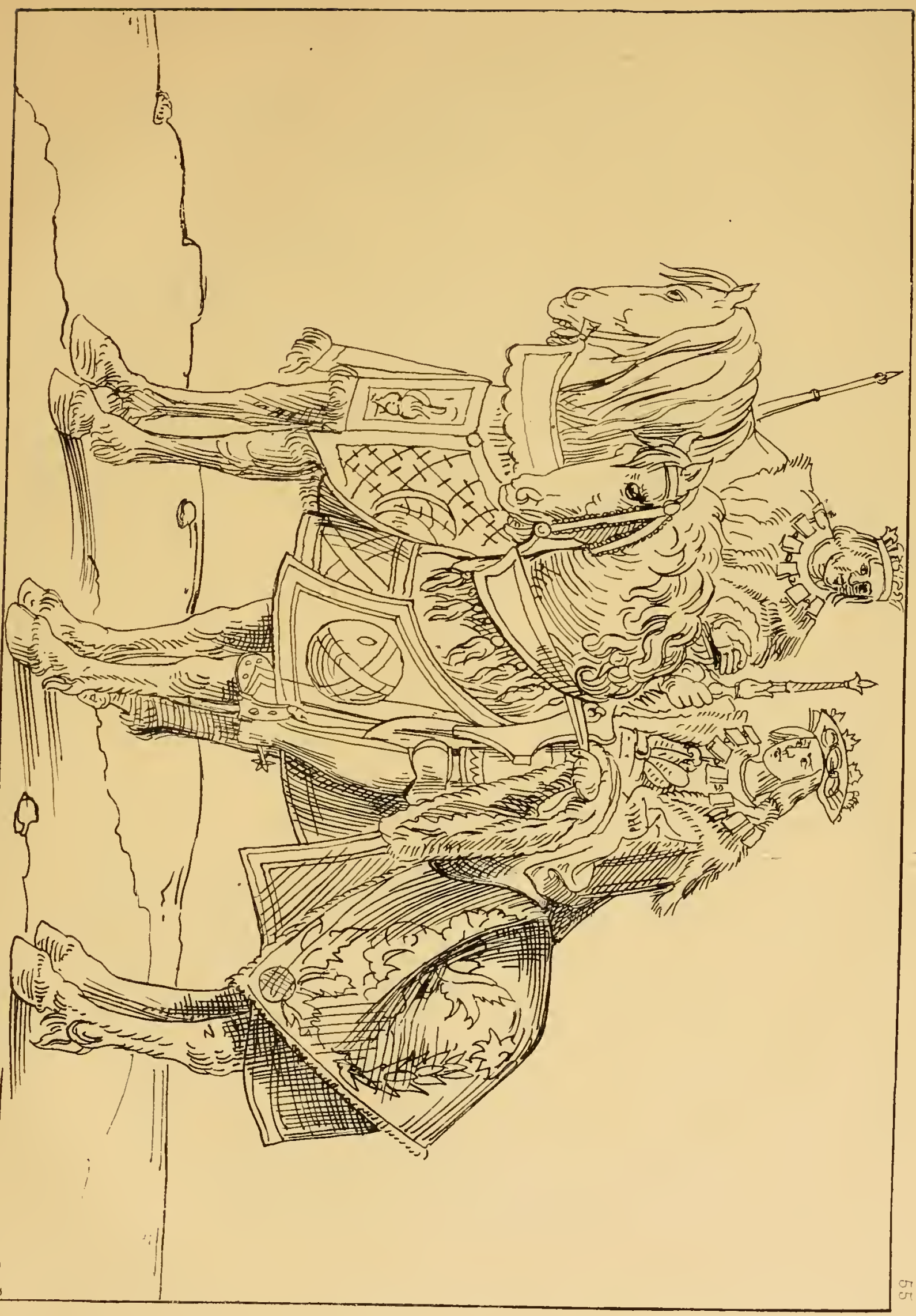





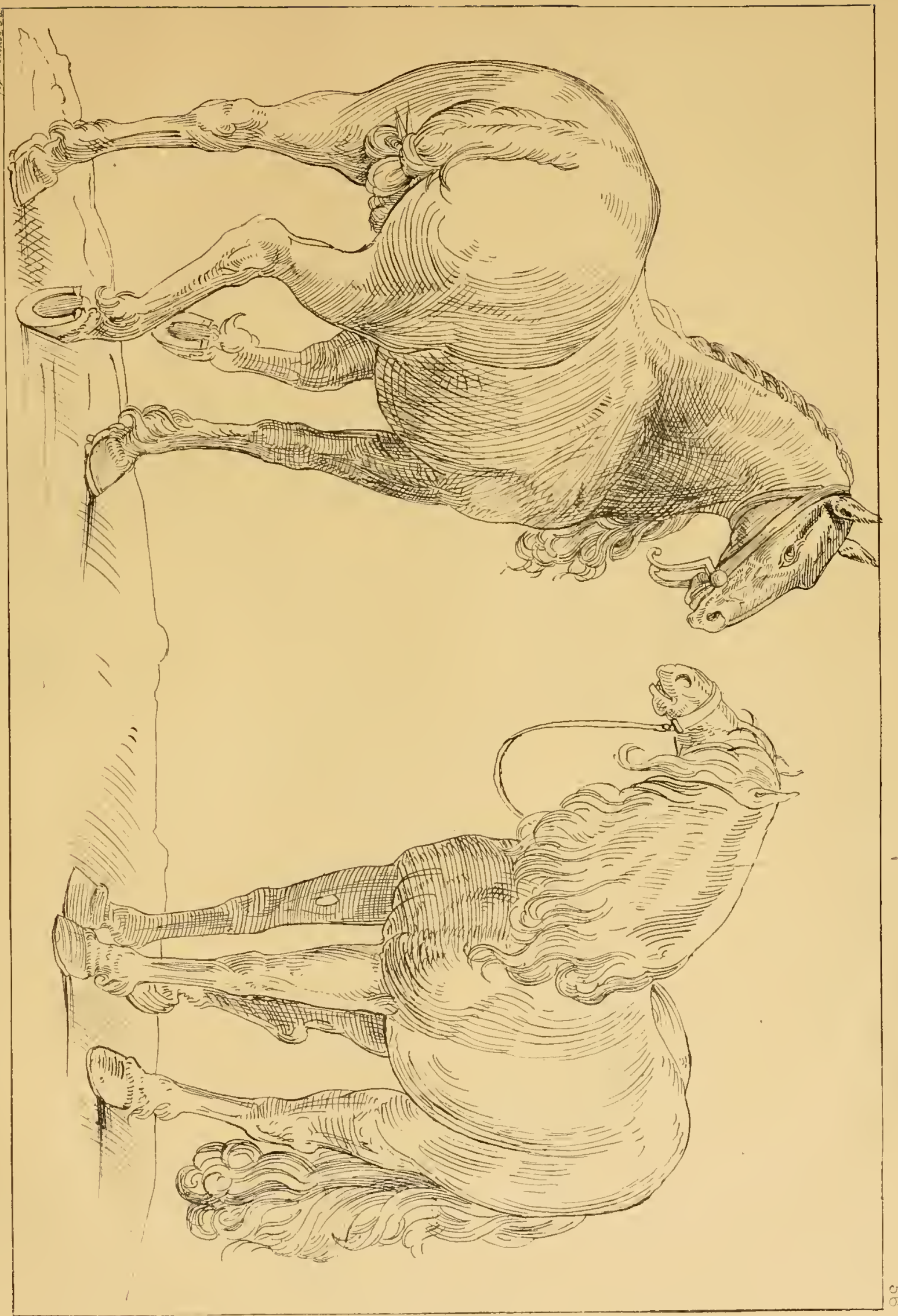





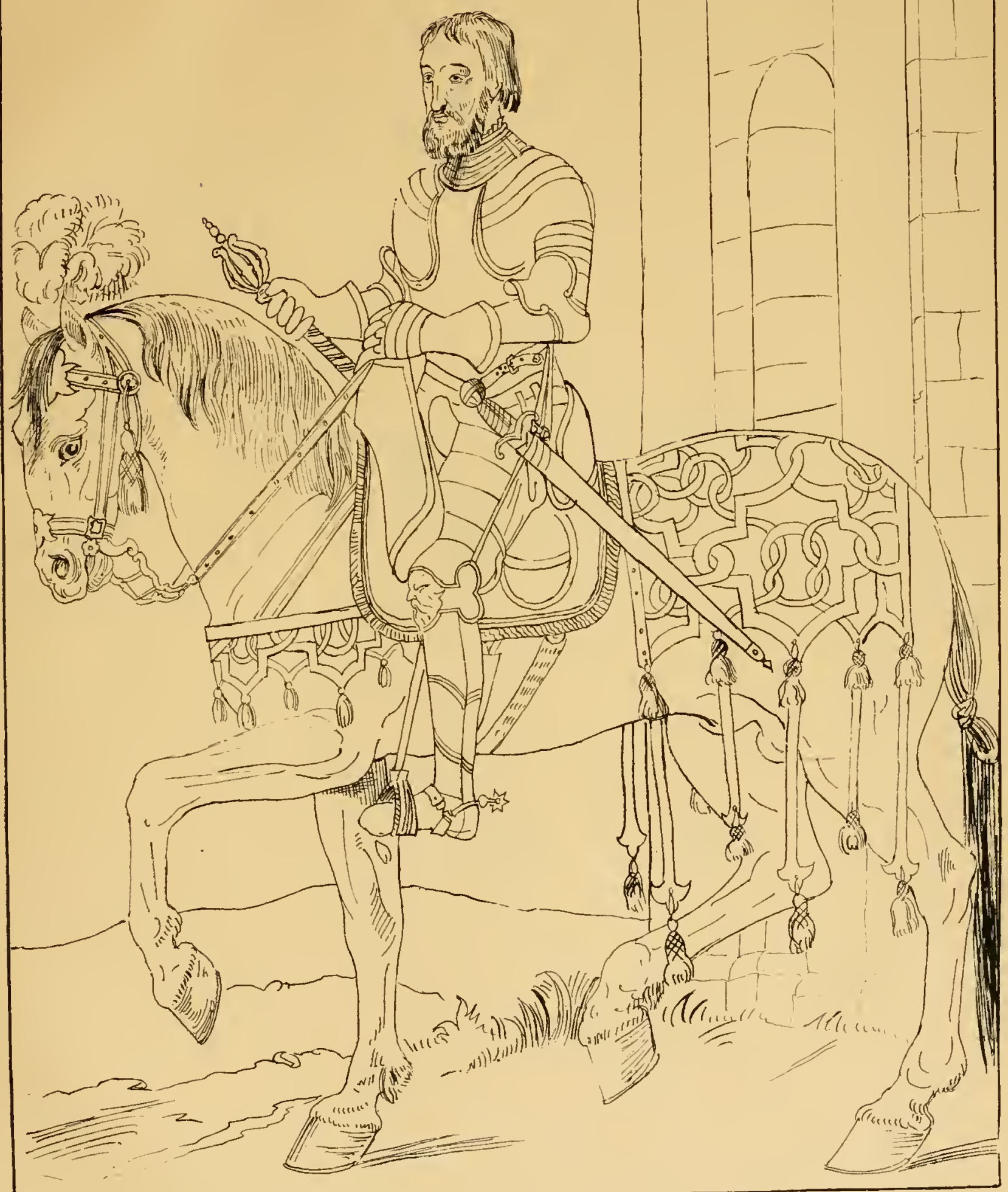





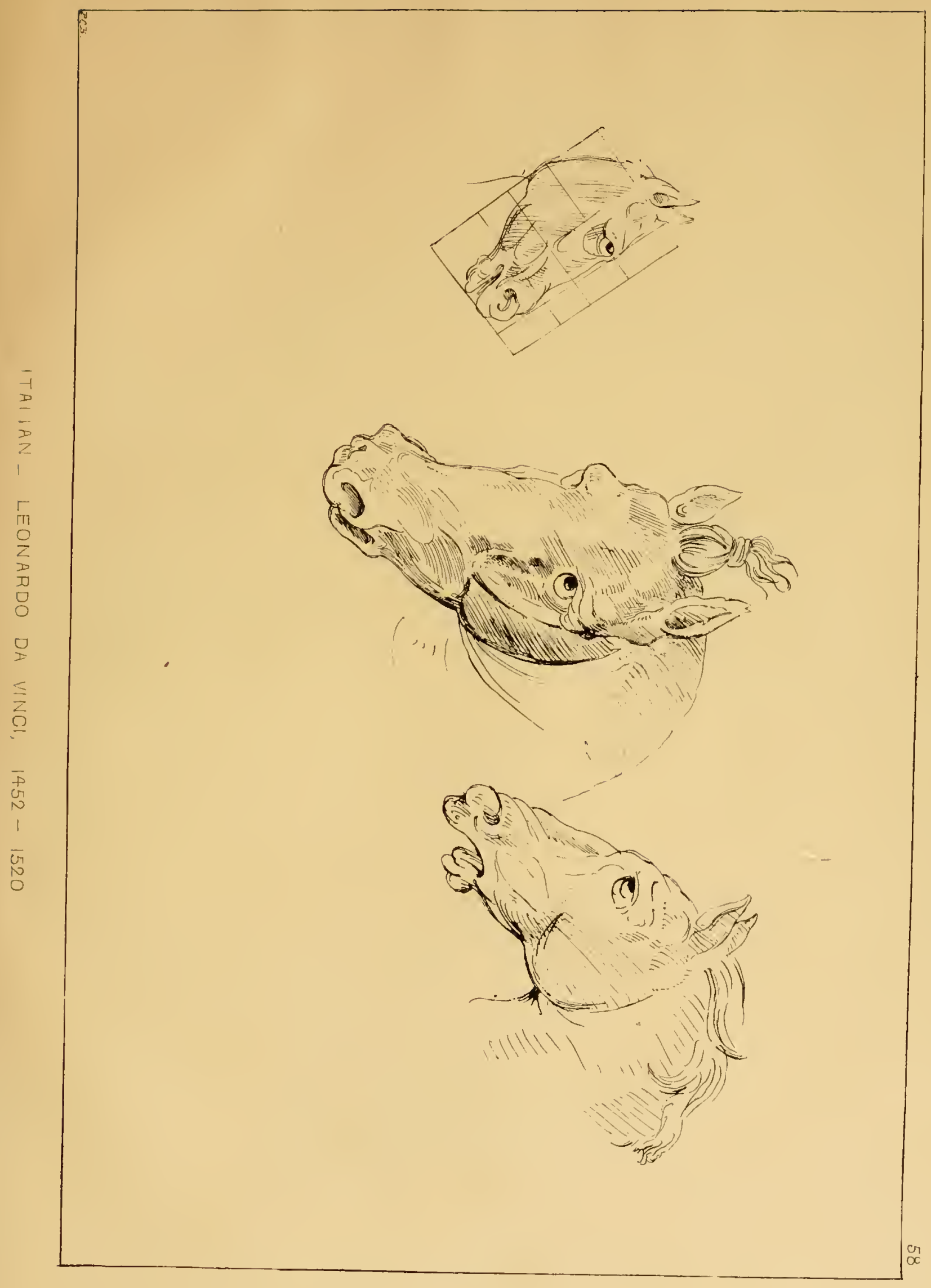





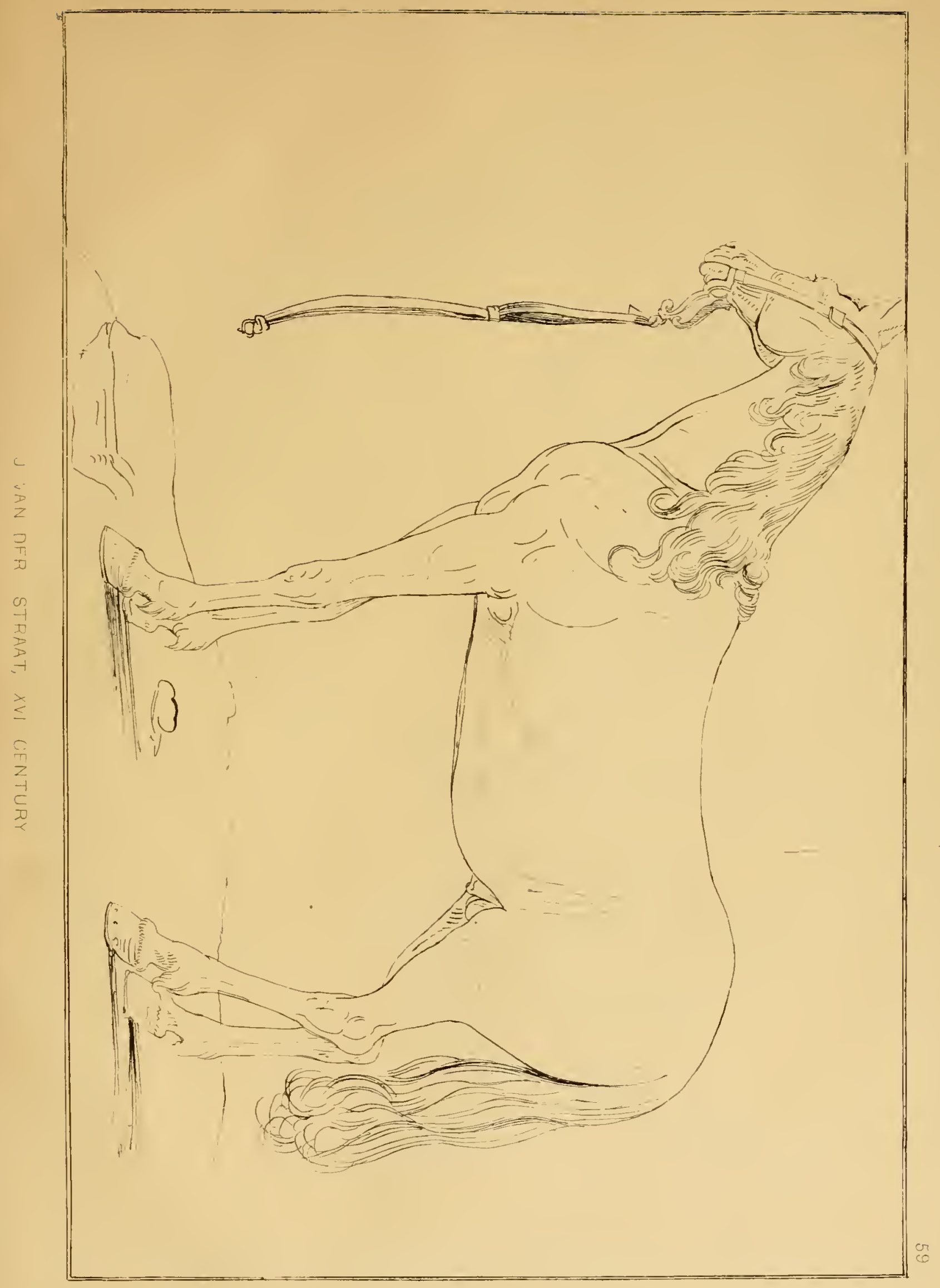




\section{.}




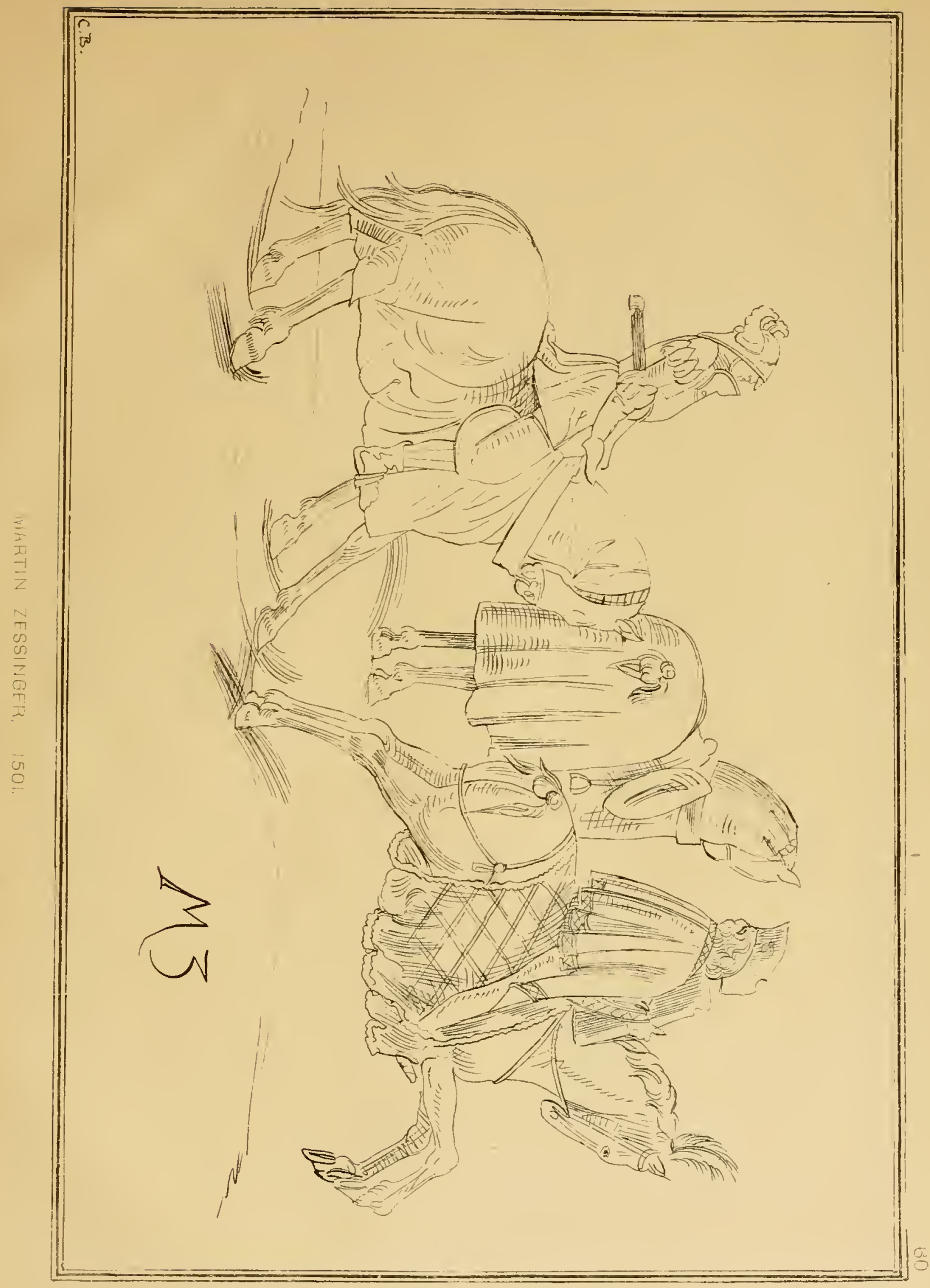





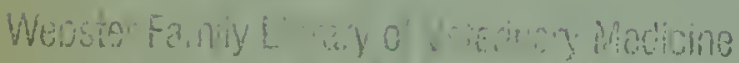

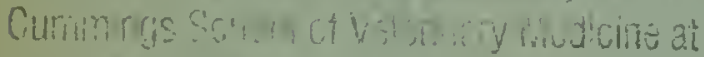
Tuts Urian y

200 Wosinoru Rnad

Norti Glaton. MA O1536 

